\title{
A Systematic Review (1990-2021) of Wild Animals Infected with Zoonotic Leishmania
}

\author{
Iris Azami-Conesa ${ }^{1}$, María Teresa Gómez-Muñoz ${ }^{1, * \mathbb{D}}$ and Rafael Alberto Martínez-Díaz ${ }^{2}$ \\ 1 Department of Animal Health, Faculty of Veterinary Sciences, University Complutense of Madrid, \\ 28040 Madrid, Spain; irisazami@ucm.es \\ 2 Department of Preventive Medicine and Public Health, and Microbiology, Faculty of Medicine, \\ University Autónoma of Madrid, 28029 Madrid, Spain; rafael.martinez@uam.es \\ * Correspondence: mariateg@ucm.es
}

Citation: Azami-Conesa, I.; Gómez-Muñoz, M.T.; Martínez-Díaz, R.A. A Systematic Review (1990-2021) of Wild Animals Infected with Zoonotic Leishmania. Microorganisms 2021, 9, 1101. https://doi.org/10.3390/ microorganisms 9051101

Academic Editor: David S. Lindsay

Received: 9 April 2021

Accepted: 14 May 2021

Published: 20 May 2021

Publisher's Note: MDPI stays neutral with regard to jurisdictional claims in published maps and institutional affiliations.

Copyright: (c) 2021 by the authors. Licensee MDPI, Basel, Switzerland. This article is an open access article distributed under the terms and conditions of the Creative Commons Attribution (CC BY) license (https:/ / creativecommons.org/licenses/by/ $4.0 /)$.

\begin{abstract}
Leishmaniasis are neglected diseases caused by several species of Leishmania that affect humans and many domestic and wild animals with a worldwide distribution. The objectives of this review are to identify wild animals naturally infected with zoonotic Leishmania species as well as the organs infected, methods employed for detection and percentage of infection. A literature search starting from 1990 was performed following the PRISMA methodology and 161 reports were included. One hundred and eighty-nine species from ten orders (i.e., Carnivora, Chiroptera, Cingulata, Didelphimorphia, Diprotodontia, Lagomorpha, Eulipotyphla, Pilosa, Primates and Rodentia) were reported to be infected, and a few animals were classified only at the genus level. An exhaustive list of species; diagnostic techniques, including PCR targets; infected organs; number of animals explored and percentage of positives are presented. L. infantum infection was described in 98 wild species and L. (Viania) spp. in 52 wild animals, while L. mexicana, L. amazonensis, L. major and L. tropica were described in fewer than 32 animals each. During the last decade, intense research revealed new hosts within Chiroptera and Lagomorpha. Carnivores and rodents were the most relevant hosts for L. infantum and L. (Viannia) spp., with some species showing lesions, although in most of the studies clinical signs were not reported.
\end{abstract}

Keywords: Leishmania; host; reservoir; wildlife; wild mammal; zoonoses; one health

\section{Introduction}

Included in the group known as neglected tropical diseases, the leishmaniases are a group of diseases caused by flagellated protozoan parasites from more than 20 species belonging to the genus Leishmania. The disease can appear with a variety of clinical pictures, depending on the species involved, the geographic region and the response of the host. Most people and animals infected by the parasite do not develop symptoms but, if present, the disease can follow three basic clinical forms in humans: cutaneous, mucocutaneous and visceral, while in animals, only cutaneous and/or visceral forms are observed. Leishmaniasis is a vector-borne disease transmitted by phlebotomine sand flies (order Diptera, family Psychodidae) with a worldwide distribution (Europe, Africa, the Americas, Asia, and one species recently described in Australia) and an endemic presence in more than 90 countries [1]. There are an estimated 350 million people at risk of Leishmania infection. The World Health Organization (WHO) estimates more than one million new cases per year in people around the world, making it one of the most relevant yet neglected parasitic diseases (https:/ / www.who.int/leishmaniasis/en/, accesed on 8 January 2021). Leishmaniasis is one of the leading causes of morbidity in the world among infectious diseases and one of the leading causes of death among tropical diseases [2]. The disease is present in 98 of the 200 countries that collaborate with the WHO, and information is regularly updated by the organisation [3]. At least 39 described species of Leishmania can be found in the literature, in addition to a significant number of informal or incomplete 
citations [4,5]. Many authors consider that some of these species should be synonymous and that the Leishmania taxonomy should be revised and simplified [6]. A list with the zoonotic species of the genus Leishmania along with their main characteristics is shown in Table 1.

Table 1. Zoonotic species of the genus Leishmania and their main characteristics (adapted from Ahoundi et al., 2016 and $2017[4,5])$.

\begin{tabular}{|c|c|c|c|c|}
\hline Section & Subgenus & Species & Clinical Disease in humans & Geographic Area \\
\hline \multirow[t]{16}{*}{ Euleishmania } & \multirow[t]{8}{*}{ Leishmania } & L. aethiopica & CL, DCL & Ethiopia, Kenya \\
\hline & & L. amazonensis & CL, DCL, MCL & Bolivia, Brazil and Venezuela \\
\hline & & L. donovani & VL, PKDL & $\begin{array}{c}\text { Central Africa, South Asia, Middle East, } \\
\text { India and China }\end{array}$ \\
\hline & & L. infantum & VL, CL & $\begin{array}{c}\text { North Africa, South Europe, Middle East, } \\
\text { Central Asia and North, Central and } \\
\text { South America }\end{array}$ \\
\hline & & L. major & CL & $\begin{array}{c}\text { Central and North Africa, Middle East } \\
\text { and Central Asia }\end{array}$ \\
\hline & & L. mexicana & CL, DCL & $\begin{array}{l}\text { USA, Mexico, Ecuador, Peru } \\
\text { and Venezuela }\end{array}$ \\
\hline & & L. tropica & CL, VL & $\begin{array}{l}\text { Central and North Africa, Middle East, } \\
\text { Central Asia and India }\end{array}$ \\
\hline & & L. venezuelensis & CL & Northern South America \\
\hline & \multirow[t]{8}{*}{ Viannia } & L. braziliensis & CL, MCL & $\begin{array}{l}\text { Brazil, Bolivia, Peru, Guatemala } \\
\text { and Venezuela }\end{array}$ \\
\hline & & L. guyanensis & $\mathrm{CL}, \mathrm{MCL}$ & $\begin{array}{l}\text { Bolivia, Brazil, French Guyana } \\
\text { and Suriname }\end{array}$ \\
\hline & & L. lainsoni & CL & Brazil, Bolivia and Peru \\
\hline & & L. lindenbergi & $\mathrm{CL}$ & Brazil \\
\hline & & L. naiffi & CL & Brazil, French Guyana \\
\hline & & L. panamensis & CL, MCL & Brazil, Panama, Venezuela and Colombia \\
\hline & & L. peruviana & CL, MCL & Peru, Bolivia \\
\hline & & L. shawi & $\mathrm{CL}$ & Brazil \\
\hline Paraleishmania & & L. colombiensis & CL, VL & Colombia \\
\hline
\end{tabular}

Zoonotic species included in the systematic review are in bold. Clinical forms in humans: CL: cutaneous leishmaniasis; DCL: Diffuse cutaneous leishmaniasis; VL: visceral leishmaniasis; MCL: muco-cutaneous leishmaniasis; PKDL: Post-kala-azar dermal leishmaniasis.

All species of the genus follow a biological cycle with the same pattern, alternating amastigote forms that replicate intracellularly in the vertebrate host, and promastigote forms that reproduce in the digestive system of the insect vector (Figure 1). Sand flies (mainly Phlebotomus and Lutzomya genera) become infected while feeding on a parasitised reservoir. Through the bite, they ingest macrophage-bearing blood and tissue with amastigotes. Natural vectors have been experimentally proven to be highly susceptible, and one or two parasites are sufficient to initiate an infection [7]. For a species of sand fly to be a vector of zoonotic Leishmania, it must meet five conditions: (1) be anthropophilic; (2) feed from reservoir hosts in cycles of zoonotic transmission; (3) be infected in nature with the same Leishmania species that infects humans; (4) harbour the complete development of the parasite until it becomes infective; (5) be capable of transmitting the parasite through the bite [8].

Other infectious routes, such as venereal and vertical transmission, have been proved for L. infantum in a canine host [9], and it is seriously considered in humans [10]. Biting is a route suspected for canids [11], and the oral route has been confirmed in hamsters [12], which has been suggested to be associated with the ingestion of micromammals by common genets and servals [13], or the ingestion of phlebotomines by insectivorous bats [14]. In another study, the presence of Leishmania amastigotes and promastigotes in the faeces of gorillas have been reported [15]. Indeed, translocation of bacteria from the gut to 
distant locations helped by dendritic cells is a phenomenon widely studied in the human microbiome nowadays $[16,17]$.

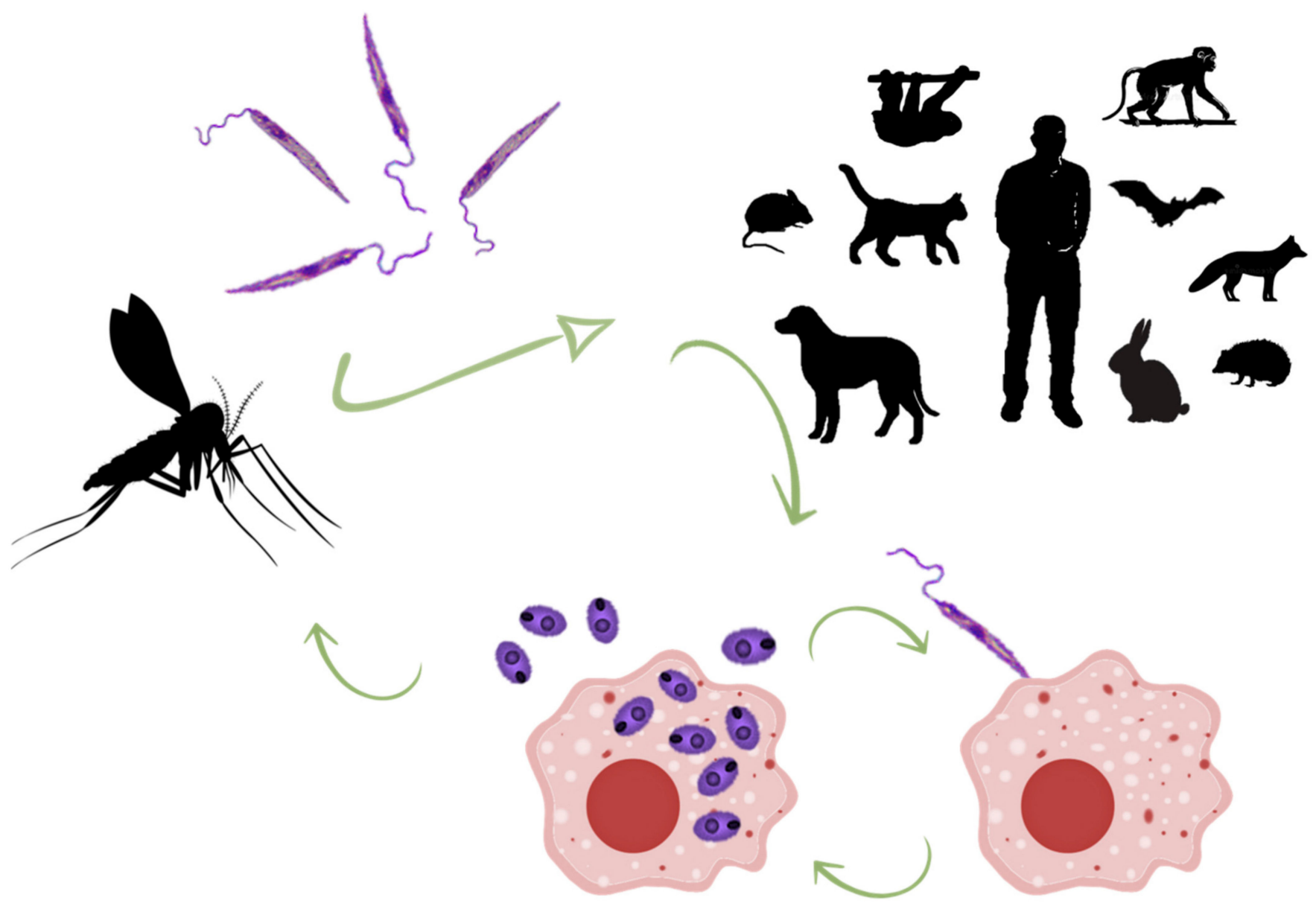

Figure 1. Life cycle of Leishmania: some of the wild animals found infected with the parasite are included.

A combination of strategies is required for the prevention and control of the disease, including early diagnosis and prompt and effective treatment, vector control, effective disease surveillance, control of animal reservoir hosts and social mobilisation and strengthening partnerships [18]. Domestic animals have been widely studied and, traditionally, dogs are considered the main animal reservoir, and cats and equines have been found in several studies infected with the parasite [19]. However, dogs were found with similar or even lower prevalence than wildlife during some human outbreaks, probably due to preventive measures applied [20,21]. For these reasons, the investigation of the role of wildlife in the infectivity and potential transmission of the parasite is an important step in order to control future outbreaks, and to monitor the endemicity of certain areas. A change in the factors influencing the abundance of vectors (i.e., deforestation, climatic change, and new urbanised areas), or the presence of potential animal reservoirs in a spatial and temporal coincidence with humans, are essential factors in the appearance of outbreaks.

According to the WHO [22], the term "reservoir" should be used only for animals that are sufficiently abundant and long-lived to be a food source for sand flies and that maintain intense contact with the sand fly vector in its environment. Several characteristics are necessary: (1) more than $20 \%$ of the specimens should be infected; (2) the course of infection should be long; (3) parasites should be available in the skin or blood in sufficient numbers to be taken up by the sand flies; (4) the parasites in the reservoirs and humans should be the same [23]. Reservoir hosts usually represent a large proportion of the mammalian biomass [23]. Roque and Jansen [24] applied the terms "maintenance hosts" 
for mammals than can be infected and maintain the infection and "amplifier hosts" for mammals that, besides maintaining the infection, may favour the transmission (for example with more parasites in the blood and skin for longer periods). In this context, many of the wild animals mentioned in this review could be considered as maintenance hosts that may serve as secondary reservoirs, if adequate conditions for disease dissemination are present, while only a few could be considered as amplifier hosts (i.e., animals proved to infect the vector or with high prevalence values and close proximity with humans).

This paper presents updated information on wildlife as potential reservoir hosts for all zoonotic Leishmania species, following a systematic review from 1990 to nowadays. Previous reviews should be examined for partial and prior information [19,23-27].

\section{Methods}

This systematic review was carried out following the Preferred Reporting Items for Systematic Reviews and Meta-Analyses (PRISMA) guidelines [28]. The main objective of this review was the identification of potential reservoirs of zoonotic species of Leishmania. Specific objectives were to (1) identify wild animal species naturally infected with zoonotic species of Leishmania; (2) recover information on the organs infected; (3) recover information on the techniques employed for detection and identification; (4) report data on the prevalence obtained in each study. These wild species should be investigated when an outbreak of leishmaniasis is present, or to monitor the endemicity of the disease in certain areas.

\subsection{Search Strategy and Databases}

Three databases were employed: PubMed (Medline), Scopus and Web of Science (WoS). The terms of search were "Leishmania" AND "wild" AND "host" OR "mammal". The information was retrieved from 1990 to 27 February 2021 and included only articles in English and zoonotic species of Leishmania (Table 1). Each author revised one database and eliminated reports according to the exclusion criteria. Duplicates were removed from the list before the employment of Mendeley to upload the selected articles. After the screening, the articles selected for inclusion were deeply analysed according to the species of Leishmania: Leishmania (Viannia) spp. were analysed by MTGM, Leishmania infantum was analysed by IAC and the rest of the species were analysed by RAMD. When doubts arose, the three authors discussed them and reached a consensus.

\subsection{Exclusion Criteria}

Automatic tools were employed to exclude some of the articles, while others were screened by the authors. Keywords for exclusion in Scopus were: animal experiment, animal model, mice, inbred C57BL, protozoan proteins, Bagg albino mouse, insect vectors, signal transduction, gene expression regulation, drug effect, inducible nitric oxide synthase, protein function, upregulation, wild type, macrophages, enzyme activity, mice knockout, cytokine production, Interleukin 10, Interleukin 4, mutant, mice inbred BALB C, unclassified drug, C57BL mouse, gene deletion, mutation, Th1 cell, cytokine, chemistry, Interleukin 12, protein expression, gamma interferon, arginase and CD4+T lymphocyte. Areas excluded in WoS were: research experimental medicine, virology, genetics heredity, biophysics, mycology, endocrinology metabolism, forestry, haematology, plant sciences, evolutionary biology, fisheries, oncology, physiology, polymer science and respiratory system.

Articles in Spanish, Portuguese, Turkish or French were excluded. Reviews, books and chapters of books, opinion articles, conference papers and letters were also excluded from the systematic review. Other criteria for exclusion were the following: experimental infections; clinical cases (except first citations); articles dealing with wild-type and genetically modified parasites; articles dealing only with human and/or domestic animals samples; articles dealing only with vectors or xenodiagnosis; articles dealing only with isolates obtained in previous studies; articles dealing only with phylogeny; studies with negative 
results to Leishmania infections; articles without enough information on the identification of Leishmania species; non-zoonotic species of Leishmania.

In total, 151 references were retrieved from the search of the databases, and ten more articles were found from other sources, and included (references from previous research articles and reviews) (Figure 2). All information contained in the tables was obtained from these articles, but additional references are included for the background. Recorded variables are included in the Supplementary Materials: host, number of animals sampled, organs analysed, method of detection, prevalence and geographic area.

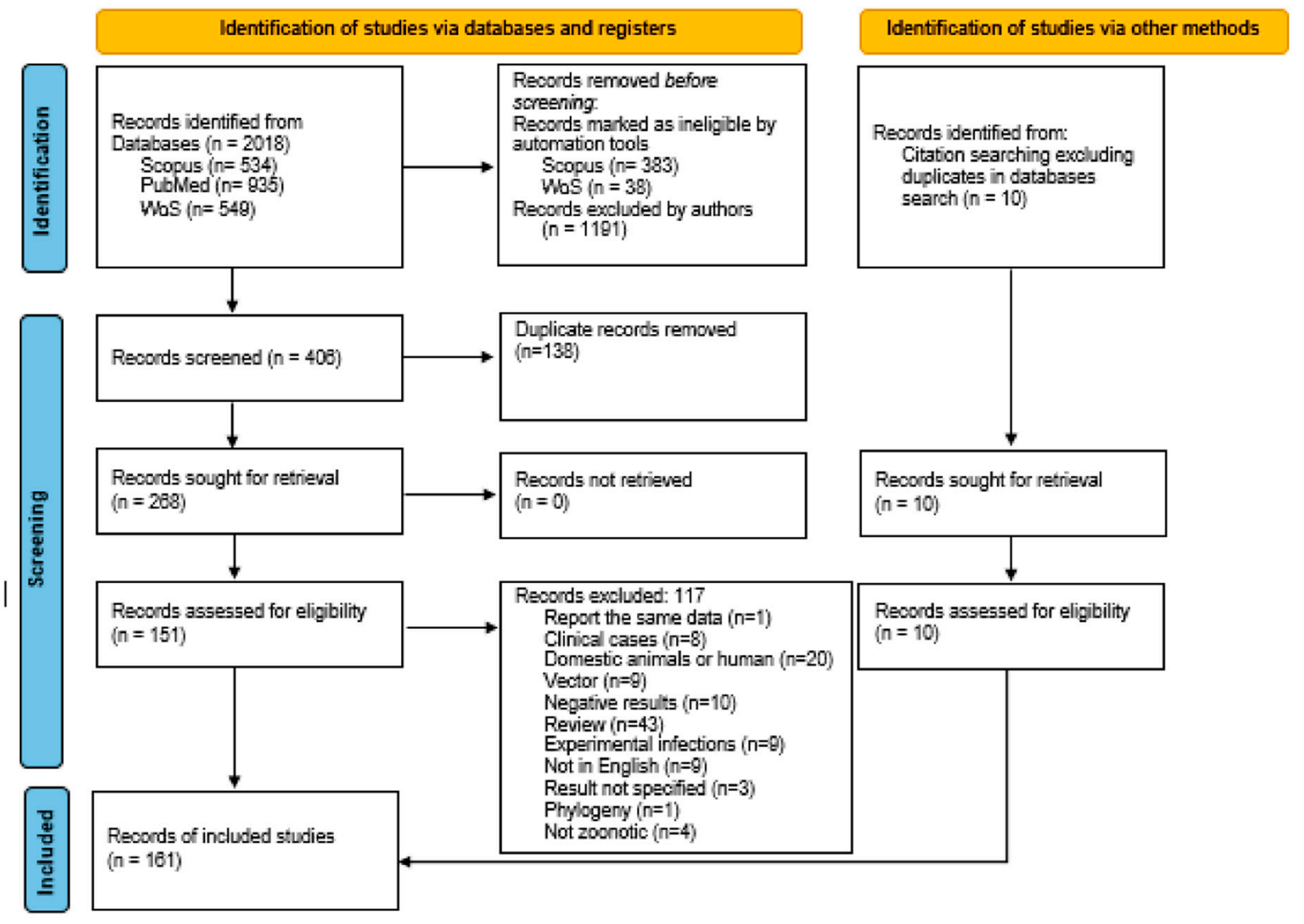

Figure 2. PRISMA 2020 flow diagram for the present systematic review.

Due to the variability found among the studies and taking into account that wild animals are not easy to sample, a meta-analysis was not conducted. The main objective of this review was to update the list of potential reservoirs of the parasite and, for that reason, even studies with only one animal of a certain species were included.

\section{Results}

\subsection{Result of the Search}

The database search identified 2018 records, 534 from Scopus, 935 from PubMed and 549 from WoS. After removal of articles by automation tools and by authors using title and abstract, duplicates were removed. Exclusion criteria were further applied and an outcome of 161 articles was reached: 151 articles retrieved from databases and ten from other sources (Figure 2).

\subsection{Wild Animals Infected with Zoonotic Leishmania (Viannia) spp.}

Among the species of Leishmania described in the Americas, L. braziliensis is one of the most widely investigated. L. (Viannia) braziliensis is the species more extensively distributed, and it has been described in Latin American countries, from Mexico to more 
southern countries. Data from wildlife include not only Brazil but also Venezuela, Colombia, Honduras, Belize, Peru, Panama and Argentina (Supplementary Materials File S1) [3,5]. Endemic leishmaniasis were present in several locations, such as the states of Sao Paulo and Minas Gerais in Brazil, especially where primary forest was substituted for human settlements [13]. Places such as coffee, banana or sugar cane plantations, ecotourism areas, or even chicken ruins and stables were known as breeding sites for the vector, and wild animals also became infected there [29-31]. Most of the studies were carried out in Brazil, especially in these endemic areas, whereas for other countries, such as Colombia, Peru, Bolivia, Venezuela or Argentina, infections were reported occasionally (Supplementary Materials File S1).

Blood and skin were the sites of detection in many of the published epidemiological works, since they are the most accessible for the hematophagous vector (Supplementary Materials File S1). However, when spleen, liver or bone marrow (BM) were included among the tissues analysed, prevalence rose, as the parasite tends to remain in these locations, even for species of Leishmania causing preferred cutaneous or mucocutaneous manifestations such as L. (Viannia) braziliensis or L. mexicana. Only one study employed oral swabs to successfully detect the DNA of the parasite [32].

Before the wide introduction of DNA amplification by PCR, fewer sensitive techniques were employed for the detection of Leishmania. Direct diagnosis of the parasite, such as examination of biopsies or imprints from skin or other organs, and culture in specific media were tested in rodents, marsupials and sloths in the past [24]. In fact, they are still being used in some studies today, although less frequently $[30,31,33,34]$. Serology has been extensively employed in domestic animals, but also in wildlife, as a sensitive and indirect evidence of Leishmania infection $[30,35,36]$, and is the preferred method when studying the presence of Leishmania in wild carnivores [37] (Supplementary Materials File S1). Xenodiagnosis by exploring transmission of the vector was rarely employed [29], although this approach could prove the reservoir character of the hosts. Finally, experimental infections of wild and synanthropic rodents and monkeys was an approach not frequently used and will not be treated here, because it is beyond the scope of this review [24].

Since PCR became a routine technique to detect Leishmania in tissues, the list of infected hosts has lengthened. Brandao-Filho et al. [30] compared three diagnostic tests with spleen samples from 203 animals (rodents and marsupials) and found kDNA PCR over three times more sensitive $(17.6 \%)$ than traditional methods such as microscopy of imprints $(5.7 \%)$ or culture $(1.3 \%)$. Serology seems to be less sensitive than molecular techniques, as it was shown for the prevalence of Leishmania in Didelphis marsupialis (8.1\% by serology vs. $20 \%$ by PCR) [38] and when small mammals were analysed (5\% serology vs. $8.8-23.2 \%$ by PCR) [39].

A vast number of primers, methods and targets for PCR detection can be found in the literature [5], but a few of them are widely employed in epidemiological studies in wildlife by several authors. Some targets are recognised as highly sensitive; this is the case for kinetoplast DNA (kDNA) which has more than 10,000 copies per cell [40]. PCR of kDNA has been employed for the detection of the parasite, followed by other approaches to determine the species of Leishmania present such as sequencing, RFLP or hybridisation (Supplementary Materials File S1). In some papers, the employment of PCR that amplify ITS1 or SSU allows also for the classification at the species level $[5,14]$.

Animals infected with zoonotic species of L. (Viannia) belong to the orders Carnivora, Cingulata, Chiroptera, Didelphimorphia, Lagomorpha, Pilosa, Primata and Rodentia, this last order being the most extensively studied.

Carnivores are usually blamed to be reservoirs of different species of Leishmania, and the scarce number of studies carried out revealed the presence of Leishmania (Viannia) spp. L. braziliensis DNAwas amplified by PCR in crab-eating dogs [34] and in Molina's hog-nose skunks, this last species being pointed out as a reservoir by the authors, since a strain was isolated from one animal [41]. Specific antibodies employing serological techniques, such as direct agglutination test (DAT), were found in high percentages in hoary foxes, 
ring-tailed coatis and crab-eating racoons (50-100\%), but the authors tested a small number of the animals for each species [37] (for details, see Supplementary Materials File S1).

The number of studies exploring the presence of Leishmania in bats has increased since 2013, when Shapiro et al. found DNA of the parasite in blood, liver and skin by PCR [42]. Since then, four more studies found L. (Viannia) spp. DNA in more than eight species of bats including hematophagous, insectivorous and frugivorous individuals [32,43-45].

Armadillos (order Cingulata) have been examined for Leishmania infection and found positive by PCR and culture plus zymodeme analysis in blood, spleen and liver [46] and in another study by PCR of the kDNA region, but the species of Leishmania present were not further investigated [34]. Regarding Lagomorpha, only one study demonstrated the presence of L. braziliensis in tapetis (Sylvvilagus braziliensis) in Colombia, employing xenodiagnosis and PCR followed by hybridisation [29] (Supplementary Materials File S1).

The presence of L. braziliensis has previously been reported in sloths, rodents and marsupials, and the reservoir character of these groups has been shown by several authors in the past $[13,23]$. The order Didelphimorphia, especially the white-eared opossum (Didelphis albiventris), was the focus of at least sixteen studies employing diverse PCRs, culture and serology, with highly variables percentages of infection [21,29,30,34,37-39,47-55] (Supplementary Materials File S1). In addition, xenodiagnosis was successful in this species as well as in the woolly-mouse opossum (Micoureus demerarae), which reinforces their role as main reservoirs of leishmaniasis [29,48]. One study found three two-toed-sloths (Choloepus hoffmani) infected with L. panamensis in Panama [56].

Rodents are the group most widely explored regarding Leishmania infections, both in natural and experimental conditions. The presence of L. braziliensis and other zoonotic species of the subgenus Viannia has been reported in 27 species including Rattus rattus, Cerradomys subflavus, Necromys lasiurus, Nectomys squamipes and Mus musculus, the latter being the species more often investigated [21,29-31,33-37,39,47,49,50,53,55,57-63] (Supplementary Materials File S1). This may be due to the fact of several reasons: their probable role as relevant reservoirs of leishmaniasis for humans, their proximity and high prevalence values (rats and domestic mouse), their abundance in ecological niches where phlebotomines reproduce, or to the successful attempts when xenodiagnosis or strain isolation were employed. Prevalence values varied from $1.2 \%$ to $100 \%$ depending on the sampling area, the sample size, the organs analysed, the diagnostic procedures employed for detection and characterisation and, probably, also on the age and lifespan of the sampled animals. Xenodiagnosis was successful in synanthropic species, such as black rats, and wild species, such as Melanomys caliginosus and Mycroryzomys minutus. The parasite was isolated by culture from Akodon spp., Agouti paca, C. subflavus, N. lasiurus, R. rattus and Sigmodon hispidus, but the PCR of kDNA was the preferred method for detection. When RFLP or sequencing was applied after PCR, the species could be determined, being L. braziliensis and L. guyanensi the most frequent. L. naiffi, L. shawi and L. lainsoni were obtained from rodents. Minor zoonotic species, such L. shawi and L. naiffi, were detected in species of the genus Trichomys [36], and L. lainsoni was mainly found in the big rodent paca (Agouti paca) [57] (Supplementary Materials File S1). Less frequent species of Leishmania, such as L. peruviana, were obtained from rodents and Didelphimorphia in Peru [47].

Only four studies were performed on primates employing PCR of KDNA, miniexon or ITS regions, some followed by sequencing or RFLP $[34,37,64,65]$, while DAT was only employed in one study. Leishmania (Viannia) spp. was found between $8.6-100 \%$ of the animals analysed, with L. braziliensis being present, when identified to the species level [37].

All these investigations are summarized in Table 2. 


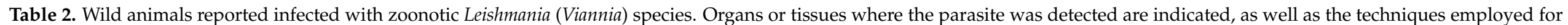

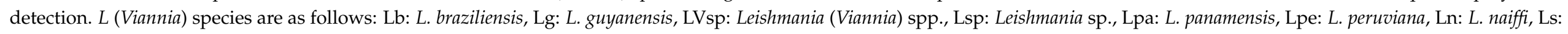
L. shawi and Ll: L. lainsoni.

\begin{tabular}{|c|c|c|c|c|c|c|}
\hline Host & Prevalence & Organs/Tissue Analysed & Methods for Detection & $\begin{array}{c}\text { Leishmania } \\
\text { (Viannia) species }\end{array}$ & Country & References \\
\hline \multicolumn{7}{|l|}{ Order Carnivora } \\
\hline Cerdocyon thous (crab-eating fox) & $20-100 \%$ & blood, serum & PCR (kDNA), DAT & LVsp & Brazil & {$[34,37]$} \\
\hline $\begin{array}{c}\text { Conepatus chinga rex (Molina's } \\
\text { hog-nose skunk) }\end{array}$ & $50 \%$ & Skin + liver + spleen & $\begin{array}{l}\text { Inoculation to hamster, isoenzyme } \\
\text { analysis, hybridisation, PCR (kDNA) }\end{array}$ & $\mathrm{Lb}$ & Bolivia & {$[41]$} \\
\hline $\begin{array}{l}\text { Lycalopex (Pseudalopex) vetulus } \\
\text { (hoary fox) }\end{array}$ & $100 \%$ & serum & DAT & LVsp & Brazil & [37] \\
\hline Nasua nasua (ring-tailed coati) & $50 \%$ & serum & DAT & LVsp & Brazil & [37] \\
\hline $\begin{array}{l}\text { Procyon cancrivorous } \\
\text { (crab-eating raccoon) }\end{array}$ & $50 \%$ & serum & DAT & LVsp & Brazil & [37] \\
\hline \multicolumn{7}{|l|}{ Order Cingulata } \\
\hline Dasypus novemcinctus (armadillo) & $15.6 \%$ & blood, LN, liver, skin, spleen & Culture, zymodeme analysis & $\mathrm{Lb}$ & Brazil & [46] \\
\hline Dasypus sp. & $100 \%$ & blood & PCR (kDNA) & LVsp & Brazil & {$[34]$} \\
\hline \multicolumn{7}{|l|}{ Order Chiroptera } \\
\hline Artibeus planirostris (frugivorous) & $4.3 \%$ & skin & $\begin{array}{c}\text { PCR (kDNA), PCR (HSP70) + RFLP, } \\
\text { PCR (G6DP) + sequencing }\end{array}$ & $\mathrm{Lb}$ & Brazil & {$[43]$} \\
\hline Desmodus rotundus (hematophagous) & $3.2 \%$ & blood & PCR (kDNA), PCR (Cyt B) + sequencing & $\mathrm{Lb}$ & Brazil & [43] \\
\hline Eumops perotis (insectivorous) & $5.6 \%$ & blood & PCR (kDNA), PCR (Cyt B) + sequencing & $\mathrm{Lb}$ & Brazil & {$[45]$} \\
\hline Glossophaga soricina (insectivorous) & $0.9-40 \%$ & blood, liver, spleen & $\begin{array}{c}\text { PCR (ITS1) + RFLP, PCR (kDNA, PCR } \\
\text { (Cyt B) + sequencing }\end{array}$ & $\mathrm{Lb}$ & Brazil & {$[42,44,45]$} \\
\hline Lasiurus cinereus (insectivorous) & $20 \%$ & liver, skin & PCR (kDNA), nPCR (SSU) + sequencing & Lb, LVsp & Brazil & {$[44]$} \\
\hline Molossus molossus (insectivorous) & $44-25 \%$ & blood & $\begin{array}{c}\text { PCR (ITS1) + RFLP, PCR (kDNA), PCR } \\
\text { (Cyt b) + sequencing }\end{array}$ & $\mathrm{Lb}$ & Brazil & {$[42,45]$} \\
\hline Platyrrhinus lineatus (frugivorous) & $13.3 \%$ & skin & $\begin{array}{l}\text { PCR (kDNA), PCR (HSP70) + RFLP, } \\
\text { PCR (G6DP) + sequencing }\end{array}$ & $\mathrm{Lb}$ & Brazil & [43] \\
\hline $\begin{array}{l}\text { Several species: Artibeus lituratus, } \\
\text { Carollia perspicillata, Diphylla ecaudata } \\
\text { and Glossophaga soricina) }\end{array}$ & $19.8 \%$ & oral swab & PCR (SSU) + sequencing & LVsp & Brazil & [32] \\
\hline
\end{tabular}


Table 2. Cont

\begin{tabular}{|c|c|c|c|c|c|c|}
\hline Host & Prevalence & Organs/Tissue Analysed & Methods for Detection & $\begin{array}{c}\text { Leishmania } \\
\text { (Viannia) species }\end{array}$ & Country & References \\
\hline \multicolumn{7}{|l|}{ Order Didelphimorphia } \\
\hline $\begin{array}{c}\text { Didelphis albiventris } \\
\text { (white-eared opossum) }\end{array}$ & $1.6-50 \%$ & $\begin{array}{l}\text { blood, BM, liver, serum, skin } \\
\text { (tail/ear), spleen }\end{array}$ & $\begin{array}{c}\text { culture, imprints, isoenzymes, PCR } \\
\text { (kDNA), qPCR (kDNA) PCR (ITS1), } \\
\text { PCR (HSP70), PCR (HSP70) + RFLP, } \\
\text { PCR (ITS) + RFLP, nPCR (SSU) + } \\
\text { sequencing, IFAT, DAT }\end{array}$ & Lb, LVsp, Lg, Lpe & Peru, Brazil & $\begin{array}{c}{[21,30,37-} \\
39,47,50-54]\end{array}$ \\
\hline $\begin{array}{l}\text { Didelphis marsupialis } \\
\text { (common opossum) }\end{array}$ & $20-33.3 \%$ & ear & $\begin{array}{l}\text { PCR (kDNA), hybridisation, } \\
\text { xenodiagnoses vector }\end{array}$ & $\mathrm{Lb}, \mathrm{LVsp}$ & Colombia & {$[29,49]$} \\
\hline Didelphis sp. & $90 \%$ & blood & PCR (kDNA), culture & LVsp & Brazil & [34] \\
\hline Marmosa sp. & $16.7-25 \%$ & skin, spleen & PCR (kDNA), smears, culture & LVsp & Brazil & {$[30,39]$} \\
\hline $\begin{array}{l}\text { Gracilinanus agilis (agile } \\
\text { gracile opossum) }\end{array}$ & $1.4-75 \%$ & $\begin{array}{l}\text { blood, BM, liver, skin } \\
\text { (tail/ear), spleen }\end{array}$ & $\begin{array}{l}\text { PCR (kDNA), PCR (HSP70), PCR } \\
\text { (HSP70) + RFLP, PCR (ITS) + RFLP }\end{array}$ & Lb, LVsp, Lg & Brazil & {$[21,55]$} \\
\hline $\begin{array}{l}\text { Marmosops incanus (grey } \\
\text { slender opossum) }\end{array}$ & $50 \%$ & ear skin & PCR $($ HSP70 $)+$ RFLP & & Brazil & {$[21]$} \\
\hline $\begin{array}{l}\text { Micoureus demerarae (woolly } \\
\text { mouse opossum) }\end{array}$ & $66.7 \%$ & ear & $\begin{array}{l}\text { PCR (kDNA), hybridisation, } \\
\text { xenodiagnoses vector }\end{array}$ & $\mathrm{Lb}$ & Colombia & [29] \\
\hline Micoureus sp. & $100 \%$ & blood & PCR (kDNA) & LVsp or Lsp. & Brazil & [34] \\
\hline \multicolumn{7}{|l|}{ Order Lagomorpha } \\
\hline Sylvilagus brasiliensis (tapeti) & $100 \%(n=1)$ & ear & $\begin{array}{l}\text { PCR (kDNA), hybridisation, } \\
\text { xenodiagnoses vector }\end{array}$ & $\mathrm{Lb}$ & Colombia & [29] \\
\hline \multicolumn{7}{|l|}{ Order Pilosa } \\
\hline Choloepus hoffmani (two-toed sloth) & $75 \%$ & blood & Culture, PCR (kDNA), PCR (HSP70) & Lpa & Panama & [56] \\
\hline \multicolumn{7}{|l|}{ Order Primates } \\
\hline Alouatta caraya (black howler) & $8.3 \%$ & ear tissue & PCR (ITS) + RFLP + sequencing & Lb, LVsp & Argentina & [64] \\
\hline Aotus azarai (Azara's night monkey) & $44.4 \%$ & blood, spleen & PCR (miniexon) + RFLP + sequencing & $\mathrm{Lb}$ & Argentina & [65] \\
\hline Callithrix sp. & $100 \%$ & blood & PCR (kDNA) & LVsp & Brazil & [34] \\
\hline Cebus apella (tufted capuchin) & $100 \%$ & serum & DAT & LVsp & Brazil & [37] \\
\hline
\end{tabular}


Table 2. Cont.

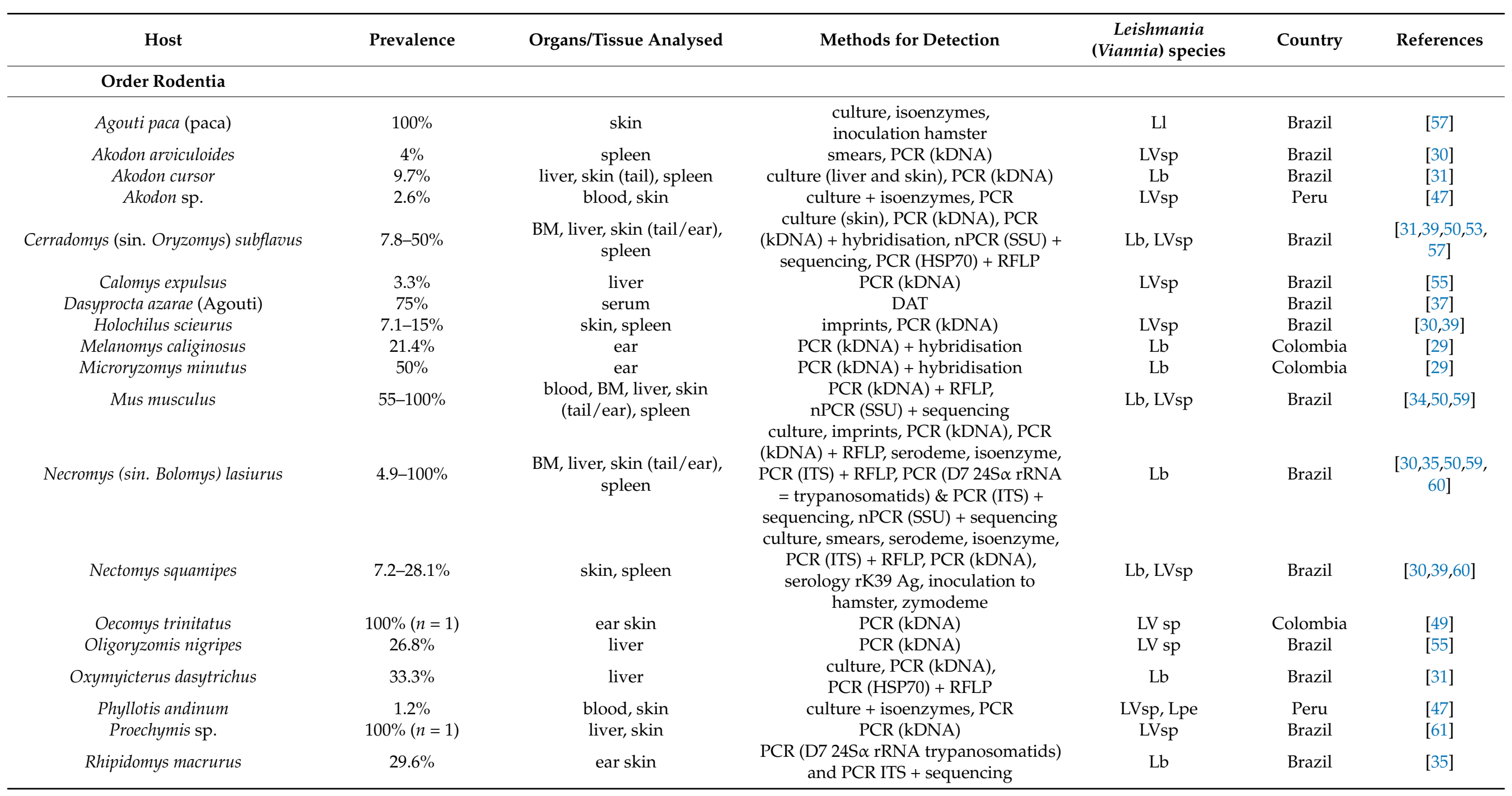


Table 2. Cont.

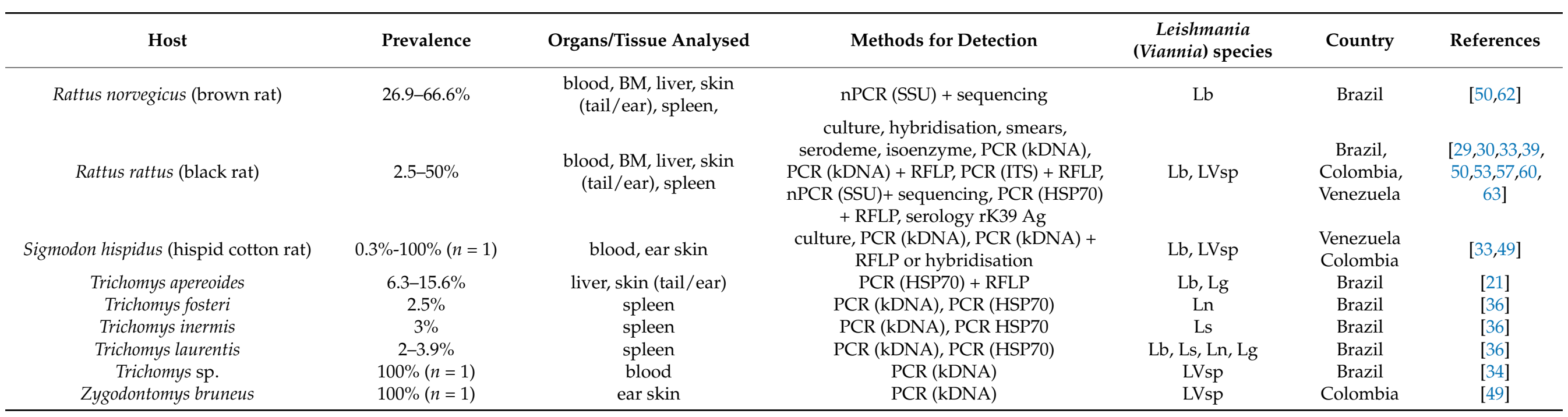

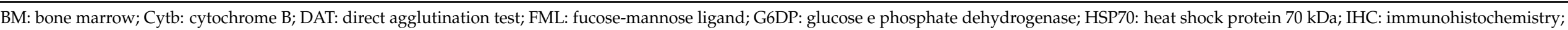

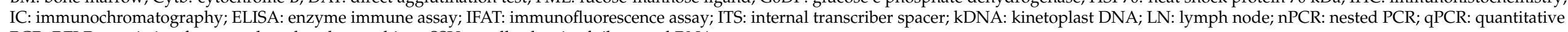
PCR; RFLP: restriction fragment length polymorphism; SSU: small subunit of ribosomal RNA. 
In previous reviews $[23,24]$, other species of wild animals were found infected with Leishmania (Viannia) spp., such as rodents (Coendu sp., Rhipidomys leucodactylus, Heteromys dermarestianus, Proechymis semispinosus, Trichomys pachyurus), sloths (Choleopus didactylus, Bradypus infuscatus, Bradypus tridactylus), anteanters (Tamandua tetradactyla), primates (Aotus trivirgatus, Cebus apella, Chiropotes satanas, Sanguinus geoffroyi) and carnivores (Nasua nasua, Potos flavus). For more details, see previous articles dealing with leishmaniasis in the Americas [23,24].

\subsection{Wild Animals Infected with Leishmania amazonensis}

L. amazonensis was described in countries from Central and South America, where data were available, including Costa Rica, Panama, Venezuela, Colombia, Ecuador, Peru, Argentina, Uruguay, French Guiana, Surinam, Brazil and Bolivia, the last two countries being the most widely studied $[3,5]$. This review includes updated information of wild animals infected with the parasite from surveys carried out in Brazil, Bolivia and Argentina.

Among carnivores, L. amazonensis was detected only in one of two skunks analysed from a focus of leishmaniasis in Bolivia [41]. More information was retrieved from three studies including several species of bats $[14,45,66]$. Most of the species analysed were insectivorous bats, but the parasite was also detected in hematophagous (Desmodus rotundus), nectarivorous and omnivorous species. Prevalence values varied from $1 \%$ to $25 \%$, probably depending on the geographic area, the species and the organs or techniques employed for detection. Higher values were observed in Sturnira lilium and Eumops auripendulus from urban areas and remnants of primitive forest of Sao Paulo (Brazil), employing nested PCR from liver and spleen (Supplementary Materials File S2).

Primates and opossum have been scarcely reported with L. amazonensis in the last 30 years, but the species was recently detected by PCR of the ITS region in the ear tissue of $2.8 \%$ of 209 black howler monkeys (Alouatta caraya) from Argentina [64]. In addition, a clinical case of a spider monkey (Ateles paniscus) from a zoo in Brazil, which showed weight loss and pale mucous membranes, was further confirmed by PCR and RFLP from blood [67]. L amazonensis DNA was also detected in 1.1\% of the analysed woolly-mouse opossum (Marmosa paraguayanus) from Brazil [48] (Supplementary Materials File S2).

Three studies from Bolivia and Brazil reported the presence of L. amazonensis in blood or skin (tail or ear) by PCR followed by sequencing, in 7.1-33.3\% of the analysed rodents (Hylaeamys, Oryzomys, Akodon, Necromys and Olygoryzomis genera) $[35,41,68]$. Some of these rodents displayed old lesions including scars on the tail or ear [68].

Animals found infected with L. amazonensis, as weel as the techniues employed, are summarized in Table 3.

Further information on other species infected with L. amazonensis can be found in previous reviews [23,24], and include rodents (Dasyprocta spp., Oligoryzomis spp., Orzyomis melanotis, Proechymis spp., Trichomys apereoides, Sciurus vulgaris), carnivores (Cerdocyon thous, Potos flavus), anteaters (Tamandua tetradactyla), marsupials (Didelphis marsupialis, Metachirus nudicaudatus, Philander opossum and Marmosa cinerea) and primates (Saguinus geoffroyi). 


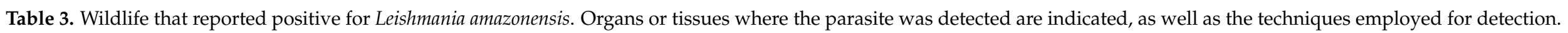

\begin{tabular}{|c|c|c|c|c|c|}
\hline Host & Prevalence & Organs/Tissue Analysed & Methods for Detection & Country & Reference \\
\hline \multicolumn{6}{|l|}{ Order Carnivora } \\
\hline Conepatus chinga rex (Molina's hog-nose skunk) & $50 \%$ & liver, skin and spleen & $\begin{array}{c}\text { Inoculation to hamster, Isoenzyme typing, PCR (kDNA) PCR } \\
\text { (trypanosomatids) + hybridisation }\end{array}$ & Bolivia & [41] \\
\hline \multicolumn{6}{|l|}{ Order Chiroptera } \\
\hline Artibeus lituratus (nectarivorous) & $1.6 \%$ & liver, skin and spleen & nPCR (SSU), qPCR (kDNA), PCR (ITS1) + RFLP & Brazil & {$[14,66]$} \\
\hline Artibeus planirostris (nectarivorous) & n.s. & skin & gPCR (kDNA), PCR (ITS1) + RFLP & Brazil & [14] \\
\hline Desmodus rotundus (haematofagous) & n.s. & liver, spleen & qPCR (kDNA), PCR (ITS1) + RFLP & Brazil & [14] \\
\hline Eumops glaucinus (insectivorous) & $8.3 \%$ & liver, skin and spleen & nPCR (SSU), qPCR (kDNA), PCR (ITS1) + RFLP & Brazil & {$[14,66]$} \\
\hline Eumops perotis (insectivorous) & $5.6 \%$ & blood & PCR (kDNA), PCR (Cyt b) + sequencing & Brazil & [45] \\
\hline Glossophaga soricina (insectivorous) & $2.8-4.2 \%$ & blood, liver and spleen & nPCR (SSU), PCR (kDNA), PCR (Cyt B) + sequencing & Brazil & {$[45,66]$} \\
\hline Molossus molossus (insectivorous) & $1-1.6 \%$ & blood, liver and spleen & nPCR (SSU), PCR (kDNA), PCR (Cyt B) + sequencing & Brazil & {$[45,66]$} \\
\hline Molossus rufus (insectivorous) & $1 \%$ & liver, skin, spleen & nPCR (SSU), qPCR (kDNA), PCR (ITS1) + RFLP & Brazil & {$[14,66]$} \\
\hline Myotis nigricans (insectivorous) & $2.9 \%$ & liver, spleen & nPCR (SSU), qPCR (kDNA), PCR (ITS1) + RFLP & Brazil & {$[14,66]$} \\
\hline Nyctinomops laticaudatus (insectivorous) & $10 \%$ & liver, spleen & nPCR (SSU) & Brazil & [66] \\
\hline Phyllostomus hastatus (omnivorous) & $2.9 \%$ & blood & PCR (kDNA), PCR (Cyt b) + sequencing & Brazil & [45] \\
\hline Platyrrhinus lineatus (omnivorous) & $18.2 \%$ & blood, spleen & qPCR (kDNA), PCR (ITS1) + RFLP, PCR (kDNA), PCR (Cyt b) + sequencing & Brazil & {$[14,45]$} \\
\hline Sturnira lilium (nectarivorous) & $25 \%$ & liver, spleen & nPCR (SSU) & Brazil & [66] \\
\hline \multicolumn{6}{|l|}{ Order Didelphimorphia } \\
\hline \multicolumn{6}{|l|}{ Order Primata } \\
\hline Alouatta caraya (black howler monkey) & $2.8 \%$ & ear tissue & PCR (ITS) + RFLP + sequencing & Argentina & [64] \\
\hline Ateles paniscus (spider monkey) & $100 \%$ & blood & PCR (kDNA), PCR (ITS) + RFLP & Brazil & [67] \\
\hline \multicolumn{6}{|l|}{ Order Rodentia } \\
\hline Akodon spp. & $7.1 \%$ & blood & PCR (kDNA) + hybridisation & Bolivia & [41] \\
\hline Necromys (sin. Bolomys) lasiurus & $20 \%$ & ear skin & PCR-D7 24S $\alpha$ rRNA (trypanosomatids) and PCR (ITS) + sequencing & Brazil & [35] \\
\hline Oligoryzomys spp. (rice rat) & $25 \%$ & blood & PCR (kDNA) + hybridisation & Bolivia & [41] \\
\hline Hylaeamys (Oryzomys) acritus & $33.3 \%$ & tail skin & PCR (kDNA) + sequencing & Bolivia & [68] \\
\hline Oryzomys nitidus & $13.3 \%$ & tail skin & PCR $(\mathrm{kDNA})+$ sequencing & Bolivia & [68] \\
\hline
\end{tabular}

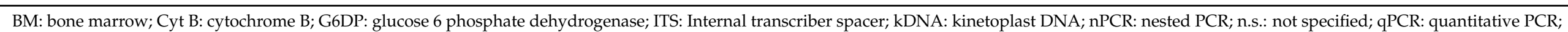

RFLP: restriction fragment length polymorphism; SSU: small subunit of ribosomal RNA. 


\subsection{Wild Animals Infected with Leishmania mexicana}

In this review, data regarding infection with L. mexicana in wild animals were mainly from the USA and Mexico, two countries where the parasite is frequently reported, but data from rodents and carnivores from Brazil and Bolivia were also included (Supplementary Materials File S3). The species was present in other American territories such as Venezuela, Colombia, Ecuador and all countries in Central America [3,5].

According to the data from the systematic review, thirty-one species of wild animals from six orders were found to be infected with L. mexicana. In carnivores, only one out of two Molina's hog-nosed skunks (Conepatus chinga rex) were infected with L. mexicana in Bolivia, and the parasite was isolated by inoculation in hamster and subsequently analysed by isoenzyme analysis and hybridisation [41]. Samples from seven grey foxes (Urocyon cinereoargenteus) were analysed by ELISA, showing 100\% prevalence in Mexico [69] (Supplementary Materials File S3). Both species should be considered as sentinel or even reservoirs, due to the parasite's isolation and high values of positivity.

Thirteen species of bats (order Chiroptera) were also found infected with the parasite in Mexico, employing skin, heart, liver and spleen in a PCR of kDNA and SSU [5]. The authors found infection rates ranging from $4-100 \%$ of the animals [70].

In rodents, eleven species were infected in ten different surveys, with Handleyomis (sin. Oryzomis) melanotis, Ototylomis phyllotis, Peromyscus yucatanicus and Sigmodon hispidus being the species with the higher levels of infection (100\% in at least one study), which may indicate their role as reservoirs of the disease $[33,58,71-78]$. Within the order Didelphimorphia, the Mexican mouse opossum (Marmosa mexicana) [71] and the northern anteater [79] were found to be infected in Mexico employing PCR.

The order Primates was less explored, and only indirect evidence of the infection was reported by serology (ELISA, IFAT and Western blot). A prevalence of 5-37.5\% was found in two species of howler monkeys (Alouatta palliate and A. pigra) in Mexico [80].

The base of the tail was the election site for detection or isolation of L. mexicana in rodents and marsupials, with $100 \%$ of infection in many studies in which animals with lesions were sampled [71-73,77], but the ear and foot were also included [76] (Supplementary Materials File S3). When other organs were investigated, such as liver, spleen, kidney or heart, they were also infected, but at lower percentages (11-66.7\%) [72]. Heart, liver, spleen and skin were also employed to find infections in Chiroptera [70], while lymph nodes, lung, spleen, liver and kidney tissues were used in the northern anteater, with DNA detection by PCR only in spleen [79].

In general, wild animals showed mild clinical signs of leishmaniasis and no external signs were reported in the orders Carnivora, Chiroptera, Pilosa and Primates. On the contrary, rodents and marsupials were reported with cutaneous clinical signs in most of the surveys, including swollen skin, depigmentation, ulcers, alopecia and erythema, mainly at the base of the tail. This fact can be explained because the authors were searching for lesions to find reservoirs of the disease [71,72,77].

Wild animals infected with L. mexicana, along with techniques and organs or tissues positive to the parasite are shown in Table 4. 
Table 4. Wild animals infected with L. mexicana. Organs or tissues where the parasite was detected, as well as the techniques employed, are indicated.

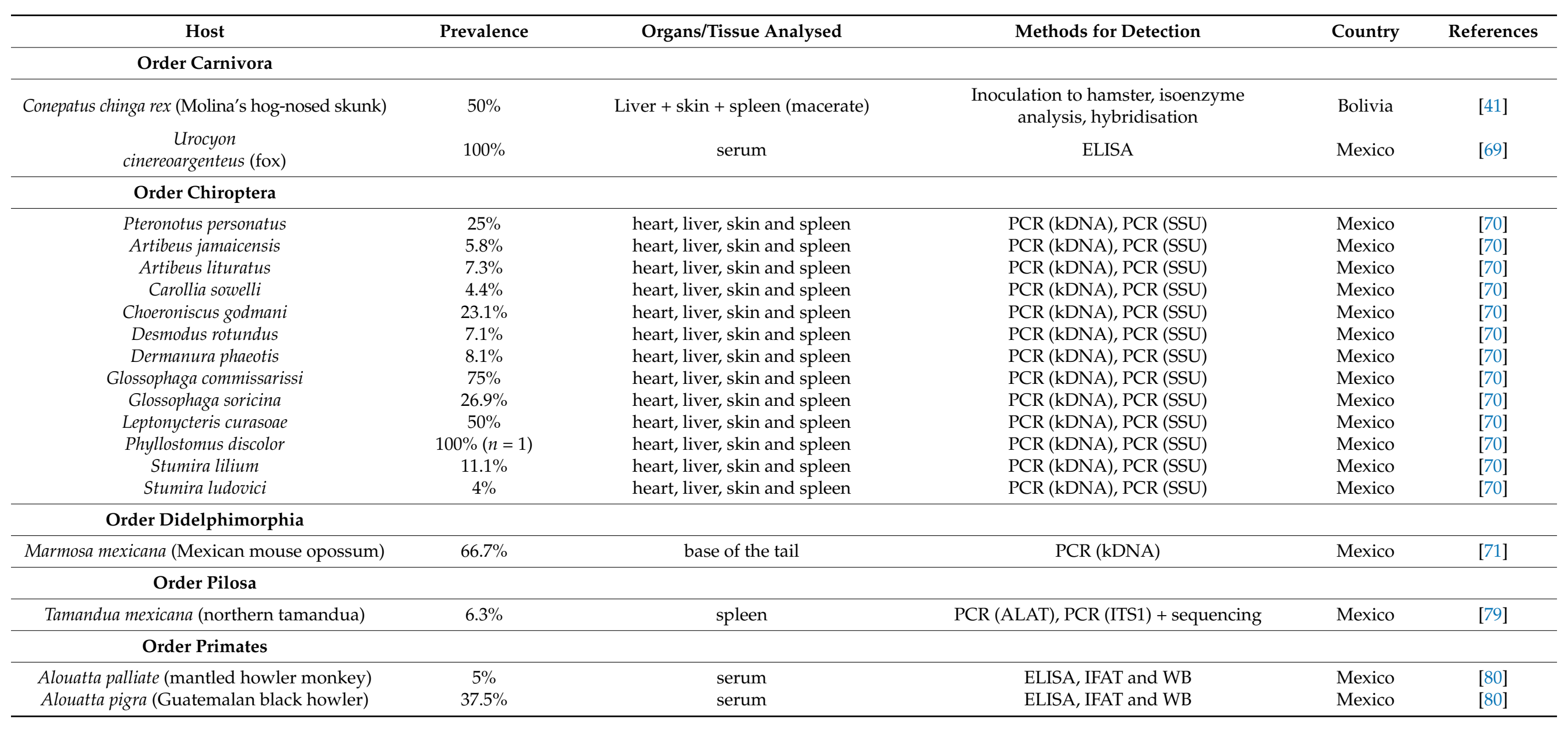


Table 4. Cont.

\begin{tabular}{|c|c|c|c|c|c|}
\hline Host & Prevalence & Organs/Tissue Analysed & Methods for Detection & Country & References \\
\hline \multicolumn{6}{|l|}{ Order Rodentia } \\
\hline Heteromys gaumeri & $46.3 \%$ & base of the tail & PCR (kDNA) & Mexico & [71] \\
\hline Heteromys desmarestianus & $100 \%$ & base of the tail & PCR (kDNA) & Mexico & [71] \\
\hline Neotoma micropus (woodrats) & $7.3-50 \%$ & skin, ear tissue & $\begin{array}{l}\text { Culture, PCR (kDNA), Culture of lesions + } \\
\text { PCR + isoenzyme analysis of cultures }\end{array}$ & USA & {$[73,74]$} \\
\hline Neotoma floridana (eastern woodrat) & $100 \%$ & ear, foot & Smears, PCR & USA & [76] \\
\hline Handleyomys (Oryzomys) melanotis & $65-100 \%$ & skin (base-tail, lesions), liver and spleen & Culture, Mab, imprints and PCR (kDNA) & Mexico & {$[71,72,75,77]$} \\
\hline Ototylomis phyllotis & $75.5-100 \%$ & skin (base-tail), liver & Culture, Mab, imprints and PCR (kDNA) & Mexico & {$[71,72,75]$} \\
\hline Peromyscus yucatanicus & $28.6-100 \%$ & $\begin{array}{c}\text { skin (base-tail), heart and kidney, liver, } \\
\text { spleen }\end{array}$ & Culture, PCR (kDNA) and imprints & Mexico & {$[71,72]$} \\
\hline Rattus rattus (black rat) & $2.9-19 \%$ & blood & Culture, PCR (kDNA) + RFLP/hybridisation & $\begin{array}{l}\text { Venezuela, } \\
\text { Brazil }\end{array}$ & {$[33,58]$} \\
\hline Reithrodontomys gracilis & $66.6 \%$ & skin (base-tail) & Culture, PCR (kDNA) & Mexico & [71] \\
\hline $\begin{array}{l}\text { Sigmodon hispidus } \\
\text { (cotton rat) }\end{array}$ & $58.8-100 \%$ & liver, skin (base-tail, lesion) and spleen & Imprints, culture, Mab and PCR (kDNA) & Mexico & {$[71,72,75,77]$} \\
\hline Trichomys apereoides & $27.8 \%$ & blood & PCR (kDNA) + hybridisation & Brazil & [58] \\
\hline
\end{tabular}

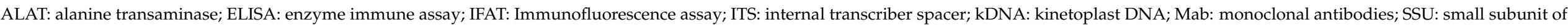
ribosomal RNA. 
In previous reviews, several species from publications prior to 1990 were reported to be infected with L. mexicana (Agouti paca, Marmosa robinson, Nyctomys sumichrasti, Oryzomis capito, Proechymis spp., Reithrodontomys gracilis) [23,24].

\subsection{Wild Animals Infected with Leishmania infantum (L. chagasi)}

L. infantum is the most globally distributed of all species of zoonotic Leishmania. Australia is considered free of L. infantum, but the protozoan is present on almost all continents with available data, including Southern Europe, Africa, Asia and the Americas from north (excluding Alaska and Canada) to south. African countries and Brazil report more than $90 \%$ of the human VL cases around the world, but detailed characterised focusses are more frequently reported in Brazil and Mediterranean countries (North Africa and South Europe) [3,5].

Techniques employed to detect infection with L. infantum in different parts of the world are similar to those previously described for L. braziliensis. Serology was mainly employed in carnivores, primates and occasionally in marsupials or other species, such as rodents or Lagomorpha (Supplementary Materials Files S4 and S5), while the rest of the species were examined preferentially by PCR. Among the serological techniques, ELISA, IFAT, DAT or rapid test (rK39) were extensively employed. The most frequent target, again, was kDNA, but other targets, such as SSU and ITS1 and the repeat region, were also used in several studies and animal species. Less frequently used targets include cytochrome B (Cyt B), HSP70, ITS2, glyceraldehyde phosphate hydrogenase (GAPDH) and $\alpha$-tubulin (for details, see Supplementary Materials File S4). Xenodiagnosis or culture were employed only in a few occasions.

Blood, skin, liver and spleen were the most employed tissues for PCR detection, but heart, lungs, lymph nodes, intestines, kidney and bone marrow were also used in several studies. Blood was more frequently employed in carnivores, marsupials and primates, because it is easier to obtain, while other tissues were accessible only during post-mortem examinations or after fatal clinical cases or euthanasia of the animals. This was the case for rodents, some bats, several clinical cases of carnivores, and road-killed mammals. Hair and eye swabs were also successfully tested in some studies (Supplementary Materials Files S4 and S5).

\subsubsection{L. infantum in the Americas}

According to the literature, eight orders of wild animals are infected with L. infantum in the Americas: Carnivores, Chiroptera, Cingulata, Didelphimorphia, Lagomorpha, Pilosa, Primates and Rodentia (Supplementary Materials File S4). Carnivores were the most widely studied, mainly because domestic and wild carnivores are considered reservoirs of the disease, but also because clinical cases are more frequently reported in them, both in nature and in zoological parks [24,25]. The crab-eating fox (Cerdocyon thous) is a widespread carnivore in South America that can act as a reservoir of leishmaniasis for humans, since it can be found in forest locations as well as in residential areas. It was found to be infected with L. infantum or exposed to the parasite (positive serology) in several publications, some of which were clinical cases, and thus were not considered in this study. The percentage of infection varied widely among the studies when including more than one animal (4-75\%), and exposure to the parasite was demonstrated by serology (i.e., ELISA, IFAT), while culture, microscopy of smears, PCR followed by sequencing and inoculation of hamsters were employed to detect the parasite [81-89]. Several organs and tissues tested positive via PCR: bone marrow, heart, lymph nodes, liver, lungs, skin and spleen. Mainly serological test were employed in the maned wolf (Chrysocyon brachyurus) with prevalence values from $10 \%$ to $75 \%$ depending on the study [82,84,85,88-90], while the parasite was found only in bone marrow and skin by PCR [84,85]. In the bush dog (Speothos venaticus), several techniques were employed including serology, culture of isolates, PCR, smears and histopathology. While most studies reported results from only one or two animals, only three studies analysed a higher number (4-6) and found 33.3\% positives using PCR (blood) 
and $60-100 \%$ of the animals positive by serology [84,85,89-91] (Supplementary Materials File S4). The potential transmission to the vector was demonstrated in manned wolves and bush dogs [89], which reinforces their role as reservoirs.

Several studies investigated free-ranging carnivores by serology using a direct agglutination test (DAT), and positive values were found in tayras (Eira barbara), lesser grison (Galictis cuja) and coatis (Nasua nasua) in Brazil at high serum dilutions ( $\geq 1: 1280$ ) [92]. In carnivores kept in captivity, serology was also employed to demonstrate the presence of antibodies against the parasites in ocelots (Leopardus pardalis), hoary foxes (Lycalopex-Pseudalopex vetulus), jaguars (Panthera onca), Siberian tigers (Panthera tigris altaica), African lions (Panthera leo) and cougars (Puma concolor) (Supplementary Materials File S4) [84,90,93,94]. Clinical signs of VL were more frequent in wild canids compared to wild felines and included weight loss, anaemia, lymph node enlargement, vomiting, diarrhoea and polydipsia/polyuria, which were described in some of the animals from the previously mentioned species, such crab-eating foxes [85], bush dogs [84,85], hoary foxes [84], Siberian tigers and maned wolves $[84,90]$. African lions were reported to test positive for the first time by PCR (kDNA) followed by RFLP, but the animal did not show clinical signs [94]. Finally, Leishmania infection (probably L. infantum) was found in the kidney of one road-killed crab-eating raccoon (Procyon cancrivorus) in Brazil by PCR followed by sequencing [86].

The DNA of L. infantum was found in at least 17 species of bats in nine studies, including one hematophagous species and several frugivorous, omnivorous or insectivorous ones [14,32,44,45,66,95-98]. The feeding habits of the animals were relevant, since the oral route was suggested for transmission in animals feeding on insects, including the vector of leishmaniasis [14]. They also shared the same ecological niche in bat caves and probably other locations. Values of infection varied widely, from less than $1 \%$ to $100 \%$ of the analysed bats, being infected mainly in the blood but also in the liver, skin, spleen and even in oral swab samples [32]. PCR followed by RFLP or sequencing was employed in the studies and, when sensitive primers were employed, a prevalence higher than $30 \%$ was usually obtained [95].

A small number of species of the orders Cingulata and Pilosa were found to be infected with L. infantum in Brazil. The lesser anteater (Tamandua tetradactyla) was reported to test positive by PCR (kDNA) in blood and bone marrow in 2013 [99] and again in 2014, together with giant anteaters (Myrmecophaga tridactyla) and one seven-banded armadillo (Dasypus septemcinctus) found dead on the roads in Brazil, employing PCR from several tissues [86].

Marsupials were studied in several surveys by PCR or serology (Supplementary Materials File S4). The white-eared opossum (Didelphis albiventris) was analysed by six groups in Brazil, who found the parasite in blood, bone marrow, lungs, kidney, skin and spleen by culture or PCR (kDNA, ITS1 or SSU) and sequencing or RFLP [38,39,50,54,86,100,101], with percentages of infection between $6.3 \%$ and $22.2 \%$. The big-eared opossum (Didelphis aurita) was positive at a low percentage in Brazil by PCR, spleen imprints and serology (rK39), and one of the animals displayed spleen enlargement, but no other clinical signs were recorded from the rest [102]. In Brazil as well as in Colombia and Venezuela, the common opossum (Didelphis marsupialis) was widely analysed [102-107]. Two studies in Colombia demonstrated the transmission of isolates from common opossums to hamster, highlighting their role as reservoirs of L. infantum $[105,106]$. The parasite was found in several tissues employing PCR (kDNA, SSU and ITS1) followed by hybridisation or RFLP [38,103,107]. Two studies in Brazil employed serology and PCR simultaneously. In the first one, the authors found $9-21.6 \%$ of the animals positive using serology, and only $5 \%$ positive by PCR-RFLP [38], while the other study analysed 112 individuals of two species (i.e., whiteeared and big-eared opossums), and found high percentages of positivity (71-91.6\%) with both techniques (see Supplementary Materials File S4 for details).

Lagomorphs were scarcely reported as exposed to L. infantum in the Americas, with one European hare (Lepus europaeus) found positive in Brazil by DAT and with a low antibody titre (1:320) [92]. 
Infection with L. infantum in primates were studied in five surveys, and eleven species were reported with DNA of the parasite. Several species of captive primates showed high prevalence values when employing PCR (kDNA) in an endemic area of Brazil including brown howler monkeys (Alouatta guariba), black-headed night monkeys (Aotus nigriceps), black-fronted titi (Callicebus nigrifons), golden-bellied capuchin (Cebus xanthosternos), golden-headed lion tamarin (Leontopithecus chrysomelas), bald-faced saki (Pithecia irrorata) and emperor tamarin (Saguinus imperator). Among them, one black-fronted titi was found dead with clinical signs compatible with leishmaniasis, but the rest did not show clinical signs [108]. On the other hand, free-ranging howler monkeys (Alouatta caraya) sampled at the marginal area of an endemic region from Argentina displayed low values of prevalence (6.3\%) [64]. Two other studies found indirect evidence of infection with the parasite using DAT in one white-tufted-ear marmoset (Callithrix jacchus) [109] and 26.9\% of the black-tufted marmosets (Callithrix penicillata) [109]; the last study also employed PCR of the skin. Positive serology was detected in twenty-two percent of red howler monkeys (Alouatta seniculus) in French Guiana, and data were further confirmed by PCR (110).

Rodents occupied most of the attention of researchers investigating L. infantum in the Americas, and twelve studies fulfilled the inclusion criteria of this systematic review $[21,36,39,50,53,58,86,92,101,106,107,110]$. Most of the studies employed different PCR approaches in several tissues, although in one study the authors detected antibodies. Brazilian guinea pigs were reported to be infected in Brazil by PCR in heart tissue [86]. The infection was also found in two species of porcupines from Brazil: the prehensile tailed porcupine (Coendu-Sphiggurus villosus) by serology (DAT) [92], which is indirect evidence of the parasitism, and the Paraguayan hairy dwarf porcupine (Coendou-Sphiggurus spinosus) by PCR and sequencing from several tissues Supplementary Materials File S4) [86]. Agouties were also reported to test positive for L. infantum in the spleen (16.7\%), skin and blood by PCR $[36,110]$. The giant rodent capybara (Hydrochoerus hydrochaeris) was positive in the lungs by PCR and sequencing [86]. Several species from wild mice, rats and cricetidae of the genera Cerradomys, Clyomis, Holochilus, Hylaeamys, Nectomys, Oryzomys, Proechymis, Rhipidomys and Trichomys were reported to be infected with L. infantum in several surveys, and in previous studies the potential role as reservoir of some of them was indicated [24]. The authors employed distinct approaches of PCR followed by RFLP, hybridisation or sequencing $[21,36,39,50,58,106,110]$.

Synanthropic rodents, such as the house mouse (Mus musculus), the black rat (Rattus rattus) and the brown rat (Rattus norvegiccus) were investigated in Brazil and Venezuela. Researchers found $20 \%$ of house mice to be infected [50], while the prevalence in black rats varied widely, with values from $0.1 \%$ to $100 \%$ using several approaches of PCR followed by hybridisation, RFLP or sequencing $[21,39,50,53,58,107]$. Almost $17 \%$ of brown rats were positive by nPCR and sequencing [50]. These synanthropic species of rodents could act as relevant reservoirs of leishmaniasis, since they were infected at high percentages and share habitats with humans.

Additional species were analysed in other surveys or in some of the previous studies in which the authors could not characterise the parasite at the species level (Supplementary Materials File S4) [44,91,111-118]. Indirect evidence of Leishmania spp. was found in the USA using rapid tests (rk30 antigen) in several wild carnivores such as coyotes (Canis latrans, 1.6\%), American red foxes (Vulpes fulvus, 9.1\%) and grey foxes (Urocyon cinereoargenteus, $2 \%)[111,112]$. On the other hand, DNA of Leishmania spp. was detected in several species, including carnivores, such as South American grey foxes (Lycalopex-Pseudalopex griseus) [113] and Neotropical otters (Lontra longicaudis), and some species of primates, such as black-headed night monkeys (Aotus nigriceps), black-bearded sakis (Chiropotes satanas) and grey-woolly monkeys (Lagothrix cana) in Brazil [114]. Among rodents, Leishmania spp. DNA was reported in the blood of a red-tailed squirrel (Sciurus granatensis) in Venezuela [103]. All this information is summarized in Table 5. 


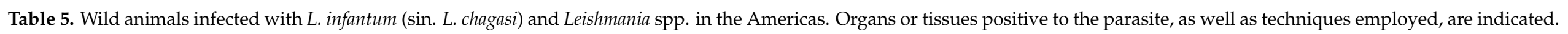

\begin{tabular}{|c|c|c|c|c|c|}
\hline Host & Prevalence & Organs/Tissue Analysed & Method of Detection & Country & Reference \\
\hline \multicolumn{6}{|l|}{ Order Carnivora } \\
\hline Cerdocyon thous (crab-eating fox) & $4-100 \%$ & $\begin{array}{l}\text { BM, heart, liver, lung, } \\
\text { mesenteric LN, serum skin } \\
\text { and spleen }\end{array}$ & $\begin{array}{l}\text { Smears, ELISA, culture, PCR, inoculation to hamster, } \\
\text { IFAT, xenodiagnosis vector, PCR (kDNA) + sequencing, } \\
\text { PCR (kDNA) + sequencing * }\end{array}$ & Brazil & {$[81-87,89]$} \\
\hline Chrysocyon brachyurus (maned wolf) & $10-75 \%$ & $\mathrm{BM}$, serum and skin & $\begin{array}{l}\text { ELISA, IFAT, PCR (kDNA), PCR (kDNA) + sequencing, } \\
\text { IC rk39, xenodiagnoses in vector }\end{array}$ & Brazil & $\begin{array}{l}{[82,84,85,} \\
88-90]\end{array}$ \\
\hline Eira barbara (tayra) & n.s. & serum & $\operatorname{DAT}(n=3)$ & Brazil & [92] \\
\hline Galictis cuja (lesser grison) & n.s. & serum & $\operatorname{DAT}(n=3)$ & Brazil & [92] \\
\hline Leopardus pardalis (ocelot) & $75 \%$ & serum & ELISA, & Brazil & [90] \\
\hline Lycalopex (Pseudalopex) vetulus (hoary fox) & $33.3 \%$ & $\mathrm{BM}$, serum & IFAT, ELISA, PCR (kDNA) & Brazil & [84] \\
\hline Nasua nasua (coati) & n.s. & serum & $\operatorname{DAT}(n=2)$ & Brazil & [92] \\
\hline Speothos venaticus (bush dogs) & $33.3-100 \%$ & $\begin{array}{l}\text { blood, LN, serum, skin, } \\
\text { spleen and other tissues } \\
\text { (liver, kidney, lung and } \\
\text { large intestine) }\end{array}$ & $\begin{array}{l}\text { PCR (kDNA), PCR (kDNA) + sequencing, histopathology, } \\
\text { IHC, ELISA, IFAT, IC rk39, xenodiagnoses in vector }\end{array}$ & Brazil & $\begin{array}{l}{[84,85,89-} \\
91]\end{array}$ \\
\hline Panthera onca (jaguar) & $20-50 \%$ & blood, $\mathrm{LN}$ and serum & PCR (kDNA) + RFLP, ELISA, IC & Brazil & {$[90,93]$} \\
\hline Panthera tigris altaica (Siberian tiger) & $50 \%$ & serum & ELISA, IC & Brazil & {$[90]$} \\
\hline Procyon cancrivorus (crab-eating racoon) & $33.3 \%$ & kidney & PCR (kDNA) + sequencing * & Brazil & [86] \\
\hline \multicolumn{6}{|l|}{ Order Chiroptera } \\
\hline Artibeus planirostris (frugivorous) & $7.4-16.7 \%$ & blood & PCR (kDNA), PCR (Cyt B) + sequencing & Brazil & {$[45,95]$} \\
\hline Artibeus lituratus (frugivorous) & $40.9 \%$ & blood & qPCR (kDNA) & Brazil & [95] \\
\hline Desmodus rotundus (hematophagous) & $50 \%$ & liver, skin & $\begin{array}{l}\text { qPCR (kDNA), PCR (ITS1) + RFLP, PCR (kDNA), nPCR } \\
\text { (SSU) + sequencing }\end{array}$ & Brazil & {$[14,44]$} \\
\hline Carollia perspicillata (frugivorous) & $3-27.3 \%$ & blood, spleen & $\begin{array}{l}\text { Culture, qPCR (kDNA), qPCR (SSU), PCR (kDNA), PCR } \\
\text { (ITS2) + sequencing }\end{array}$ & $\begin{array}{l}\text { Venezuela, Brazil } \\
\text { and French Guiana }\end{array}$ & [95-97] \\
\hline Eumops perotis (insectivorous) & $11.1 \%$ & blood & PCR $(k D N A)$, PCR (Cyt B) + sequencing & Brazil & [45] \\
\hline Eptesicus furinalis (frugivorous) & $100 \%(n=1)$ & blood & PCR (kDNA), PCR (Cyt B) + sequencing & Brazil & {$[45]$} \\
\hline Glossophaga soricina (nectarivorous) & $0.7-100 \%$ & blood, liver and spleen & $\begin{array}{c}\text { nPCR (SSU), PCR (kDNA), PCR (Cyt B) + sequencing, } \\
\text { qPCR (kDNA), PCR (kDNA) and nPCR } \\
\text { (SSU) + sequencing }\end{array}$ & Brazil & $\begin{array}{l}{[44,45,66,} \\
95]\end{array}$ \\
\hline Myotis nigricans (insectivorous) & $33.3 \%$ & liver & PCR (kDNA) + nPCR (SSU) + sequencing & Brazil & [44] \\
\hline
\end{tabular}


Table 5. Cont.

\begin{tabular}{|c|c|c|c|c|c|}
\hline Host & Prevalence & Organs/Tissue Analysed & Method of Detection & Country & Reference \\
\hline Molossus molossus (insectivorous) & $0.5 \%-100 \%$ & blood, liver and spleen & $\begin{array}{c}\text { nPCR (SSU), qPCR (kDNA), PCR (ITS1) + RFLP, PCR } \\
\text { (kDNA), PCR (Cyt B) + sequencing, PCR (kDNA) + nPCR } \\
\text { (SSU) + sequencing }\end{array}$ & Brazil & $\begin{array}{c}{[14,44,45,} \\
66]\end{array}$ \\
\hline Molossus pretiosus (insectivorous) & $21.1 \%$ & liver, skin & PCR (kDNA) + nPCR (SSU) + sequencing & Brazil & [44] \\
\hline Molossus rufus (insectivorous) & $20-100 \%$ & liver, spleen & $\begin{array}{c}\text { qPCR (kDNA), PCR (ITS1) + RFLP, } \\
\text { nPCR (SSU) + sequencing }\end{array}$ & Brazil & {$[14,44]$} \\
\hline Molossidae spp. (insectivorous) & $40 \%$ & liver, skin & PCR (kDNA)+ nPCR (SSU) + sequencing & Brazil & [44] \\
\hline Nyctinomops laticaudatus (insectivorous) & $40 \%$ & liver, skin & PCR (kDNA) and nPCR (SSU) + sequencing & Brazil & [44] \\
\hline Platyrrhynus lineatus (frugivorous) & $15.4 \%$ & blood & gPCR (kDNA) & Brazil & [95] \\
\hline Phyllostomus hastatus (omnivorous) & $5.9 \%$ & blood & PCR (kDNA), PCR (Cyt B) + sequencing & Brazil & {$[45]$} \\
\hline Phyllostomus discolor (omnivorous) & $100 \%(n=1)$ & blood & gPCR (kDNA) & Brazil & {$[95]$} \\
\hline Pteronotus parnellii (insectivorous) & $100 \%(n=1)$ & blood & PCR (SSU), PCR (GAPDP) & Brazil & [98] \\
\hline Bats (n.s.) & $0.1 \%$ & oral swab & PCR (SSU) + sequencing * & Brazil & [32] \\
\hline \multicolumn{6}{|l|}{ Order Cingulata } \\
\hline $\begin{array}{c}\text { Dasypus septemcinctus (seven-banded } \\
\text { armadillo) }\end{array}$ & $100 \%(n=1)$ & liver & PCR $(\mathrm{kDNA})+$ sequencing * & Brazil & [86] \\
\hline Didelphis albiventris (white-eared opossum) & $6.3-22.2 \%$ & $\begin{array}{l}\text { blood, BM, liver, lung, } \\
\text { kidney, skin and spleen }\end{array}$ & $\begin{array}{c}\text { Culture, PCR (ITS1) + RFLP, PCR (kDNA), PCR (kDNA) + } \\
\text { sequencing, nPCR (SSU) + sequencing, PCR (kDNA), } \\
\text { PCR (ITS1) }\end{array}$ & Brazil & $\begin{array}{l}{[39,50,54} \\
86,100]\end{array}$ \\
\hline Didelphis aurita (big-eared opossum) & $6.3 \%$ & LN, serum and spleen & Spleen smears, PCR (kDNA) + hybridisation IC rk39 & Brazil & [102] \\
\hline $\begin{array}{l}\text { Didelphis marsupialis } \\
\text { (common opossum) }\end{array}$ & $7.1-40.5 \%$ & $\begin{array}{l}\text { blood, BM, liver, serum, } \\
\text { skin and spleen }\end{array}$ & $\begin{array}{l}\text { smears, Culture, inoculation to hamster + isoenzyme, } \\
\text { Mab, PCR (kDNA) + hybridisation, IFAT, DAT, } \\
\text { PCR+RFLP, nPCR (SSU), PCR (ITS1) }\end{array}$ & $\begin{array}{l}\text { Brazil, Colombia } \\
\text { and Venezuela }\end{array}$ & $\begin{array}{c}{[38,103-} \\
107]\end{array}$ \\
\hline $\begin{array}{l}\text { Didelphis sp. } \\
\text { D. albiventris } \\
\text { D. aurita }\end{array}$ & $91.6 \%$ & blood, BM & PCR (kDNA) ELISA, FML-ELISA, smears, culture & Brazil & [101] \\
\hline \multicolumn{6}{|l|}{ Order Lagomorpha } \\
\hline Lepus europaeus (European hare) & n.s. & serum & $\operatorname{DAT}(n=1)$ & Brazil & [92] \\
\hline
\end{tabular}


Table 5. Cont.

\begin{tabular}{|c|c|c|c|c|c|}
\hline Host & Prevalence & Organs/Tissue Analysed & Method of Detection & Country & Reference \\
\hline \multicolumn{6}{|l|}{ Order Pilosa } \\
\hline Myrmecophaga tridactyla (giant anteater) & $33.3 \%$ & $\begin{array}{l}\text { heart, kidney, lung and } \\
\text { mesenteric LN }\end{array}$ & PCR (kDNA) + sequencing * & Brazil & [86] \\
\hline Tamandua tetradactyla (lesser anteater) & $50-100 \%$ & $\begin{array}{l}\text { BM, liver, lung and } \\
\text { mesenteric LN }\end{array}$ & PCR (kDNA), PCR (ITS1) + sequencing & Brazil & {$[86,99]$} \\
\hline \multicolumn{6}{|l|}{ Order Primates } \\
\hline Alouatta caraya (black howler) & $3.7 \%$ & ear tissue & PCR (ITS) + RFLP + sequencing & Brazil, Argentina & [64] \\
\hline Alouatta guariba (brown howler monkey) & 12.5 & blood & PCR (kDNA) & Brazil & [108] \\
\hline Alouatta seniculus (red howler monkey) & $22.2 \%$ & blood & PCR (kDNA), PCR (ITS2), PCR (SSU), IC & French Guiana & [119] \\
\hline $\begin{array}{c}\text { Aotus nigriceps (black-headed } \\
\text { night monkey) }\end{array}$ & $100 \%(n=1)$ & blood & qPCR (kDNA) & Brazil & {$[108]$} \\
\hline Callicebus nigrifons (black-fronted titi) & $33.3 \%$ & $\begin{array}{l}\text { blood, liver, lung, intestine } \\
\text { and spleen }\end{array}$ & qPCR (kDNA), IHC, & Brazil & [108] \\
\hline $\begin{array}{c}\text { Callithrix jacchus } \\
\text { (white-tufted-ear marmoset) }\end{array}$ & $100 \%(n=1)$ & serum & DAT & Brazil & {$[92]$} \\
\hline Callithrix penicillata, C. jacchus & $26.9 \%$ & blood, skin & DAT, PCR + sequencing & Brazil & [109] \\
\hline $\begin{array}{l}\text { Leontopithecus chrysomelas (golden-headed } \\
\text { lion tamarin) }\end{array}$ & $20 \%$ & blood & qPCR (kDNA) & Brazil & [108] \\
\hline Pithecia irrorata (bald-faced saki) & $50 \%$ & blood & qPCR (kDNA) & Brazil & [108] \\
\hline Saguinus imperator (emperor tamarin) & $100 \%$ & blood & qPCR (kDNA) & Brazil & [108] \\
\hline \multicolumn{6}{|l|}{ Order Rodentia } \\
\hline Cavia aperea (Brazilian guinea pig) & $25 \%$ & heart & PCR $(\mathrm{kDNA})+$ sequencing & Brazil & [86] \\
\hline Cerradomys (Oryzomys) subflavus & $25 \%$ & $\mathrm{BM}$, liver and spleen & nPCR (SSU) + sequencing & Brazil & {$[50]$} \\
\hline $\begin{array}{c}\text { Coendu (Sphiggurus) villosus (prehensile } \\
\text { tailed porcupine) }\end{array}$ & n.s. & serum & $\operatorname{DAT}(n=2)$ & Brazil & {$[92]$} \\
\hline $\begin{array}{c}\text { Coendou (Sphiggurus) spinosus (Paraguayan } \\
\text { hairy dwarf porcupine) }\end{array}$ & $20 \%$ & $\begin{array}{l}\text { heart, kidney, liver and } \\
\text { spleen }\end{array}$ & PCR (kDNA) + sequencing & Brazil & [86] \\
\hline Clyomis laticeps & $5.2 \%$ & spleen & PCR (kDNA) + PCR (HSP70) & Brazil & [36] \\
\hline Dasyprocta azarae & $16.7 \%$ & spleen & PCR (kDNA) + PCR (HSP70) & Brazil & [36] \\
\hline Dasyprocta sp. & n.s. & blood, skin & PCR (kDNA) + PCR (ITS), PCR (HSP70) + sequencing & Brazil & [110] \\
\hline Holochilus scieurus & $10 \%$ & skin, spleen & PCR (kDNA) & Brazil & [39] \\
\hline Hydrochoerus hydrochaeris (capybara) & $50 \%$ & lung & PCR (kDNA) + sequencing & Brazil & [86] \\
\hline
\end{tabular}


Table 5. Cont

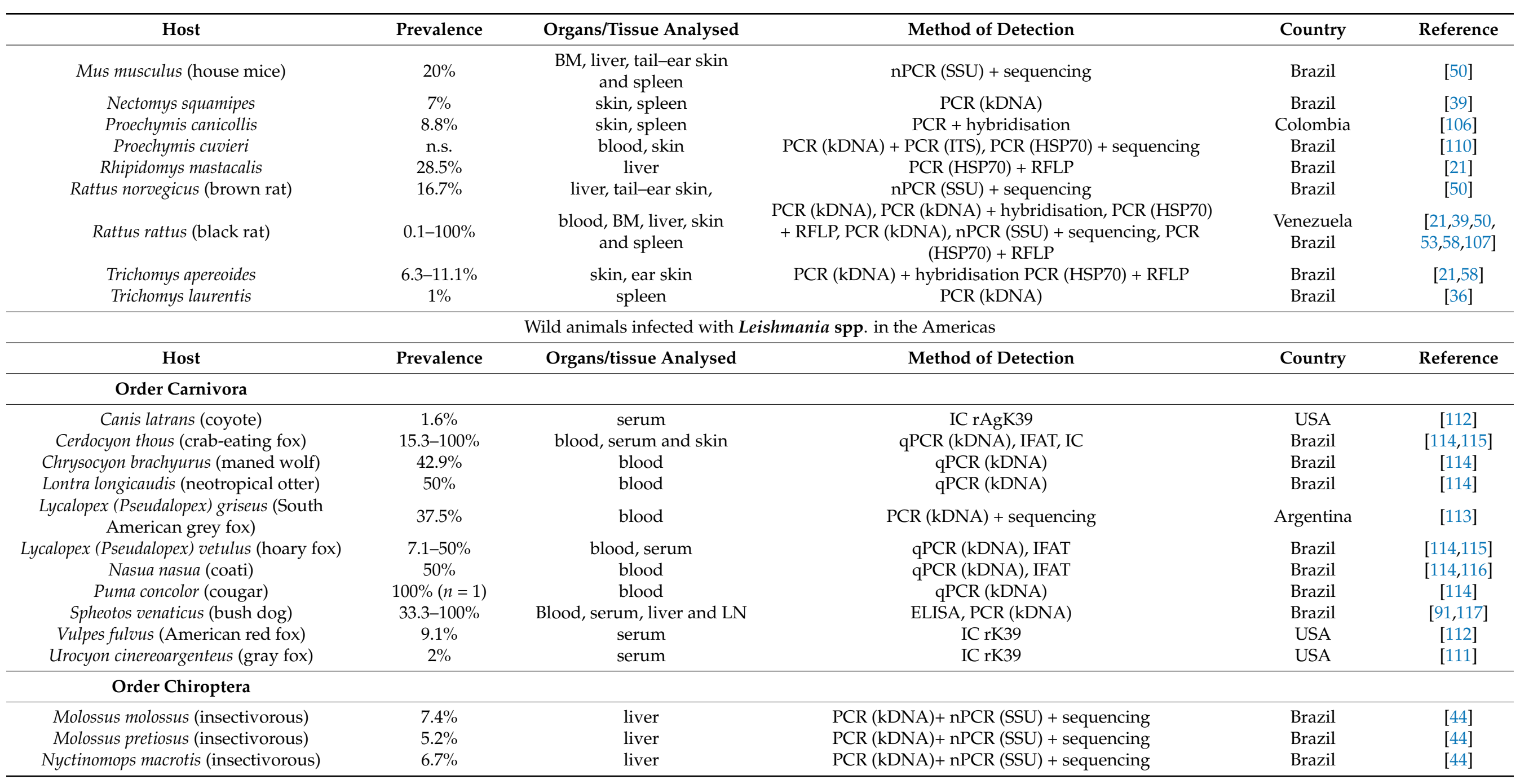


Table 5. Cont.

\begin{tabular}{|c|c|c|c|c|c|}
\hline Host & Prevalence & Organs/Tissue Analysed & Method of Detection & Country & Reference \\
\hline \multicolumn{6}{|l|}{ Order Pilosa } \\
\hline Myrmecophaga tridactyla (giant anteater) & $36.4 \%$ & blood & qPCR (kDNA) & Brazil & [114] \\
\hline Tamandua tetradactyla (lesser anteater) & $33.3 \%$ & blood & qPCR (kDNA) & Brazil & [114] \\
\hline \multicolumn{6}{|l|}{ Order Primates } \\
\hline Alouatta guariba (brown howler monkey) & $37.5 \%$ & blood & PCR (kDNA) & Brazil & [91] \\
\hline $\begin{array}{c}\text { Aotus nigriceps (black-headed } \\
\text { night monkey) }\end{array}$ & $20 \%$ & blood & qPCR (kDNA) & Brazil & [114] \\
\hline Lagothrix cana (gray-woolly monkey) & $33.3 \%$ & blood & qPCR (kDNA) & Brazil & [114] \\
\hline $\begin{array}{c}\text { Leontopithecus chrysomelas (golden-headed } \\
\text { lion tamarin) }\end{array}$ & $16.7 \%$ & blood & qPCR (kDNA) & Brazil & [114] \\
\hline \multicolumn{6}{|l|}{ Order Rodentia } \\
\hline Rattus rattus (black rat) & $9.1 \%$ & serum & IFAT & Dominican Republic & [118] \\
\hline Sciurus granatensis (red-tailed squirrel) & $100 \%(n=1)$ & blood & nPCR (SSU) & Venezuela & [103] \\
\hline
\end{tabular}

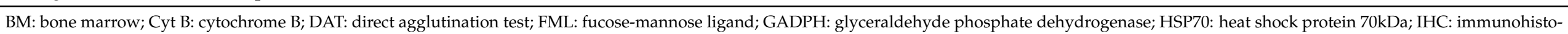

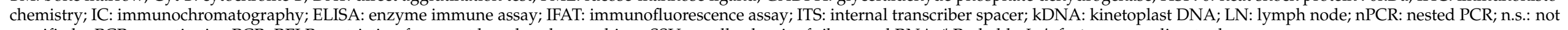
specified; qPCR: quantitative PCR; RFLP: restriction fragment length polymorphism; SSU: small subunit of ribosomal RNA. * Probably L. infantum, according to the sequence. 
The following species have been reported to be infected with L. infantum in the Americas in previous reviews: the rodent Proechymis spinosus, the Brazilian porcupine (Coendu prehensilis) and the fennec fox (Vulpes zerda). More information can be retrieved from the abovementioned reviews [23-25,27].

\subsubsection{L. infantum in Wild Animals from Europe, Asia and Africa}

Carnivores, bats, wallabies, hedgehogs, lagomorphs and rodents tested positive for L. infantum via antibody detection or PCR in several countries in South Europe (Croatia, France, Greece, Italy, Portugal, Spain, Romania), North Africa (Morocco, Tunisia) and Asia (Georgia, Iran, Israel, Saudi Arabia), Spain being the country with the highest number of studies of wild animals (Supplementary Materials File S5).

L. infantum infection was reported in a large list of wild carnivores including 18 species. The golden jackal (Canis aureus) was positive in four studies at low percentages. The lowest values were found in Georgia using a rapid test (2.6\%) [120] and in Romania employing PCR and sequencing of the ITS1 region from bone marrow samples (3\%) [121]. In Iran, $11.6 \%$ of the jackals were found positive by serological test (DAT), and subsequent smears and culture from skin lesions, lymph nodes, spleen and liver were furthered characterised by PCR and sequencing [122]. Only $7.8 \%$ of the animals were found positive by PCR using blood samples [123]. The target or the technique used in each study could influence the results obtained by the different authors.

The wolf was the focus of research of many zoonoses including L. infantum infections. In this review, nine studies reported the animal to be positive for the parasite, although three of them included a low number of animals (three or less). In Croatia, only one wolf was reported positive by PCR and sequencing of the cysteine protease B in lymph nodes [124]. The remaining authors employed PCR of the kDNA region to detect the infection and, in some cases, RFLP and sequencing were later applied. Prevalence values from 33\% to 50\% were found in Spain when using spleen, skin or lymph nodes as samples [125-129] including one study conducted in a non-endemic region [127]. The percentage of infected animals was lower when blood (9\%) [130] or hair (4.1\%) [131] were used to detect the parasite. In Italy, 25\% of the animals were infected when samples from spleen were analysed [132]. Skin lesions were reported only in one study [127].

A smaller number of individuals from wild cats (Felis silvestris) $[127,128,133]$ and genets (Genetta genetta) [125,127-129,133,134] tested positive to L. infantum in samples from skin, liver or spleen employing PCR of the kDNA. The percentage of infection in both species reached $100 \%$ of the sampled animals, although wild cats showed $25 \%$ as the minimum value $[128,133]$, while genets displayed a $10 \%$ prevalence in blood or spleen samples [134]. In two studies, additional PCR and sequencing of the ITS2 region were carried out $[129,133]$.

Several studies were conducted employing similar approaches to detect L. infantum in various species of carnivores. The parasite was found in the spleen or blood of $28.6 \%$ of Egyptian mongoose (Herpestes ichneumon) from Spain [125] and 4.7\% (only spleen) from Portugal [135]. Seventy percent of otters' (Lutra lutra) spleens [136] and 25\% of Iberian lynxes' (Lynx pardinus) samples (spleen and blood) [135] were found to be infected in two studies. Six surveys reported the presence of L. infantum in hair, liver, spleen or lymph nodes of 29-100\% of sampled beech martens (Martes foina) in Spain [127-129,131,133,137]. Values between $30 \%$ and $62 \%$ were found in pine martens (Martes martes) using the same techniques $[127,133,134]$. Badgers (Meles meles) were found infected in the liver or spleen in Italy (53\%) [132] and Spain (26\%) [133]. European minks (Mustela lutreola) were found to be infected with values of 50\% in Spain using a similar methodology [133] but at lower percentages (e.g., 2.1\%) when ELISA or PCR of the ITS1 were employed in Greece [136]. Moreover, $20 \%$ of pole cats (Mustela putorius), $45 \%$ of tigers (Panthera tigris) in a zoo, $20 \%$ of red squirrels (Sciurus vulgaris) and one individual of each species of American mink (Mustela vison) and brown bear (Ursus arctos) were reported to be infected with the protozoa [129,133,137,138]. 
The DNA of L. infantum was found in at least 17 species of bats in nine studies, including one hematophagous species and several frugivorous, omnivorous or insectivorous ones [14,32,44,45,66,95-98]. The feeding habits of the animals were relevant, since the oral route was suggested for transmission in animals feeding on insects, including the vector of leishmaniasis [14]. They also shared the same ecological niche in bat caves and probably other locations. Values of infection varied widely, from less than $1 \%$ to $100 \%$ of the analysed bats, being infected mainly in the blood but also in the liver, skin, spleen and even in oral swab samples [32]. PCR followed by RFLP or sequencing was employed in the studies and, when sensitive primers were employed, a prevalence higher than $30 \%$ was usually obtained [95].

A small number of species of the orders Cingulata and Pilosa were found to be infected with L. infantum in Brazil (Supplementary Materials File S4). The lesser anteater (Tamandua tetradactyla) was reported to test positive by PCR (kDNA) in blood and bone marrow in 2013 [99] and again in 2014, together with giant anteaters (Myrmecophaga tridactyla) and one seven-banded armadillo (Dasypus septemcinctus) found dead on the roads in Brazil, employing PCR from several tissues [86].

Marsupials were studied in several surveys by PCR or serology (Supplementary Materials File S4). The white-eared opossum (Didelphis albiventris) was analysed by six groups in Brazil, who found the parasite in blood, bone marrow, lungs, kidney, skin and spleen by culture or PCR (kDNA, ITS1 or SSU) and sequencing or RFLP [38,39,50,54,86,100,101], with percentages of infection between $6.3 \%$ and $22.2 \%$. The big-eared opossum (Didelphis aurita) was positive at a low percentage in Brazil by PCR, spleen imprints and serology (rK39), and one of the animals displayed spleen enlargement, but no other clinical signs were recorded from the rest [102]. In Brazil as well as in Colombia and Venezuela, the common opossum (Didelphis marsupialis) was widely analysed [102-107]. Two studies in Colombia demonstrated the transmission of isolates from common opossums to hamster, highlighting their role as reservoirs of L. infantum $[105,106]$. The parasite was found in several tissues employing PCR (kDNA, SSU and ITS1) followed by hybridisation or RFLP $[38,103,107]$. Two studies in Brazil employed serology and PCR simultaneously. In the first one, the authors found $9-21.6 \%$ of the animals positive using serology, and only $5 \%$ positive by PCR-RFLP [38], while the other study analysed 112 individuals of two species (i.e., whiteeared and big-eared opossums), and found high percentages of positivity (71-91.6\%) with both techniques (see Supplementary Materials File S4 for details).

Lagomorphs were scarcely reported as exposed to L. infantum in the Americas, with one European hare (Lepus europaeus) found positive in Brazil by DAT and with a low antibody titre (1:320) [92].

Infection with L. infantum in primates were studied in five surveys, and eleven species were reported with DNA of the parasite. Several species of captive primates showed high prevalence values when employing PCR (kDNA) in an endemic area of Brazil including brown howler monkeys (Alouatta guariba), black-headed night monkeys (Aotus nigriceps), black-fronted titi (Callicebus nigrifons), golden-bellied capuchin (Cebus xanthosternos), golden-headed lion tamarin (Leontopithecus chrysomelas), bald-faced saki (Pithecia irrorata) and emperor tamarin (Saguinus imperator). Among them, one black-fronted titi was found dead with clinical signs compatible with leishmaniasis, but the rest did not show clinical signs [108]. On the other hand, free-ranging howler monkeys (Alouatta caraya) sampled at the marginal area of an endemic region from Argentina displayed low values of prevalence (6.3\%) [64]. Two other studies found indirect evidence of infection with the parasite using DAT in one white-tufted-ear marmoset (Callithrix jacchus) [109] and 26.9\% of the black-tufted marmosets (Callithrix penicillata) [109]; the last study also employed PCR of the skin. Positive serology was detected in twenty-two percent of red howler monkeys (Alouatta seniculus) in French Guiana, and data were further confirmed by PCR (110).

Rodents occupied most of the attention of researchers investigating L. infantum in the Americas, and twelve studies fulfilled the inclusion criteria of this systematic review $[21,36,39,50,53,58,86,92,101,106,107,110]$. Most of the studies employed different 
PCR approaches in several tissues, although in one study the authors detected antibodies. Brazilian guinea pigs were reported to be infected in Brazil by PCR in heart tissue [86]. The infection was also found in two species of porcupines from Brazil: the prehensile tailed porcupine (Coendu-Sphiggurus villosus) by serology (DAT) [92], which is indirect evidence of the parasitism, and the Paraguayan hairy dwarf porcupine (Coendou-Sphiggurus spinosus) by PCR and sequencing from several tissues (Supplementary Materials File S4) [86]. Agouties were also reported to test positive for L. infantum in the spleen (16.7\%), skin and blood by PCR $[36,110]$. The giant rodent capybara (Hydrochoerus hydrochaeris) was positive in the lungs by PCR and sequencing [86]. Several species from wild mice, rats and cricetidae of the genera Cerradomys, Clyomis, Holochilus, Hylaeamys, Nectomys, Oryzomys, Proechymis, Rhipidomys and Trichomys were reported to be infected with L. infantum in several surveys, and in previous studies the potential role as reservoir of some of them was indicated [24]. The authors employed distinct approaches of PCR followed by RFLP, hybridisation or sequencing $[21,36,39,50,58,106,110]$.

Synanthropic rodents, such as the house mouse (Mus musculus), the black rat (Rattus rattus) and the brown rat (Rattus norvegiccus) were investigated in Brazil and Venezuela. Researchers found $20 \%$ of house mice to be infected [50], while the prevalence in black rats varied widely, with values from $0.1 \%$ to $100 \%$ using several approaches of PCR followed by hybridisation, RFLP or sequencing $[21,39,50,53,58,107]$. Almost $17 \%$ of brown rats were positive by nPCR and sequencing [50]. These synanthropic species of rodents could act as relevant reservoirs of leishmaniasis, since they were infected at high percentages and share habitats with humans.

Additional species were analysed in other surveys or in some of the previous studies in which the authors could not characterise the parasite at the species level (Supplementary Material File S4) [44,91,111-118]. Indirect evidence of Leishmania spp. was found in the USA using rapid tests (rk30 antigen) in several wild carnivores such as coyotes (Canis latrans, 1.6\%), American red foxes (Vulpes fulvus, 9.1\%) and grey foxes (Urocyon cinereoargenteus, $2 \%)[111,112]$. On the other hand, DNA of Leishmania spp. was detected in several species, including carnivores, such as South American grey foxes (Lycalopex-Pseudalopex griseus) [113] and Neotropical otters (Lontra longicaudis), and some species of primates, such as black-headed night monkeys (Aotus nigriceps), black-bearded sakis (Chiropotes satanas) and grey-woolly monkeys (Lagothrix cana) in Brazil [114]. Among rodents, Leishmania spp. DNA was reported in the blood of a red-tailed squirrel (Sciurus granatensis) in Venezuela [103].

Seventeen studies reported the infection in the red fox (Vulpes vulpes), with lower prevalence values found in France (9-15\%) and Georgia (2.6\%) and higher in southern European Mediterranean countries, such as Italy (12.3-40\%), Greece $(59.5 \%)$ or Spain (12-74\%) (Supplementary Materials File S5) [122,125,127-129,131,132,139-146]. The high numbers of publications might be due to the epidemiological relevance of this animal because it is a widespread species, which inhabit different ecosystems where the parasite life cycle can be completed, from forest to areas close to human settlements. One study carried out in Iran reported intermediate values (28.6\%) using serology, cultures, smears and PCR-sequencing from lymph nodes, skin and spleen [122]. Serology (ELISA, IFAT) was first employed in Italy [139] and then in Georgia (recombinant antigen rK39 rapid test) [120], but since 2000, PCR was the most widely used technique to detect the infection $[122,125,127-129,131,132,140-143,145,146]$. Although no clinical signs were reported in most of the studies, the majority of the animals from the study carried out in Greece (63.8\%) showed at least $2-3$ clinical signs compatible with canine VL including low weight, dermatitis, skin lesions, alopecia, esplenomegaly, enlargement of lymph nodes and onychogryphosis [143].

The infection was demonstrated also in Bennett's wallabies in a zoo in Madrid (Spain) using serology (rk39) and PCR followed by sequencing of the ITS1 and ITS2 regions. Thirtythree percent of the animals were infected in several tissues including blood, kidneys, lymph nodes, liver, lungs, skin and spleen [147]. In addition, two North West Bornean 
orangutan (Pongo pygmaeus) with clinical signs of visceral leishmaniasis were found to be infected using PCR (ITS1) of the bone marrow and serology [148].

Over the last decade, new reservoirs of leishmaniasis in Europe have been reinforced through investigation with bats, lagomorpha and hedgehog species, enlarging the list of wild animals infected with the parasite. Only one study in Europe demonstrated the presence of L. infantum in spleen, hair and blood of $51.9 \%$ common urban bats (Pipistrellus pipistrellus) in Spain, using PCR and sequencing of the repeat region [149]. One hundred percent of Algerian hedgehogs were found infected in two studies in Tunisia [150,151]. The authors employed smears, PCR and RFLP and sequencing of several targets. Spleen, liver, kidney, heart, lymph nodes, blood and eye swabs were positive to all of the techniques employed. In Spain, the European hedgehog was found to be infected using ELISA and qPCR of the kDNA region, finding higher values of infection in the spleen than in skin samples [137]. The parasite was also detected in a hair sample from one animal [131].

The DNA of L. infantum was first detected in 2013 in the spleen of European hares (Lepus europaeus) and Iberian hares (Lepus granatensis) from Spain, with $43.6 \%$ of the animals infected [152], since the outbreak of human leishmaniasis in Madrid motivated research on wild reservoirs. Since then, other studies were conducted finding the parasite in spleen, hair and skin with molecular (PCR of several targets), histological (direct antibody fluorescence assay) and serological analyses (IFAT) in Spain [153,154], Italy [155,156] and Greece [136]. Similar approaches were used for the European rabbit (Oryctolagus cuniculus), which was investigated in six studies from Spain $[128,129,153,154,157,158]$. The authors found positive values ranging from $0.6 \%$ to $59 \%$, depending on the time of the year, the sampling area or the techniques employed (i.e., smears, ELISA, IFAT, PCR). In general, serology displayed lower percentages of infection than PCR. In Italy and Greece, lower values of infected animals were obtained, but as previously pointed out, this might be due to the techniques employed (serology or PCR of ITS) [136,145].

Wild and synanthropic rodents were always the focus of researchers interested in L. infantum epidemiology, similar to what happened with other species of Leishmania. In Spain, the wood mouse (Apodemus sylvaticus) was positive with values of $20-50 \%$, depending on the study, in several tissues $[128,129,159]$. The authors employed culture and smears [159], but also PCR followed by RFLP or sequencing of ITS1, ITS2, kDNA and SSU regions. Blood and spleen from shrews (Crocidura russula) were found to be infected at a low prevalence [160] as well as Algerian mice (Mus spretus), in percetanges from $4.3 \%$ to $42.9 \%$ using PCR in several tissues as well as serology [137,160]. In Iran, 39\% of the sampled shor-tailed bandicoot rat (Nesokia indica) were positive in smears of skin and spleen, and later characterised as L. infantum by nested PCR of the kDNA when compared with reference isolates [161].

Synanthropic rodents were studied in eight surveys displaying high prevalence values for Leishmania infection. In most of them, L. infantum was found in the skin, liver and spleen of house mice (Mus musculus) and brown rats (Rattus norvegicus) in Portugal and Morocco [162,163], with animals displaying skin lesions in both studies. Smears were employed in Portugal while PCR and sequencing were employed in both studies, although different targets were selected (kDNA, ITS1, SSU). Prevalence values ranged from $22 \%$ to $33.3 \%$ in mice and $33 \%$ in rats. In Spain, $50 \%$ of house mice were found to test positive using PCR and sequencing of blood, bone-marrow and skin samples [159]. Brown rats were found infected using similar methologies, with $33-100 \%$ of animals positive in Spain $[129,131]$ and $5.9 \%$ in Greece [164]. Black rats (Rattus rattus) were found infected in $18.2 \%$ of sampled animals in Saudi Arabia [163], 15.5\% in Italy [165], 33.3\% in Spain [157] and 7.5\% in Morocco [161].

A summary of the techniques and organs found infected wit L. infantum in wild animals from Europe, Asia and Africa is summarised in Table 6. 


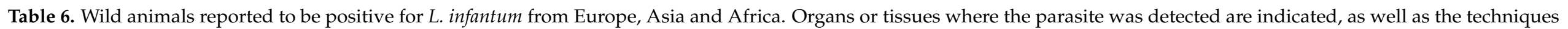
employed for detection.

\begin{tabular}{|c|c|c|c|c|c|}
\hline Host & Prevalence & Organs/Tissue Analysed & Methods for Detection & Country & References \\
\hline \multicolumn{6}{|l|}{ Order Carnivora } \\
\hline Canis aureus (golden jackal) & $3-11.6 \%$ & $\begin{array}{l}\text { blood, BM, liver, LN, } \\
\text { serum, spleen }\end{array}$ & $\begin{array}{c}\text { qPCR (ITS1), PCR (kDNA), IC rk39, smear, culture, PCR } \\
\text { ( } \alpha \text {-tubulin and GAPDH) }\end{array}$ & $\begin{array}{l}\text { Georgia, Israel, Iran } \\
\text { and Romania }\end{array}$ & [120-123] \\
\hline Canis lupus (grey wolf) & $6-100 \%$ & $\begin{array}{l}\text { blood, hair, liver, LN, skin, } \\
\text { serum, spleen }\end{array}$ & $\begin{array}{l}\text { PCR (cysteine protease B), qPCR (kDNA), PCR (kDNA) + RFLP, } \\
\text { PCR (ITS2) + RFLP, PCR (kDNA) + sequencing, ELISA }\end{array}$ & Croatia, Italy, Spain & [124-132] \\
\hline Felis silvestris (wildcat) & $25-100 \%$ & liver, LN, skin, spleen & $\begin{array}{c}\text { qPCR (kDNA), PCR (ITS2) + sequencing, PCR (kDNA) + } \\
\text { sequencing, qPCR (kDNA) + RFLP + sequencing }\end{array}$ & Spain & {$[127,128,133]$} \\
\hline Genetta genetta (common genet) & $10-100 \%$ & $\begin{array}{l}\text { blood, liver, skin } \\
\text { and spleen }\end{array}$ & $\begin{array}{c}\text { PCR (kDNA) + RFLP, qPCR (kDNA), PCR (ITS2) + sequencing, } \\
\text { PCR (kDNA) + sequencing, qPCR (kDNA) + RFLP + sequencing, } \\
\text { PCR (kDNA \& ITS2) + RFLP }\end{array}$ & Spain & $\begin{array}{c}{[125,127-} \\
129,133,134]\end{array}$ \\
\hline $\begin{array}{l}\text { Herpestes ichneumon } \\
\text { (Egyptian mongoose) }\end{array}$ & $4.7-28.6 \%$ & blood, spleen, & PCR (kDNA) + RFLP, PCR (kDNA) + sequencing, PCR (ITS1) & Spain, Portugal & {$[125,135]$} \\
\hline Lutra lutra (Eurasian otter) & $70 \%$ & spleen & PCR (kDNA) + sequencing & Spain & [127] \\
\hline Lynx pardinus (Iberian lynx) & $25 \%$ & blood, spleen, & PCR (kDNA) + RFLP & Spain & [125] \\
\hline Martes foina (beech marten) & $29-100 \%$ & $\begin{array}{l}\text { liver, LN, hair, skin and } \\
\text { spleen }\end{array}$ & $\begin{array}{c}\text { qPCR (kDNA), qPCR (ITS2) + sequencing, PCR (kDNA) + } \\
\text { sequencing, qPCR (kDNA) + sequencing, PCR (kDNA \& ITS2) + } \\
\text { RFLP }\end{array}$ & Spain & $\begin{array}{c}{[127-129,131} \\
133,137]\end{array}$ \\
\hline $\begin{array}{l}\text { Martes martes (European } \\
\text { pine marten) }\end{array}$ & $30-62 \%$ & blood, liver, spleen & $\begin{array}{c}\text { PCR (kDNA) + RFLP, qPCR (kDNA), qPCR (ITS2) + sequencing, } \\
\text { PCR (kDNA) + sequencing }\end{array}$ & Spain & {$[127,133,134]$} \\
\hline Meles meles (European badger) & $26-53 \%$ & liver, spleen & qPCR (kDNA), PCR (ITS2) + sequencing, PCR (kDNA) + & Spain, Italy & {$[132,133]$} \\
\hline Mustela lutreola (European Mink) & $2.1-50 \%$ & liver, spleen, serum & qPCR (kDNA), PCR (ITS2) + sequencing, PCR (ITS1), ELISA & Greece, Spain & {$[133,136]$} \\
\hline Mustela putorius (European polecat) & $25 \%$ & liver, spleen & qPCR (kDNA), PCR (ITS2) + sequencing & Spain & {$[133]$} \\
\hline Mustela vison (American mink) & $100 \%(n=1)$ & liver, spleen & qPCR (kDNA) & Spain & [137] \\
\hline Panthera tigris (Tiger) & $25 \%$ & $\begin{array}{l}\text { serum, LN and swab (oral, } \\
\text { conjunctival and nasal) }\end{array}$ & IFAT, qPCR & Italy & [138] \\
\hline Sciurus vulgaris (red squirrel) & $20 \%$ & liver, skin, pleen & qPCR (kDNA) & Spain & [137] \\
\hline Ursus arctos (brown bear) & $100 \%(n=1)$ & liver, skin, spleen & PCR (kDNA), PCR (ITS2) + RFLP & Spain & [129] \\
\hline Vulpes vulpes (red fox) & $2.6-74.6 \%$ & $\begin{array}{l}\text { blood, BM, hair, liver, LN, } \\
\text { skin, spleen, serum }\end{array}$ & $\begin{array}{c}\text { PCR (Repeat Region), PCR (kDNA), PCR (kDNA) + RFLP, qPCR } \\
\text { (kDNA), qPCR (ITS2) + sequencing, qPCR (ITS1) + RFLP, PCR } \\
\text { ( } \alpha \text {-tubulin and GAPDH) + sequencing, PCR (kDNA) + RFLP, } \\
\text { PCR (kDNA) + sequencing, PCR (ITS2) + RFLP, PCR (ITS1) + } \\
\text { sequencing, ELISA, IFAT, WB, IC rk39, smear, culture }\end{array}$ & $\begin{array}{l}\text { France, Georgia and } \\
\text { Greece, Iran, Italy } \\
\text { and Spain }\end{array}$ & $\begin{array}{l}{[120,122,125} \\
127-129,131 \\
132,139-146]\end{array}$ \\
\hline
\end{tabular}


Table 6. Cont

\begin{tabular}{|c|c|c|c|c|c|}
\hline Host & Prevalence & Organs/Tissue Analysed & Methods for Detection & Country & References \\
\hline \multicolumn{6}{|l|}{ Order Chiroptera } \\
\hline $\begin{array}{l}\text { Pipistrellus pipistrellus (common } \\
\text { urban bat) }\end{array}$ & $59.2 \%$ & blood clot, hair, spleen & PCR (Repeat region) + sequencing & Spain & [149] \\
\hline \multicolumn{6}{|l|}{ Order Diprotodontia } \\
\hline $\begin{array}{l}\text { Macropus rufogriseus } \\
\text { (Bennett's wallaby) }\end{array}$ & $33.3 \%$ & $\begin{array}{l}\text { blood, BM, liver, lung, } \\
\text { LN, kidney, skin, spleen }\end{array}$ & PCR (ITS1 and ITS2) + sequencing, IC rk39 & Spain & [147] \\
\hline Atelerix algirus (Algerian hedgehog) & $100 \%$ & $\begin{array}{l}\text { blood, eye swab, heart, } \\
\text { kidney, liver, LN, } \\
\text { skin, spleen }\end{array}$ & $\begin{array}{c}\text { PCR (kDNA), PCR (ITS1), PCR (mini-exon), PCR (Repeat region), } \\
\text { PCR (SSU), smear }\end{array}$ & Tunisia & {$[150,151]$} \\
\hline $\begin{array}{l}\text { Erinaceus europaeus (European } \\
\text { hedgehog) }\end{array}$ & $34.4-100 \%$ & hair, serum, skin, spleen & qPCR (kDNA), ELISA & Spain & {$[131,137]$} \\
\hline \multicolumn{6}{|l|}{ Order Lagomorpha } \\
\hline Lepus europaeus (European hare) & $0.9-43.6 \%$ & blood, spleen, serum & $\begin{array}{c}\text { PCR (kDNA) + RFLP, PCR (ITS1), PCR (ITS1) + sequencing, } \\
\text { ELISA, IFAT }\end{array}$ & $\begin{array}{l}\text { Greece, Italy } \\
\text { and Spain }\end{array}$ & $\begin{array}{l}{[136,152,155,} \\
156]\end{array}$ \\
\hline $\begin{array}{l}\text { Oryctolagus cuniculus } \\
\text { (European rabbit) }\end{array}$ & $0.6-59 \%$ & $\begin{array}{l}\text { blood, BM, hair, heart, } \\
\text { liver, LN, skin, spleen, } \\
\text { serum }\end{array}$ & $\begin{array}{l}\text { qPCR (kDNA), PCR (ITS1) + RFLP, ELISA, nPCR (SSU), qPCR } \\
\text { (kDNA) + RFLP + sequencing, PCR (kDNA) + RFLP, PCR (ITS2) } \\
\text { + RFLP, PCR (ITS1), smears, culture, IFAT, DFA, ELISA, IC rk39 }\end{array}$ & $\begin{array}{l}\text { Greece, Italy } \\
\text { and Spain }\end{array}$ & $\begin{array}{l}{[128,129,136} \\
145,153,154 \\
157,158]\end{array}$ \\
\hline \multicolumn{6}{|l|}{ Order Primates } \\
\hline $\begin{array}{l}\text { Pongo pygmaeus (north west } \\
\text { Bornean orangutan) }\end{array}$ & $100 \%$ & $\mathrm{BM}$, serum & Microscopy, IFAT, nPCR (ITS1) & Spain & [148] \\
\hline
\end{tabular}


Table 6. Cont.

\begin{tabular}{|c|c|c|c|c|c|}
\hline Host & Prevalence & Organs/Tissue Analysed & Methods for Detection & Country & References \\
\hline \multicolumn{6}{|l|}{ Order Rodentia } \\
\hline Apodemus sylvaticus (wood mouse) & $20-50 \%$ & $\begin{array}{l}\text { blood, BM, liver, skin, } \\
\text { spleen }\end{array}$ & $\begin{array}{l}\text { PCR (ITS1) + sequencing, PCR-ELISA (kDNA), qPCR (kDNA) + } \\
\text { RFLP + sequencing, PCR (ITS2) + RFLP, smear, culture }\end{array}$ & Spain & {$[128,129,159]$} \\
\hline $\begin{array}{c}\text { Crocidura russula } \\
\text { (white-toothed shrew) }\end{array}$ & $13.3 \%$ & blood and/or spleen & qPCR $(\mathrm{kDNA})$ & Spain & [160] \\
\hline Mus musculus (house mouse) & $22-50 \%$ & $\begin{array}{l}\text { blood, BM, liver, } \\
\text { skin, spleen }\end{array}$ & $\begin{array}{l}\text { qPCR (kDNA) + sequencing, PCR (ITS1) + sequencing, } \\
\text { PCR-ELISA (kDNA), nPCR (SSU and ITS1) + sequencing, smear }\end{array}$ & $\begin{array}{l}\text { Morocco, Portugal } \\
\text { and Spain }\end{array}$ & {$[162,163]$} \\
\hline $\begin{array}{l}\text { Nesokia indica } \\
\text { (short-tailed bandicoot rat) }\end{array}$ & $39 \%$ & liver, skin, spleen, & nPCR (kDNA), smear & Iran & [162] \\
\hline Rattus norvegicus (brown rat) & $5.9-100 \%$ & hair, liver, skin, spleen & $\begin{array}{l}\text { nPCR (SSU), nPCR (ITS1) + sequencing, qPCR (kDNA), PCR } \\
\text { (kDNA), PCR (kDNA) + RFLP, PCR (ITS2) + RFLP, smear }\end{array}$ & $\begin{array}{l}\text { Greece, Morocco, } \\
\text { Portugal and Spain }\end{array}$ & $\begin{array}{c}{[129,131,162} \\
163,166]\end{array}$ \\
\hline Rattus rattus (black rat) & $7.5-33.3 \%$ & $\begin{array}{l}\text { blood, BM, liver, } \\
\text { skin, spleen }\end{array}$ & $\begin{array}{l}\text { PCR (kDNA) + sequencing, PCR (ITS1) + sequencing, } \\
\text { PCR-ELISA (kDNA), nPCR (SSU), nPCR (ITS1) + sequencing, } \\
\text { smear, culture, inoculation to hamster, isoenzymes }\end{array}$ & $\begin{array}{l}\text { Italy, Morocco, Saudi } \\
\text { Arabia and Spain }\end{array}$ & {$[159,163-165]$} \\
\hline
\end{tabular}

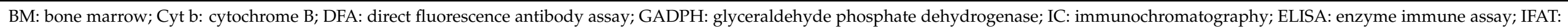

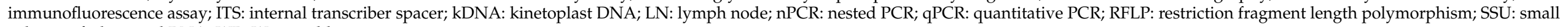
subunit of ribosomal RNA; WB: Western blot. 
In previous reviews, other species were reported infected with L. infantum or were described as clinical cases: domestic ferrets (Mustela putorius furo), corsac foxes (Vulpes corsak), raccoon dogs (Nyctereutes procyonoides), Mediterranean monk seals (Monachus monachus), Persian jirds (Meriones persicus), Syrian hamsters (Mesocricetus auratus), grey hamsters (Cricetulus migratorius) and porcupines (Hystrix sp.). Detailed information can be found in specific reviews $[19,26,27]$.

\subsection{Wild Animals Infected with L. major}

L. major infections extended through Asian and African countries [3,5], and nineteen studies were carried out from 1990 in wild animals in Algeria, Tunisia, Iran, Israel, Ethiopia, Kenya, Cameroon and Morocco (Supplementary Materials File S5).

In the included studies, the most employed techniques to detect L. major were PCR of the kDNA (nine studies) and ITS (nine studies) regions, although SSU and the repeat regions were also employed, mainly followed by RFLP and/or sequencing (four and two studies, respectively). Only seven studies exclusively employed the skin to search for the parasite, but the rest of the studies employed also other anatomical sites such as liver, spleen, heart, blood, kidney, lymph nodes, eye swabs or even feces. Noteworthy were the higher prevalence values observed in smears compared with the PCR of the kDNA in some studies, probably due to the methodology employed, since the DNA was extracted from fixed smears [161,167-171] (for details, see Supplementary Materials File S5).

The infection was demonstrated in the orders Chiroptera, Eulipotyphla, Primates, and Rodentia, the last group, again, being the most widely studied. Only one species of bat (Nycteris hispida) was reported in Ethiopia to be infected with L. major in the spleen by qPCR and sequencing of the kDNA and ITS regions [172]. The DNA of the parasite was found in several organs and tissues in three species of hedgehogs in Algeria, Iran and Tunisia including spleen, skin, heart, kidney, liver, blood and eye swab. A hundred percent prevalence was reported in two studies carried out on the Algerian hedgehog (Atelerix algirus) in Tunisia [150,151], while 36.8\% was reported in Algeria by serology and PCRRFLP of the kDNA region employing the spleen and skin [173] (Supplementary Materials File S5). Two studies, including the long-eared hedgehog (Hemiechinus auritus), reported prevalence rates ranging from 33\%, using nPCR of the ITS and smears of the skin [173], to $53.3 \%$, employing nPCR of the kDNA from the skin and smears from skin, liver and spleen [174]. The desert hedgehog (Paraechinus aethiopicus) was found to be infected with L. major in two studies. The first study employed qPCR of the kDNA region from spleen and skin as well as serology [175], and the other reported the infection in the kidney, blood, liver, eye swab and lymph node of one animal by qPCR of the kDNA, SSU and repeat regions [151]. The high values of infection found in these animals suggest their role as reservoirs, and these animals should be monitored in endemic areas.

One study investigated the immune response to L. major of three species of primates in Kenya (Cercopithecus mitis, Chlorocebus aethiops and Papio cynocephalus anubis) including humoral (ELISA and Western blot) and cellular responses (lymphoproliferative assay) [176]. The authors include 57-213 individuals per technique and found that $60-77 \%$ of the animals were previously exposed to the parasite. Surprinsingly, one study found parasites (amastigote and promastigotes forms) and DNA of L. major in the feces of gorillas (Gorilla gorilla) in Cameroon, and the authors pointed to the ingestion of phlebotomines by the animals [15]. However, no other method to measure exposure (serology) or presence of the parasite in organs was employed.

Eleven species of rodents were reported as infected with the parasite in nine studies from Iran, and another one from Israel (Supplementary Materials File S5), following the same tendency of other zoonotic species of Leishmania included in the systematic review. The higher prevalence was found in Meriones libycus by PCR of kDNA in the skin [177], which is also the species most studied regarding Leishmania infections in Iran [167-171,173,177,178]. Other species of Meriones (M. hurrianae, M. persicus and $M$ tristrami) and Microtus (M. guentheri and M. socialis) were reported to be infected with 
parasites with values of 5.7-58.3\% [161,168,171,179]. Mus musculus was found to be infected with low percentages of infection (2.3-33\%) in three studies carried out in Iran and Israel. However, PCR of the ITS region from skin samples, and smears from skin, liver and spleen, were used instead of PCR of kDNA, [161,179]. Nesokia indica was found to be infected in three studies from Iran, ranging from $8 \%$ in skin by smears and PCR of the ITS region [168] to values higher than 61\% employing smears and PCR of skin, liver and spleen tissues [161,167]. The same techniques (PCR of the ITS and kDNA regions) were employed in three studies in Iran to detect L. major infections in Tatera indica from skin, liver or spleen, with values of prevalence ranging from 3,7 to 50\% [168,171,178]. The great gerbil (Rhombomys opimus) was reported infected with the parasite in Iran [168,178] using smears, PCRs and inoculation of hamsters (see Supplementary Materials File S5 for details). The high prevalence found in many of these rodent species points to their reservoir role.

Most of the studies did not find clinical signs in infected animals, or the authors did not look for them; however, skin lesions were recorded in Meriones libycus from Iran [177].

All the information concerning L. major infection in wild animals is summarised in Table 7.

In previous reviews, other species were reported infected with L. major in the past including primates (Cercopithecus aethiops) and rodents (Xerus rutilus, Gerbillus pyramidum, Tatera gambiana, Tatera robusta, Taterillus emini, Meriones crassus, Meryones meridianus, Meryones shawi, Psammomis obesus, Praomys erythroleucus and Mastomys natalensis) [23].

\subsection{Wild Animals Infected with Leishmania tropica}

Four studies conducted in Ethiopia [175,180], Kenya [181] and Egypt [182] demonstrated the presence of L. tropica DNA in the spleen of rodents and bats. One hundred and sixty-three bats (Cardioderma cor) were analyzed in Ethiopia by qPCR of the kDNA and ITS1 regions and $4.9 \%$ were found to be infected [175]. Using the same techniques, the authors found prevalences from $9.9 \%$ to $20 \%$ in the rodents Acomys sp. Arvicanthis niloticus and Gerbillus nanus [180] (Supplementary Materials File S5). In Egypt, L. tropica was found in $14.3 \%$ of the analyzed Anderson's gerbils (Gerbillus andersoni) with clinical signs by smears and PCR of the ITS1 region [182]. Finally, employing nested PCR and sequencing of the SSU and the ITS1 regions, 22\% of the sampled house mice (skin) were found infected with L. tropica in Morocco [163].

The species Procavia capensis and Arvicanthis niloticus were reported in previous reviews infected with L. tropica [23]. 
Table 7. Wild animals reported positive for L. major. Organs or tissues where the parasite was detected, and the techniques employed are indicated.

\begin{tabular}{|c|c|c|c|c|c|}
\hline Host & Prevalence & Organs/Tissue Analysed & Methods for Detection & Country & References \\
\hline \multicolumn{6}{|l|}{ Order Chiroptera } \\
\hline Nycteris hispida & $100 \%(n=1)$ & spleen & qPCR (kDNA and ITS1) + sequencing & Ethiopia & [172] \\
\hline \multicolumn{6}{|l|}{ Order Eulipotyphla } \\
\hline Atelerix algirus (Algerian hedgehog) & $36.8-100 \%$ & $\begin{array}{l}\text { blood, eye swab, heart, kidney, } \\
\text { liver, LN, skin, spleen }\end{array}$ & $\begin{array}{c}\text { qPCR (kDNA), PCR (kDNA), PCR (ITS1) + RFLP, nPCR (kDNA), } \\
\text { PCR (ITS1) + sequencing + RFLP, PCR (mini-exon) + sequencing + } \\
\text { RFLP, nPCR (Repeat region) + sequencing + RFLP, PCR (SSU) + } \\
\text { sequencing, smear, ELISA, WB }\end{array}$ & Algeria, Tunisia & {$[150,151,175]$} \\
\hline $\begin{array}{l}\text { Hemiechinus auritus } \\
\text { (long-eared hedgehogs) }\end{array}$ & $33.3-53.3 \%$ & liver, skin, spleen & nPCR (ITS1) + sequencing, nPCR (kDNA), semi-nPCR (kDNA), smear & Iran & {$[173,174]$} \\
\hline Paraechinus aethiopicus (desert hedgehog) & $40-100 \%$ & $\begin{array}{l}\text { blood, eye swab, kidney, liver, } \\
\text { LN, skin, spleen, serum }\end{array}$ & $\begin{array}{c}\text { qPCR (kDNA), PCR (ITS1) + RFLP, PCR (kDNA and SSU) + } \\
\text { sequencing, nPCR (Repeat region) + RFLP + sequencing, ELISA, WB }\end{array}$ & Algeria, Tunisia & {$[151,175]$} \\
\hline \multicolumn{6}{|l|}{ Order Primates } \\
\hline Cercopithecus mitis (syke's monkeys) & $67.2 \%$ & serum & ELISA, WB & Kenya & [176] \\
\hline Chlorocebus aethiops (vervet monkeys) & $60.6 \%$ & serum & ELISA, WB, lymphocyte proliferation assay & Kenya & [176] \\
\hline Gorilla gorilla (gorilla) & $13.2 \%$ & faeces & $\begin{array}{c}\text { qPCR (SSU), qPCR (SSU) + sequencing, PCR (ITS) + sequencing, } \\
\text { PCR (Cytb) + sequencing }\end{array}$ & Cameroon & {$[15]$} \\
\hline Papio cynocephalus anubis (olive baboons) & $77.2 \%$ & serum & ELISA, WB & Kenya & [176] \\
\hline \multicolumn{6}{|l|}{ Order Rodentia } \\
\hline Meriones hurrianae & $7.7 \%$ & liver, skin, spleen & PCR (kDNA), smear & Iran & [171] \\
\hline Meriones libycus & $5.7-100 \%$ & liver, skin, spleen & $\begin{array}{c}\text { PCR (kDNA), nPCR (ITS1), PCR (ITS1) + RFLP + sequencing, } \\
\text { semi-nPCR (kDNA), PCR (Cytb) + sequencing, nPCR (ITS1) + } \\
\text { sequencing, nPCR (ITS2) + RFLP, smear, inoculation to hamster, } \\
\text { inoculation to BALB / c mice }\end{array}$ & Iran & $\begin{array}{c}{[167-170,173,} \\
177,178]\end{array}$ \\
\hline Meriones persicus & $33 \%$ & skin & PCR (ITS1) + RFLP + sequencing, smear & Iran & [168] \\
\hline Meriones tristrami & $58.3 \%$ & skin & PCR (ITS1) + RFLP & Israel & [179] \\
\hline Microtus guentheri & $16.5 \%$ & skin & PCR (ITS1) + RFLP & Israel & [179] \\
\hline Microtus socialis & $50 \%$ & liver, skin, spleen & smear & Iran & [161] \\
\hline Mus musculus (house mouse) & $2.3-33 \%$ & liver, skin, spleen & PCR (ITS1) + RFLP, smear & Israel, Morocco and Iran & {$[161,179]$} \\
\hline Nesokia indica & $8-63.4 \%$ & liver, skin, spleen & $\begin{array}{l}\text { PCR (ITS1) + RFLP + sequencing, PCR (kDNA), nPCR (kDNA), smear } \\
\text { PCR (ITS1) + RFLP + sequencing, semi-nPCR (kDNA), PCR (Cytb) + }\end{array}$ & Iran & {$[161,167,168]$} \\
\hline Rhombomys opimus (great gerbil) & $13.4-35 \%$ & skin & $\begin{array}{l}\text { sequencing, smear, IHC, inoculation to hamster, inoculation to } \\
\text { BALB } / \mathrm{c} \text { mice }\end{array}$ & Iran & {$[168,169]$} \\
\hline Tatera indica & $3.7-50 \%$ & liver, skin, spleen & $\begin{array}{c}\text { PCR (kDNA), PCR (ITS1) + RFLP + sequencing, semi-nPCR (kDNA) } \\
\text { + sequencing, PCR (Cytb), smear }\end{array}$ & Iran & {$[168,169,171]$} \\
\hline
\end{tabular}

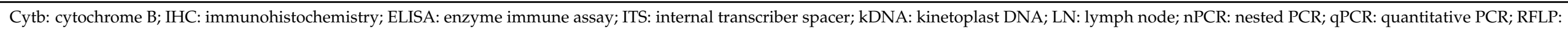
restriction fragment length polymorphism; SSU: small subunit of ribosomal RNA; WB: Western blot. 


\subsection{Wild Animals Infected with Leishmania donovani}

In Africa, rodents were infected with $L$. donovani in three studies. One employed serology and found $5.5 \%$ of African grass rats (Arvicanthis niloticus) to be positive by ELISA in Sudan [183], while another study found $18.2 \%$ of black rats (Rattus rattus) with clinical signs carrying the parasite in Saudi Arabia [164], employing culture, smear and inoculation of hamster. The other study found DNA of the L. donovani complex in the spleen in 15.3\% of Mastomys erythroleucus, 7.7\% of Gerbilliscus nigricaudus and 17.4\% of Arvicanthis niloticus from Ethiopia using PCR of the kDNA and ITS regions [180].

Finally, one study obtained a prevalence of $23.5 \%$ of the L. donovani complex in European hares from Greece by nested PCR of the ITS region, employing the spleen of 166 animals [184] (Supplementary Materials File S5).

Details of infection with $L$. donovani of Felis serval can be found in a previous review [23].

Some of the previously mentioned studies obtained positive results for Leishmania spp., but they could not further determine the species (see Supplementary Materials File S5). The spleen of other four species of bats (Glauconycteris variegate, Miniopterus arenarius, Neoromicia somalica and Scotophilus colias) were found to be infected with Leishmania spp. in Ethiopia by PCR [175]. In a similar approach, $40 \%$ of the analyzed rodents of Aethomys spp. were also positive [180]. Smears of liver and spleen and indirect haemagglutination test were employed to detect the parasite in $40 \%$ of the sand cat (Felis margarita) in Saudi Arabia [185]. The same techniques were employed to detect Leishmania spp. infections in Gerbillus pyramidum and Rattus norvegicus in Egypt [186].

In previous reviews, other species of mammals, such as Crycetomys gambianus, Heterohyrax brucei and Dendrohyrax arboreus, were reported to be infected with L. aethiopica [23].

\section{Conclusions}

Knowledge of the role of wild animals as suitable hosts or reservoirs of Leishmania zoonotic species is essential in order to apply control measues or monitoring programmes. In this review, a systematic search of wild animals infected with zoonotic species of Leishmania was conducted, starting from 1990 and following PRISMA methodology. One hundred and eighty-nine species of wild animlas from ten orders (i.e., Carnivora, Chiroptera, Cingulata, Didelphimorphia, Diprotodontia, Lagomorpha, Eulipotyphla, Pilosa, Primates and Rodentia) were included in the review. Rodents and carnivores were the orders more widely explored, being the most probable main reservoirs, and also the ones presenting more clinical signs. L. infantum was the most widely distributed species, both geographically and in the range of species, followed by L. (Viannia) braziliensis, but this fact could be due to the more exhaustive investigation on these species.

More studies on the role of infected wild animals are necessary in order to implement specific measures when an outbreak of the disease appears.

Supplementary Materials: The following are available online at https:/ /www.mdpi.com/article/10 $.3390 /$ microorganisms9051101/s1, Supplementary File S1: Detailed information on wild animals infected with Leishmania (Viania) spp.; Supplementary File S2: Detailed information on wild animals infected with Leishmania amazonensis; Supplementary File S3: Detailed information on wild animals infected with Leishmania mexicana; Supplementary File S4: Detailed information on wild animals infected with Leishmania infantum in the Americas; Supplementary File S5: Detailed information on wild animals infected with Leishmania spp. from Europe, Africa and Asia.

Author Contributions: Conceptualisation, R.A.M.-D., I.A.-C. and M.T.G.-M.; Methodology, M.T.G.M. and I.A.-C.; Software, R.A.M.-D., I.A.-C. and M.T.G.-M.; Validation, R.A.M.-D., I.A.-C. and M.T.G.-M.; Formal Analysis, R.A.M.-D., I.A.-C. and M.T.G.-M.; Investigation, R.A.M.-D., I.A.-C. and M.T.G.-M.; Resources, R.A.M.-D., I.A.-C. and M.T.G.-M.; Data Curation, R.A.M.-D., I.A.-C. and M.T.G.-M.; Writing-Original Draft Preparation, R.A.M.-D., I.A.-C. and M.T.G.-M.; WritingReview and Editing, R.A.M.-D., I.A.-C. and M.T.G.-M.; Validation: R.A.M.-D., I.A.-C. and M.T.G.-M.; Supervision, R.A.M.-D. and M.T.G.-M. All authors have read and agreed to the published version of the manuscript. 
Funding: This research received no external funding.

Conflicts of Interest: The authors declare no conflict of interest.

\section{References}

1. Maxfield, L.; Crane, J.S. Leishmaniasis; StatPearls Pulblishing: Treasure Island, FL, USA, 2019. Available online: https://www.ncbi. nlm.nih.gov / books /NBK531456/ (accessed on 6 September 2020).

2. Bern, C.; Maguire, J.H.; Alvar, J. Complexities of assessing the disease burden attributable to leishmaniasis. PLoS Negl. Trop. Dis. 2008, 2, e313. [CrossRef]

3. World Health Organization. Leishmaniasis Situation and Trends; Global Health Observatory data; World Health Organization: Geneva, Switzerland, 2018.

4. Akhoundi, M.; Kuhls, K.; Canne, A.; Votýpka, J.; Marty, P.; Delaunay, P.; Sereno, D. A Historical Overview of the Classification, Evolution, and Dispersion of Leishmania Parasites and Sandflies. PLoS Negl. Trop. Dis. 2016, 10, e0004349. [CrossRef] [PubMed]

5. Akhoundi, M.; Downing, T.; Votýpka, J.; KKuhls, K.; Lukeš, J.; Cannet, A.; Ravel, C.; Marty, P.; Delaunay, P.; Kasbari, M.; et al. Leishmania Infections: Molecular Targets and Diagnosis. Mol. Asp. Med. 2017, 57, 1-29. [CrossRef] [PubMed]

6. Schönian, G.; Mauricio, I.; Cupolillo, E. Is it time to revise the nomenclature of Leishmania? Trends Parasitol. 2010, 26, 466-469. [CrossRef]

7. Pruzinova, K.; Sadlova, J.; Seblova, V.; Homola, M.; Votypka, J.; Volf, P. Comparison of bloodmeal digestion and the peritrophic matrix in four sand fly species differing in susceptibility to Leishmania donovani. PLoS ONE 2015, 10, e0128203. [CrossRef] [PubMed]

8. World Health Organization. Control of the Leishmaniases; WHO Technical Report Series; World Health Organization: Geneva, Switzerland, 2010; pp. 1-186.

9. Naucke, T.J.; Lorentz, S. First Report of Venereal and Vertical Transmission of Canine Leishmaniosis from Naturally Infected Dogs in Germany. Parasit. Vectors 2012, 5, 1-5. [CrossRef] [PubMed]

10. Guedes, D.L.; van Henten, S.; Cnops, L.; Adriaensen, W.; Johan Griensven, J. Sexual Transmission of Visceral Leishmaniasis: A Neglected Story. Trends Parasitol. 2020, 36, 950-952. [CrossRef]

11. Naucke, T.J.; Amelung, S.; Lorentz, S. First Report of Transmission of Canine Leishmaniosis through Bite Wounds from a Naturally Infected Dog in Germany. Parasit. Vectors 2016, 9, 1-4. [CrossRef]

12. Coutinho, M.T.Z.; Linardi, P.M. Can Fleas from Dogs Infected with Canine Visceral Leishmaniasis Transfer the Infection to Other Mammals? Vet. Parasitol. 2007, 147, 320-325. [CrossRef]

13. Lainson, R. Ecological Interactions in the Transmission of the Leishmaniases. Phil. Trans. R. Soc. Lond. Ser. B Biol. Sci. 1988, 321, 389-404. [CrossRef]

14. De Oliveira, F.M.; Costa, L.H.C.; de Barros, T.L.; Ito, P.K.R.K.; Colombo, F.A.; Carvalho, C.; Pedro, W.A.; Queiroz, L.H.; Nunes, C.M. First Detection of Leishmania Spp. DNA in Brazilian Bats Captured Strictly in Urban Areas. Acta Trop. 2015, 150, 176-181. [CrossRef]

15. Hamad, I.; Forestier, C.L.; Peeters, M.; Delaporte, E.; Raoult, D.; Bittar, F. Wild Gorillas as a Potential Reservoir of Leishmania major. J. Infect. Dis. 2015, 211, 267-273. [CrossRef]

16. Rescigno, M.; Urbano, M.; Valzasina, B.; Francolín, M.; Rotta, G.; Bonasio, R.; Granucci, F.; Kraehenbuhl, J.-P.; Ricciardi-Castagnoli, P. Dendritic cells express tight junction proteins and penetrate gut epithelial monolayers to sample bacteria. Nat. Immunol. 2001, 2, 361-367. [CrossRef]

17. Rodríguez, J.M. The origin of human milk bacteria: Is there a bacterial entero-mammary pathway during late pregnancy and lactation? Adv. Nutr. 2014, 5, 779-784. [CrossRef]

18. World Health Organization. Leishmaniasis Facksheet. Available online: https://www.who.int/en/news-room/fact-sheets/ detail/leishmaniasis (accessed on 8 January 2021).

19. Cardoso, L.; Schallig, H.; Persichetti, M.F.; Pennisi, M.G. New Epidemiological Aspects of Animal Leishmaniosis in Europe: The Role of Vertebrate Hosts Other than Dogs. Pathogens 2021, 10, 307. [CrossRef]

20. Miró, G.; Müller, A.; Montoya, A.; Checa, R.; Marino, V.; Marino, E.; Fuster, F.; Escacena, C.; Descalzo, M.A.; Gálvez, R. Epidemiological Role of Dogs since the Human Leishmaniosis Outbreak in Madrid. Parasit. Vectors 2017, 10, 209. [CrossRef]

21. Quaresma, P.F.; Rego, F.D.; Botelho, H.A.; da Silva, S.R.; Moura, A.J., Jr.; Teixeira Neto, R.G.; Madeira, F.M.; Carvalho, M.B.; Paglia, A.P.; Melo, M.N.; et al. Wild, synanthropic and domestic hosts of Leishmania in an endemic area of cutaneous leishmaniasis in Minas Gerais State, Brazil. Trans. R. Soc. Trop. Med. Hyg. 2011, 105, 579-585. [CrossRef]

22. World Health Organization. Control of the Leishmaniases: Report of a WHO Expert Committee; WHO Report Series; World Health Organization: Geneva, Switzerland, 1990; Volume 793.

23. Ashford, R.W. Leishmaniasis Reservoirs and Their Significance in Control. Clin. Dermatol. 1996, 14, 523-532. [CrossRef]

24. Roque, A.L.R.; Jansen, A.M. Wild and Synanthropic Reservoirs of Leishmania Species in the Americas. Int. J. Parasitol. Parasit. Wildl. 2014, 3, 251-262. [CrossRef]

25. Souza, T.D.; Turchetti, A.P.; Fujiwara, R.T.; Paixão, T.A.; Santos, R.L. Visceral Leishmaniasis in Zoo and Wildlife. Vet. Parasitol. 2014, 200, 233-241. [CrossRef]

26. Millán, J.; Ferroglio, E.; Solano-Gallego, L. Role of Wildlife in the Epidemiology of Leishmania infantum infection in Europe. Parasitol. Res. 2014, 113, 2005-2014. [CrossRef] [PubMed] 
27. Quinnell, R.J.; Courtenay, O. Transmission, reservoir hosts and control of zoonotic visceral leishmaniasis. Parasitology 2009, 136, 1915-1934. [CrossRef] [PubMed]

28. Page, M.J.; McKenzie, J.E.; Bossuyt, P.M.; Boutron, I.; Hoffmann, T.C.; Mulrow, C.D.; Shamseer, L.; Tetzlaff, J.M.; Akl, E.A.; Brennan, S.E.; et al. The PRISMA 2020 statement: An updated guideline for reporting systematic reviews. PLoS Med. 2021, 18, e1003583. [CrossRef] [PubMed]

29. Alexander, B.; Lozano, C.; Barker, D.C.; McCann, S.H.E.; Adler, G.H. Detection of Leishmania (Viannia) braziliensis Complex in Wild Mammals from Colombian Coffee Plantations by PCR and DNA Hybridization. Acta Trop. 1998, 69, 41-50. [CrossRef]

30. Brandão-Filho, S.P.; Brito, M.E.; Carvalho, F.G.; Ishikaw, E.A.; Cupolillo, E.; Floeter-Winter, L.; Shaw, J.J. Wild and Synanthropic Hosts of Leishmania (Viannia) braziliensis in the Endemic Cutaneous Leishmaniasis Locality of Amaraji, Pernambuco State, Brazil. Trans. R. Soc. Trop. Med. Hyg. 2003, 97, 291-296. [CrossRef]

31. Tonelli, G.B.; Tanure, A.; Rego, F.D.; Carvalho, G.M.L.; Stumpp, R.; Ássimos, G.R.; Campos, A.M.; Lima, A.C.V.M.; Gontijo, C.M.F.; Paz, G.F.; et al. Leishmania (Viannia) braziliensis Infection in Wild Small Mammals in Ecotourism Area of Brazil. PLoS ONE 2017, 12, e0190315. [CrossRef]

32. Lucas, J.; Lourenço, M.; Minuzzi-souza, T.T.C.; Silva, L.R.; Oliveira, A.M. High Frequency of Trypanosomatids in Gallery Forest Bats of a Neotropical Savanna. Acta Trop. 2018, 177, 200-206.

33. De Lima, H.; De Guglielmo, Z.; Rodriguez, A.; Convit, J.; Rodriguez, N. Cotton rats (Sigmodon hispidus) and black rats (Rattus rattus) as possible reservoirs of Leishmania spp. in Lara State, Venezuela. Mem. Inst. Oswaldo Cruz 2002, 97, 169-174. [CrossRef]

34. Trüeb, I.; Portela, R.D.; Franke, C.R.; Carneiro, I.O.; Ribeiro, G.J.; Soares, R.P.; Barrouin-Melo, S.M. Trypanosoma cruzi and Leishmania sp. Infection in Wildlife from Urban Rainforest Fragments in Northeast Brazil. J. Wildl. Dis. 2018, 54, 76-84. [CrossRef]

35. Cardoso, R.M.; De Araújo, N.S.L.; Romero, G.A.S.; Souza, T.T.C.M.; Dietrich, A.G.; Mendes, J.D.; Reis, M.L.; Ferreira, J.B.C.; Hecht, M.M.; Gurgel-Gonçalves, R. Expanding the Knowledge about Leishmania Species in Wild Mammals and Dogs in the Brazilian Savannah. Parasit. Vectors 2015, 8, 171. [CrossRef]

36. Cássia-Pires, R.; Boité, M.C.; D’Andrea, P.S.; Herrera, H.M.; Cupolillo, E.; Jansen, A.M.; Roque, A.L.R. Distinct Leishmania Species Infecting Wild Caviomorph Rodents (Rodentia: Hystricognathi) from Brazil. PLoS Negl. Trop. Dis. 2014, e3389. [CrossRef]

37. Voltarelli, E.M.; Arraes, S.M.A.A.; Perles, T.F.; Lonardoni, M.V.C.; Teodoro, U.; Silveira, T.G.V. Serological survey for Leishmania sp. Infection in wild animals from the municipality of Maringá, Paraná state, Brazil. J. Venom. Anim. Toxins Incl. Trop. Dis. 2009, 15, 732-744. [CrossRef]

38. Schallig, H.D.F.H.; da Silva, E.S.; van der Meide, W.F.; Schoone, G.J.; Contifjo, C.M.F. Didelphis marsupialis (Common Opossum): A Potential Reservoir Host for Zoonotic Leishmaniasis in the Metropolitan Region of Belo Horizonte (Minas Gerais, Brazil). Vector Borne Zoonotic Dis. 2007, 7, 387-393. [CrossRef]

39. Lima, B.S.; Dantas-Torres, F.; de Carvalho, M.R.; Marinho-Junior, J.F.; de Almeida, E.L.; Brito, M.E.; Gomes, F.; Brandão-Filho, S.P. Small mammals as hosts of Leishmania spp. in a highly endemic area for zoonotic leishmaniasis in North-Eastern Brazil. Trans. R. Soc. Trop. Med. Hyg. 2013, 107, 592-597. [CrossRef]

40. Aransay, A.M.; Scoulica, E.; Tselentis, Y. Detection and identification of Leishmania DNA within naturally infected sand flies by seminested PCR on minicircle kinetoplastic DNA. Appl. Environ. Microbiol. 2000, 66, 1933-1938. [CrossRef]

41. Telleria, J.; Bosseno, M.F.; Tarifa, T.; Buitrago, R.; Martinez, E.; Torrez, M.; Le Pont, F.; Brenière, S.F. Putative reservoirs of Leishmania amazonensis in a Sub-Andean focus of Bolivia identified by kDNA-polymerase chain reaction. Mem. Inst. Oswaldo Cruz 1999, 94, 5-6. [CrossRef]

42. Shapiro, J.T.; da Costa Lima Junior, M.S.; Dorval, M.E.; de Oliveira, F.A.; Cepa Matos, M.F.; Bordignon, M.O. First record of Leishmania braziliensis presence detected in bats, Mato Grosso do Sul, southwest Brazil. Acta Trop. 2013, 128, 171-174. [CrossRef]

43. Castro Ferreira, E.; Pereira, A.A.S.; Silveira, M.; Margonari, C.; Marcon, G.E.B.; França, A.O.; Souza, L.; Castro, L.S.; OscarBordignon, M.; Fischer, E.; et al. Leishmania $(V$.$) braziliensis Infecting Bats from Pantanal Wetland, Brazil: First Records for Platyrrhinus$ lineatus and Artibeus planirostris. Acta Trop. 2017, 172, 217-222. [CrossRef]

44. Castro, L.S.; Dorval, M.E.C.; Matheus, L.M.D.; Bednaski, A.V.; Facco, G.G.; Silveira, M.; Santos, C.F.; Gontijo, C.M.F.; Oliveira, A.P.G.; Ferreira, E.C. Leishmania Presence in Bats in Areas Endemic for Leishmaniasis in Central-West Brazil. Int. J. Parasitol. Parasit. Wildl. 2020, 11, 261-267. [CrossRef]

45. Gómez-Hernández, C.; Bento, E.C.; Rezende-Oliveira, K.; Nascentes, G.A.N.; Barbosa, C.G.; Batista, L.R.; Tiburcio, M.G.S.; Pedrosa, A.L.; Lages-Silva, E.; Ramírez, J.D.; et al. Leishmania Infection in Bats from a Non-Endemic Region of Leishmaniasis in Brazil. Parasitology 2017, 144, 1980-1985. [CrossRef]

46. Naiff, R.D.; Freitas, R.A.; Naiff, M.F.; Arias, J.R.; Barrett, T.V.; Momen, H.; Grimaldi Júnior, G. Epidemiological and Nosological aspects of Leishmania naiffi Lainson \& Shaw, 1989. Mem Inst. Oswaldo Cruz 1991, 86, 317-321. [PubMed]

47. Llanos-Cuentas, E.A.; Roncal, N.; Villaseca, P.; Paz, L.; Ogusuku, E.; Perez, J.E.; Cáceres, A.; Davies, C.R. Natural infections of Leishmania peruviana in animals in the Peruvian Andes. Trans. R. Soc. Trop. Med. Hyg. 1999, 93, 15-20. [CrossRef]

48. Quintal, A.P.; Ribeiro, E.S.; Rodrigues, F.P.; Rocha, F.S.; Floeter-Winter, L.M.; Nunes, C.M. Leishmania spp. in Didelphis albiventris and Micoureus paraguayanus (Didelphimorphia: Didelphidae) of Brazil. Vet. Parasitol. 2011, 176, 112-119. [CrossRef]

49. Ocampo, C.B.; Ferro, M.C.; Cadena, H.; Gongora, R.; Pérez, M.; Valderrama-Ardila, C.H.; Quinnell, R.J.; Alexander, N. Environmental Factors Associated with American Cutaneous Leishmaniasis in a New Andean Focus in Colombia. Trop. Med. Int. Health 2012, 17, 1309-1317. [CrossRef] [PubMed] 
50. de Castro Ferreira, E.; Cruz, I.; Cañavate, C.; de Melo, L.A.; Pereira, A.A.S.; Madeira, F.A.M.; Nogueira Valério, S.A.; Cunha, H.M.; Paglia, A.P.; Ferreira Gontijo, C.M. Mixed Infection of Leishmania infantum and Leishmania braziliensis in Rodents from Endemic Urban Area of the New World. BMC Vet. Res. 2015, 11, 1-7. [CrossRef]

51. Silva, E.M.; Alves, L.C.; Guerra, N.R.; Farias, M.P.; Oliveira, E.L.; de Souza, R.C.; da Cunha, C.; Ramos, R.A.; Porto, W.J. Leishmania spp. in Didelphis spp. from Northeastern Brazil. J. Zoo Wildl. Med. 2016, 47, 942-944. [CrossRef] [PubMed]

52. Paiz, L.; Donalisio, M.R.; Richini-Pereira, V.B.; Motoie, G.; Castagna, C.L.; Tolezano, J.E. Infection by Leishmania spp. in FreeRanging Opossums (Didelphis albiventris) in an Environmentally Protected Area Inhabited by Humans in Southeastern Brazil. Vector Borne Zoonotic Dis. 2016, 16, 728-730. [CrossRef] [PubMed]

53. Pereira, A.A.S.; De Castro Ferreira, E.; Da Rocha Lima, A.C.V.M.; Tonelli, G.B.; Rêgo, F.D.; Paglia, A.D.; Andrade-Filho, J.D.; Paz, G.F.; Gontijo, C.M.F. Detection of Leishmania spp in Silvatic Mammals and Isolation of Leishmania (Viannia) braziliensis from Rattus rattus in an Endemic Area for Leishmaniasis in Minas Gerais State, Brazil. PLoS ONE 2017, 12, e0187704. [CrossRef]

54. Donalisio, M.R.; Paiz, L.M.; da Silva, V.G.; Richini-Pereira, V.B.; von Zuben, A.P.B.; Castagna, C.L.; Motoie, G.; Hiramoto, R.M.; Tolezano, J.E. Visceral leishmaniasis in an environmentally protected area in southeastern Brazil: Epidemiological and laboratory cross-sectional investigation of phlebotomine fauna, wild hosts and canine cases. PLoS Negl. Trop. Dis. 2017, 11, e0005666. [CrossRef]

55. Brandão, E.; Xavier, S.C.; Rocha, F.L.; Lima, C.F.; Candeias, Í.Z.; Lemos, F.G.; Azevedo, F.C.; Jansen, A.M.; Roque, A.L. Trypanosomatids in Small Mammals of an Agroecosystem in Central Brazil: Another Piece in the Puzzle of Parasite Transmission in an Anthropogenic Landscape. Pathogens 2019, 8, 190. [CrossRef]

56. González, K.; Calzada, J.E.; Saldaña, A.; Rigg, C.A.; Alvarado, G.; Rodríguez-Herrera, B.; Kitron, U.D.; Adler, G.H.; Gottdenker, N.L.; Chaves, L.F.; et al. Survey of Wild Mammal Hosts of Cutaneous Leishmaniasis Parasites in Panamá and Costa Rica. Trop. Med. Health 2015, 43, 75-78. [CrossRef]

57. Silveira, F.T.; Lainson, R.; Shaw, J.J.; Braga, R.R.; Ishikawa, E.E.; Souza, A.A. Cutaneous leishmaniasis in Amazonia: Isolation of Leishmania (Viannia) lainsoni from the rodent Agouti paca (Rodentia: Dasyproctidae), in the state of Para, Brazil. Rev. Inst. Med. Trop. Sao Paulo 1991, 33, 18-22. [CrossRef]

58. Oliveira, F.S.; Pirmez, C.; Pires, M.Q.; Brazil, R.P.; Pacheco, R.S. PCR-Based Diagnosis for Detection of Leishmania in Skin and Blood of Rodents from an Endemic Area of Cutaneous and Visceral Leishmaniasis in Brazil. Vet. Parasitol. 2005, 129, $219-227$. [CrossRef]

59. de Freitas, T.P.; D'Andrea, P.S.; de Paula, D.A.; Nakazato, L.; Dutra, V.; Bonvicino, C.R.; de Almeida, A.d.B.P.F.; Boa-Sorte, E.d.; Sousa, V.R.F. Natural infection of Leishmania (Viannia) braziliensis in Mus musculus captured in Mato Grosso, Brazil. Vector Borne Zoonotic Dis. 2012, 12, 81-83. [CrossRef]

60. Brito, M.E.F.; Andrade, M.S.; Mendonça, M.G.; Silva, C.J.; Almeida, E.L.; Lima, B.S.; Félix, S.M.; Abath, F.G.C.; da Graça, G.C.; Porrozzi, R.; et al. Species Diversity of Leishmania (Viannia) Parasites Circulating in an Endemic Area for Cutaneous Leishmaniasis Located in the Atlantic Rainforest Region of Northeastern Brazil. Trop. Med. Int. Health 2009, 14, 1278-1786. [CrossRef]

61. De Bruijn, M.H.L.; Barker, D.C. Diagnosis of New World leishmaniasis: Specific detection of species of the Leishmania braziliensis complex by amplification of kinetoplast DNA. Acta Trop. 1992, 52, 45-58. [CrossRef]

62. Marcelino, A.P.; Ferreira, E.C.; Avendanha, J.S.; Costa, C.F.; Chiarelli, D.; Almeida, G.; Moreira, E.C.; Leite, R.C.; dos Reis, J.K.P.; Gontijo, C.M.F. Molecular Detection of Leishmania braziliensis in Rattus norvegicus in an Area Endemic for Cutaneous Leishmaniasis in Brazil. Vet. Parasitol. 2011, 183, 54-58. [CrossRef]

63. Vasconcelos, I.A.; Vasconcelos, A.W.; Fe Filho, N.M.; Queiroz, R.G.; Santana, E.W.; Bozza, M.; Sallenave, S.M.; Valim, C.; David, J.R.; Lopes, U.G. The identity of Leishmania isolated from sand flies and vertebrate hosts in a major focus of cutaneous leishmaniasis in Baturité, northeastern Brazil. Am. J. Trop Med. Hyg. 1994, 50, 158-164. [CrossRef]

64. Martínez, M.F.; Kowalewski, M.M.; Giuliani, M.G.; Acardi, S.A.; Salomón, O.D. Molecular Identification of Leishmania in Free-Ranging Black and Gold Howler Monkeys (Alouatta caraya) in Northeastern Argentina. Acta Trop. 2020, $210,105534$. [CrossRef]

65. Acardi, S.A.; Rago, M.V.; Liotta, D.J.; Fernandez-Duque, E.; Salomón, O.D. Leishmania (Viannia) DNA Detection by PCR-RFLP and Sequencing in Free-Ranging Owl Monkeys (Aotus azarai azarai) from Formosa, Argentina. Vet. Parasitol. 2013, 193, 256-259. [CrossRef]

66. Savani, E.S.; de Almeida, M.F.; de Oliveira Camargo, M.C.; D'Auria, S.R.; Silva, M.M.; de Oliveira, M.L.; Sacramento, D. Detection of Leishmania (Leishmania) amazonensis and Leishmania (Leishmania) infantum chagasi in Brazilian bats. Vet. Parasitol. 2010, 168, 5-10. [CrossRef] [PubMed]

67. De Lima, V.M.F.; Santiago, M.E.B.; Sanches, L.dC.; de Lima, B.D. Molecular diagnosis of Leishmania amazonensis ina captive spider monkey in Bauru, Sao Paulo, Brazil. J. Zoo Wildl. Med. 2012, 43, 943-945. [CrossRef]

68. Kerr, S.F.; Emmons, L.H.; Melby, P.C.; Liu, C.; Perez, L.E.; Villegas, M.; Miranda, R. Leishmania amazonensis infections in Oryzomys acritus and Oryzomys nitidus from Bolivia. Am. J. Trop. Med. Hyg. 2006, 75, 1069-1073. [CrossRef] [PubMed]

69. Zamora-Ledesma, S.; Hernández-Camacho, N.; Villagrán-Herrera, M.E.; Sánchez-Moreno, M.; Concha-Valdez, F.G.; Jones, R.W.; Moreno-Pérez, M.A.; Camacho-Macías, B. Presence of Trypanosomatid Antibodies in Gray Foxes (Urocyon cinereoargenteus) and Domestic and Feral Dogs (Canis lupus familiaris). Vet. Parasitol. Reg. Stud. Rep. 2016, 5, 25-30. [CrossRef] [PubMed] 
70. Berzunza-Cruz, M.; Rodríguez-Moreno, A.; Gutiérrez-Granados, G.; González-Salazar, C.; Stephens, C.R.; Hidalgo-Mihart, M.; Marina, C.F.; Rebollar-Téllez, E.A.; Bailón-Martínez, D.; Balcells, C.D.; et al. Leishmania (L.) mexicana Infected Bats in Mexico: Novel Potential Reservoirs. PLoS Negl. Trop. Dis. 2015, 9, e0003438. [CrossRef] [PubMed]

71. Van Wynsberghe, N.R.; Canto-Lara, S.B.; Sosa-Bibiano, E.I.; Rivero-Cardenas, N.A.; Andrade-Narvaez, F.J. Comparison of small mammal prevalence of Leishmania (Leishmania) mexicana in five foci of cutaneous leishmaniasis in the State State of Campeche, Mexico. Rev. Inst. Med. Trop. Sao Paulo 2009, 51, 87-94. [CrossRef] [PubMed]

72. Van Wynsberghe, N.R.; Canto-Lara, S.B.; Mian-Centeno, A.G.; Itza-Ortiz, M.F.; Andrade-Narvaez, F.J. Retention of Leishmania (Leishmania) mexicana in naturally infected rodents from the State of Campeche, Mexico. Mem. Inst. Oswaldo Cruz 2000, 95, 595-600. [CrossRef]

73. Kerr, S.F.; McHugh, C.P.; Dronen, N.O., Jr. Leishmaniasis in Texas: Prevalence and seasonal transmission of Leishmania mexicana in Neotoma micropus. Am. J. Trop. Med. Hyg. 1995, 53, 73-77. [CrossRef]

74. Raymond, R.W.; McHugh, C.P.; Witt, L.R.; Kerr, S.F. Temporal and Spatial Distribution of Leishmania mexicana Infections in a Population of Neotoma micropus. Mem. Inst. Oswaldo Cruz 2003, 98, 171-180. [CrossRef]

75. Canto-Lara, S.B.; Van Wynsberghe, N.R.; Vargas-González, A.; Ojeda-Farfán, F.F.; Andrade-Narváez, F.J. Use of Monoclonal Antibodies for the Identification of Leishmania Spp. Isolated from Humans and Wild Rodents in the State of Campeche, Mexico. Mem. Inst. Oswaldo Cruz 1999, 94, 305-309. [CrossRef]

76. McHug, C.P.; Thies, M.L.; Melby, P.C.; Yantis, L.D.; Raymond, R.W.; Villegas, M.D.; Kerr, S.F. Short report: A disseminated infection of Leishmania mexicana in an eastern woodrat, Neotoma floridana, collected in Texas. Am. J. Trop. Med. Hyg. 2003, 69, 470-472. [CrossRef]

77. Chable-Santos, J.B.; Van Wynsberghe, N.R.; Canto-Lara, S.B.; Andrade-Narvaez, F.J. Isolation of Leishmania (L.) mexicana from Wild Rodents and Their Possible Role in the Transmission of Localized Cutaneous Leishmaniasis in the State of Campeche, Mexico. Am. J. Trop. Med. Hyg. 1995, 53, 141-145. [CrossRef]

78. Kipp, E.J.; Mariscal, J.; Armijos, R.X.; Weigel, M.; Waldrup, K. Genetic Evidence of Enzootic Leishmaniasis in a Stray Canine and Texas Mouse from Sites in West and Central Texas. Mem. Inst. Oswaldo Cruz 2016, 111, 652-654. [CrossRef]

79. Muñoz-García, C.I.; Sánchez-Montes, S.; Villanueva-García, C.; Romero-Callejas, E.; Díaz-López, H.M.; Gordillo-Chávez, E.J.; Martínez-Carrasco, C.; Berriatua, E.; Rendón-Franco, E. The Role of Sloths and Anteaters as Leishmania Spp. Reservoirs: A Review and a Newly Described Natural Infection of Leishmania mexicana in the Northern Anteater. Parasitol. Res. 2019, 118, 1095-1101. [CrossRef]

80. Rovirosa-Hernández, M.J.; Cortes-Ortíz, L.; García-Orduña, F.; Guzmán-Gómez, D.; López-Monteon, A.; Caba, M.; RamosLigonio, A. Seroprevalence of Trypanosoma cruzi and Leishmania mexicana in free-ranging howler monkeys in southeastern Mexico. Am. J. Primatol. 2013, 75, 161-169. [CrossRef]

81. Courtenay, O.; Quinnell, R.J.; Garcez, L.M.; Dye, C. Low Infectiousness of a Wildlife Host of Leishmania Infantum: The Crab-Eating Fox Is Not Important for Transmission. Parasitology 2002, 125, 407-414. [CrossRef]

82. de Almeida Curi, N.H.; Miranda, I.; Talamoni, S.A. Serologic Evidence of Leishmania Infection in Free-Ranging Wild and Domestic Canids around a Brazilian National Park. Mem. Inst. Oswaldo Cruz 2006, 101, 99-101. [CrossRef]

83. Gomes, R.B.; Mendonca, I.L.; Silva, V.C.; Ruas, J.; Silva, M.B.; Cruz, M.S.P.; Barral, A.; Costa, C.H.N. Antibodies against Lutzomya longipalpis saliva in the fox Cerdocyon thous and the sylvatic cycle of Leishmania chagasi. Trans. R. Soc. Trop. Med. Hyg. 2007, 101, 127-133. [CrossRef]

84. Luppi, M.M.; Malta, M.C.C.; Silva, T.M.A.; Silva, F.L.; Motta, R.O.C.; Miranda, I.; Ecco, R.; Santos, R.L. Visceral Leishmaniasis in Captive Wild Canids in Brazil. Vet. Parasitol. 2008, 155, 146-151. [CrossRef]

85. Jusi, M.M.G.; Starke-Buzetti, W.A.; de Sousa Oliveira, T.M.F.; da Silva Tenório, M.; de Oliveira de Sousa, L.; Zacarias Machad, R. Molecular and Serological Detection of Leishmania spp. in Captive Wild Animals from Ilha Solteira, SP, Brazil. Rev. Bras. de Parasitol. Veterinária 2011, 20, 219-222. [CrossRef]

86. Richini-Pereira, V.B.; Marson, P.M.; Hayasaka, E.Y.; Victoria, C.; da Silva, R.C.; Langoni, H. Molecular Detection of Leishmania Spp. in Road-Killed Wild Mammals in the Central Western Area of the State of São Paulo, Brazil. J. Ven. Anim. Tox. Trop. Dis. 2014, 20, 27. [CrossRef] [PubMed]

87. Almeida, J.C.; Melo, R.P.B.; Kim, P.C.P.; Guerra, N.R.; Alves, L.C.; Costa, D.F.; Alves, C.J.; Porto, W.J.N.; Mota, R.A. Molecular and Serological Investigation of Infectious Diseases in Captive and Free-Range Crab-Eating Fox (Cerdocyon thous-Linnaeus, 1776) from Northeastern Brazil. Acta Parasitol. 2018, 63, 184-189. [CrossRef] [PubMed]

88. de Almeida Curi, N.H.; Coelho, C.M.; Malta, M.C.C.; Magni, L.M.V.; Sábato, M.A.L.; Araújo, A.S.; Lobato, Z.I.P.; Santos, J.L.C.; Santos, H.A.; Ragozo, A.A.M.; et al. Pathogens of Wild Maned Wolves (Chrysocyon brachyurus) in Brazil. J. Wildl. Dis. 2012, 48, 1052-1056. [CrossRef] [PubMed]

89. Mol, J.P.S.; Soave, S.A.; Turchetti, A.P.; Pinheiro, G.R.G.; Pessanha, A.T.; Malta, M.C.C.; Tinoco, H.P.; Figueiredo, L.A.; Gontijo, N.F.; Paixão, T.A.; et al. Transmissibility of Leishmania infantum from Maned Wolves (Chrysocyon brachyurus) and Bush Dogs (Speothos venaticus) to Lutzomyia longipalpis. Vet. Parasitol. 2015, 212, 86-91. [CrossRef]

90. Tolentino, N.; Pinheiro, G.R.G.; Ottino, J.; Rodrigues de Oliveira, A.; Coelho, C.M.; Tinoco, H.P.; Fujiwara, R.T.; Santos, R.L.; Ribeiro, V.M. Serological Evidence of Leishmania Infection by Employing ELISA and Rapid Tests in Captive Felids and Canids in Brazil. Vet. Parasitol. Reg. Stud. Rep. 2019, 17, 100308. [CrossRef] 
91. Lombardi, M.C.; Turchetti, A.P.; Tinoco, H.P.; Pessanha, A.T.; Soave, S.A.; Malta, M.C.C.; Paixão, T.A.; Santos, R.L. Diagnosis of Leishmania Infantum Infection by Polymerase Chain Reaction in Wild Mammals. Pesquisa Vet. Brasil. 2014, 34, 1243-1246. [CrossRef]

92. Paiz, L.M.; Fornazari, F.; Menozzi, B. Serological Evidence of Infection by Leishmania (Leishmania) infantum (Synonym: Leishmania (Leishmania) chagasi) in Free-Ranging Wild Mammals in a Nonendemic Region of the State of São Paulo, Brazil. Vector Borne Zoonotic Dis. 2015, 11, 667-673. [CrossRef]

93. Dahroug, M.A.; Almeida, A.B.; Sousa, V.R.; Dutra, V.; Turbino, N.C.; Nakazato, L.; de Souza, R.L. Leishmania (Leishmania) chagasi in captive wild felids in Brazil. Trans. R. Soc. Trop. Med. Hyg. 2010, 104, 73-74. [CrossRef]

94. Dahroug, M.A.; Almeida, A.B.; Sousa, V.R.; Dutra, V.; Guimarães, L.D.; Soares, C.E.; Nakazato, L.; de Souza, R.L. The first case report of Leishmania (leishmania) chagasi in Panthera leo in Brazil. Asian Pac. J. Trop. Biomed. 2011, 3, 249-250. [CrossRef]

95. de Rezende, M.B.; Herrera, H.M.; Carvalho, C.M.E.; Carvalho Anjos, E.A.; Ramos, C.A.N.; de Araújo, F.R.; Torres, J.M.; de Oliveira, C.E. Detection of Leishmania spp. in Bats from an Area of Brazil Endemic for Visceral Leishmaniasis. Trans. Emerg. Dis. 2017, 64, e36-e42. [CrossRef]

96. Medkour, H.; Davoust, B.; Dulieu, F.; Maurizi, L.; Lamour, T.; Marié, J.L.; Mediannikov, O. Potential animal reservoirs (dogs and bats) of human visceral leishmaniasis due to Leishmania infantum in French Guiana. PLoS Negl. Trop. Dis. 2019, 13, e0007456. [CrossRef]

97. De Lima, H.; Rodriguez, N.; Barrios, M.A.; Avila, A.; Canizales, I.; Gutierrez, S. Isolation and molecular identification of Leishmania chagasi from a bat (Carollia perspicillata) in northeastern Venezuela. Mem. Inst. Oswaldo Cruz 2008, 103, 412-414. [CrossRef]

98. Pereira da Costa, A.; Costa, F.B.; Soares, H.S.; Ramirez, D.G.; de Carvalho, E.T.K.; Gennari, S.M.; Marcili, A. Trypanosoma cruzi and Leishmania infantum chagasi Infection in Wild Mammals from Maranhão State, Brazil. Vector Borne Zoonotic Dis. 2015, 15, 656-666. [CrossRef]

99. de Araujo, V.A.; Boite, M.C.; Cupolillo, E.; Jansen, A.M.; Roque, A.L. Mixed infection in the anteater Tamandua tetradactyla (Mammalia: Pilosa) from Para State, Brazil: Trypanosoma cruzi, T. rangeli and Leishmania infantum. Parasitology 2013, 140, 455-460. [CrossRef]

100. Humberg, R.M.; Oshiro, E.T.; Cruz, M.S.; Ribolla, P.E.; Alonso, D.P.; Ferreira, A.M.; Bonamigo, R.A.; Tasso, N., Jr.; de Oliveira, A.G. Leishmania chagasi in opossums (Didelphis albiventris) in an urban area endemic for visceral leishmaniasis, Campo Grande, Mato Grosso do Sul, Brazil. Am. J. Trop. Med. Hyg. 2012, 87, 470-472. [CrossRef]

101. Santiago, M.E.; Vasconcelos, R.O.; Fattori, K.R.; Munari, D.P.; Michelin, A.F.; Lima, V.M. An investigation of Leishmania spp. in Didelphis spp. from urban and peri-urban areas in Bauru (Sao Paulo, Brazil). Vet. Parasitol. 2007, 150, 283-290. [CrossRef]

102. Carreira, J.C.; da Silva, A.V.; de Pita, P.D.; Brazil, R.P. Natural infection of Didelphis aurita (Mammalia: Marsupialia) with Leishmania infantum in Brazil. Parasit. Vectors 2012, 5, 111. [CrossRef]

103. Viettri, M.; Herrera, L.; Aguilar, C.M.; Morocoima, S.; Reyes, J.; Lares, M.; Lozano-Arias, D.; García-Alzate, R.; Chacón, T.; Feliciangeli, M.D.; et al. Molecular Diagnosis of Trypanosoma cruzi/Leishmania Spp. Coinfection in Domestic, Peridomestic and Wild Mammals of Venezuelan Co-Endemic Areas. Vet. Parasitol. Reg. Stud. Rep. 2018, 14, 123-130. [CrossRef]

104. Corredor, A.; Gallego, J.F.; Tesh, R.B.; Pelaez, D.; Diaz, A.; Montilla, M.; Palau, M.T. Didelphis marsupialis, an apparent wild reservoir of Leishmania donovani chagasi in Colombia, South America. Trans. R. Soc. Trop. Med. Hyg. 1989, 83, 195. [CrossRef]

105. Travi, B.L.; Jaramillo, C.; Montoya, J.; Segura, I.; Zea, A.; Goncalves, A.; Velez, I.D. Didelphis marsupialis, an important reservoir of Trypanosoma (Schizotrypanum) cruzi and Leishmania (Leishmania) chagasi in Colombia. Am. J. Trop. Med. Hyg. 1994, 50, 557-565. [CrossRef]

106. Travi, B.L.; Osorio, Y.; Becerra, M.T.; Adler, G.H. Dynamics of Leishmania chagasi infection in small mammals of the undisturbed and degraded tropical dry forests of northern Colombia. Trans. R. Soc. Trop. Med. Hyg. 1998, 92, 275-278. [CrossRef]

107. Zulueta, A.M.; Villarroel, E.; Rodriguez, N.; Feliciangeli, M.D.; Mazzarri, M.; Reyes, O.; Rodriguez, V.; Centeno, M.; Barrios, R.M.; Ulrich, M. Epidemiologic Aspects of American Visceral Leishmaniasis in an Endemic Focus in Eastern Venezuela. Am. J. Trop. Med. Hyg. 1999, 61, 945-950. [CrossRef]

108. Malta, M.C.; Tinoco, H.P.; Xavier, M.N.; Vieira, A.L.; Costa, E.A.; Santos, R.L. Naturally acquired visceral leishmaniasis in non-human primates in Brazil. Vet. Parasitol. 2010, 169, 193-197. [CrossRef] [PubMed]

109. Paiz, L.M.; Motoie, G.; Richini-Pereira, V.B.; Langoni, H.; Menozzi, B.D.; Tolezano, J.E.; Donalisio, M.R. Antibodies and molecular detection of Leishmania (Leishmania) infantum in samples of free-ranging marmosets (Primates: Callicitrichidae: Callithrix spp.) in an area of canine visceral leishmaniasis in southeastern Brazil. Vector Borne Zoonotic Dis. 2019, 19, 249-254. [CrossRef] [PubMed]

110. Moreno, E.S.; Sabioni, L.A.; Moraes de Seixas, M.M.; de Souza Filho, J.A.; Marcelino, A.P. Paloma Helena Fernandes Shimabukuro. Evidence of a Sylvatic Enzootic Cycle of Leishmania infantum in the State of Amapá, Brazil. Rev. Da Soc. Brasil. Med. Trop. 2020, 53, 13-15. [CrossRef]

111. Rosypal, A.C.; Tripp, S.; Lewis, S.; Francis, J.; Stoskopf, M.K.; Larsen, R.S.; Lindsay, D. Survey of antibodies to Trypanosoma cruzi and Leishmania spp. in gray and red fox populations from North Carolina and Virginia. J. Parasitol. 2010, 96, $1230-1231$. [CrossRef] [PubMed]

112. Rosypal, A.C.; Alexander, A.; Byrd, D.; Weaver, M.; Stewart, R.; Gerhold, R.; Houston, A.; vanWhy, K.; Dubey, J.P. Survey of antibodies to Leishmania spp. in wild canids from Pennsylvania and Tennesee. J. Zoo Wildl. Med. 2013, 44, 1131-1133. [CrossRef] 
113. Millán, J.; Travaini, A.; Zanet, S.; López-Bao, J.V.; Trisciuoglio, A.; Ferroglio, E.; Rodríguez, A. Detection of Leishmania DNA in Wild Foxes and Associated Ticks in Patagonia, Argentina, $2000 \mathrm{Km}$ South of Its Known Distribution Area. Parasit. Vectors 2016, 9, 241. [CrossRef]

114. Reis, F.; Minuzzi-Souza Mariana, T.T.C.; Renata, N.; De Morais, I.O.B.; De Lima, T.M.; Hecht, M.; Nitz, N.; Gurgel-Gonçalves, R. Trypanosomatid Infections in Captive Wild Mammals and Potential Vectors at the Brasilia Zoo, Federal District, Brazil. Vet. Med. Sci. 2020, 6, 248-256. [CrossRef]

115. Brandao, E.M.V.; Xavier, S.C.C.; Rocha, F.L.; Lima, C.F.M.; Roque, A.L.R. Wild and Domestic Canids and Their Interactions in the Transmission Cycles of Trypanosoma cruzi and Leishmania spp. in an Area of the Brazilian Cerrado. Pathogens 2020, 9, 818. [CrossRef]

116. Porfirio, F.E.O.; Santos, F.M.; Carvalho de Macedo, G.; Barreto, W.T.G.; Campos, J.B.V.; Meyers, A.C.; André, M.R.; Perles, L.; Oliveira, C.E.; ChagasXavier, S.C.D.; et al. Maintenance of Trypanosoma cruzi, T. evansi and Leishmania spp. by Domestic Dogs and Wild Mammals in a Rural Settlement in Brazil-Bolivian Border. Int. J. Parasitol. Parasit. Wildl. 2018, 7, 398-404. [CrossRef]

117. Lima, V.M.F.; Fattori, F.R.; Apargecida de Fátima Michelin, A.F.; Nogueira, F.S.; de Oliveira e Souza, L. Evidence of Leishmania spp. Antibodies and DNA in Bush Dogs (Speothos venaticus) in Brazil. J. Zoo Wildl. Med. 2009, 40, 91-94. [CrossRef]

118. Johnson, R.N.; Young, D.G.; Butler, J.F.; Bogaert-Diaz, H. Possible Determination of the Vector and Reservoir of Leishmaniasis in the Dominican Republic. Am. J. Trop. Med. Hyg. 1992, 46, 282-287. [CrossRef]

119. Medkour, H.; Davoust, B.; Levasseur, A.; Mediannikov, O. Molecular Evidence of Leishmania infantum and Leishmania guyanensis in Red Howler Monkey (Alouatta seniculus) from French Guiana. Vector Borne Zoonotic Dis. 2019, 12, 896-900. [CrossRef]

120. Babuadze, G.; Alvar, J.; Argaw, D.; de Koning, H.P.; Iosava, M.; Kekelidze, M.; Tsertsvadze, N.; Tsereteli, D.; Chakhunashvili, G.; Mamatsashvili, T.; et al. Epidemiology of Visceral Leishmaniasis in Georgia. PLoS Negl. Trop. Dis. 2014, 8, e2725. [CrossRef]

121. Mitková, B.; Hrazdilová, K.; Amico, G.D.; Duscher, G.G.; Suchentrunk, F.; Forejtek, P.; Gherman, M.; Matei, I.A.; Ionică, A.M.; Daskalaki, A.A.; et al. Eurasian Golden Jackal as Host of Canine Vector-Borne Protists. Parasit. Vectors 2017, 10, 183. [CrossRef]

122. Mohebali, M.; Arzamani, K.; Zarei, Z.; Akhoundi, B.; Hajjaran, H.; Raeghi, S.; Heidari, Z.; Motavalli-Haghi, S.M.; Elikaee, S.; Mousazadeh-Mojarrad, A.; et al. Canine Visceral Leishmaniasis in Wild Canines (Fox, Jackal and Wolf) in Northeastern Iran Using Parasitological, Serological, and Molecular Methods. J. Arthopod Borne Dis. 2016, 10, 538-545.

123. Talmi-Frank, D.; Kedem-Vaanunu, N.; King, R.; Bar-Gal, G.K.; Edery, N.; Jaffe, C.L.; Baneth, G. Leishmania tropica Infection in Golden Jackals and Red Foxes, Israel. Emerg. Infect. Dis. 2010, 16, 1973-1975. [CrossRef]

124. Beck, A.; Beck, R.; Kusak, J.; Gudan, A.; Martinkovic, F.; Artukovic, B.; Hohšteter, M.; Huber, D.; Marinculic, A.; Grabarevic, Z. A Case of Visceral Leishmaniosis in a Gray Wolf (Canis lupus) from Croatia. J. Wildl. Dis. 2008, 44, 451-456. [CrossRef]

125. Sobrino, R.; Ferroglio, E.; Oleaga, A.; Romano, A.; Millan, J.; Revilla, M.; Arnal, M.C.; Trisciuoglio, A.; Gortázar, C. Characterization of Widespread Canine Leishmaniasis among Wild Carnivores from Spain. Vet. Parasitol. 2008, 155, 198-203. [CrossRef]

126. Oleaga, A.; Vicente, J.; Ferroglio, E.; Pegoraro de Macedo, M.R.; Casais, R.; Del Cerro, A.; Espí, A.; García, E.J.; Gortázar, C. Concomitance and Interactions of Pathogens in the Iberian Wolf (Canis lupus). Res. Vet. Sci. 2015, 101, 22-27. [CrossRef]

127. Oleaga, A.; Zanet, S.; Espí, A.; Raquel, M.; De Macedo, P.; Gortázar, C.; Ferroglio, E. Leishmania in Wolves in Northern Spain: A Spreading Zoonosis Evidenced by Wildlife Sanitary Surveillance. Vet. Parasitol. 2018, 255, 26-31. [CrossRef] [PubMed]

128. Risueño, J.; Ortuño, M.; Pérez-Cutillas, P.; Goyena, E.; Maia, C.; Cortes, S.; Campino, L.; BernalL, J.; Muñoz, C.; ArcenillasI, L.; et al. Epidemiological and Genetic Studies Suggest a Common Leishmania infantum Transmission Cycle in Wildlife, Dogs and Humans Associated to Vector Abundance in Southeast Spain. Vet. Parasitol. 2018, 259, 61-67. [CrossRef] [PubMed]

129. Ortuño, M.; Latrofa, M.S.; Iborra, M.A.; Pérez, P.; Bernal, L.J.; Risueño, J.; Muñoz, C.; Bernal, A.; Sánchez-Lopez, P.F.; Segovia, M.; et al. Genetic Diversity and Phylogenetic Relationships between Leishmania infantum from Dogs, Humans and Wildlife in South East Spain. Zoonoses Public Health 2019, 66, 961-973. [CrossRef] [PubMed]

130. Sastre, N.; Francino, O.; Ramírez, O.; Enseñat, C.; Sánchez, A.; Altet, L. Detection of Leishmania infantum in Captive Wolves from Southwestern Europe. Vet. Parasitol. 2008, 158, 117-120. [CrossRef] [PubMed]

131. Muñoz-Madrid, R.; Belinchón-Lorenzo, S.; Iniesta, V.; Fernández-Cotrina, J.; Parejo, J.C.; Serrano, F.J.; Monroy, I.; Baz, V.; GómezLuque, A.; Gómez-Nieto, L.C. First Detection of Leishmania infantum Kinetoplast DNA in Hair of Wild Mammals: Application of QPCR Method to Determine Potential Parasite Reservoirs. Acta Trop. 2013, 128, 706-709. [CrossRef] [PubMed]

132. Battisti, E.; Zanet, S.; Khalili, S.; Trisciuoglio, A.; Hertel, B.; Ferroglio, E. Molecular Survey on Vector-Borne Pathogens in Alpine Wild Carnivorans. Front. Vet. Sci. 2020, 7, 1-9. [CrossRef]

133. Del Río, L.; Chitimia, L.; Cubas, A.; Victoriano, I.; De la Rúa, P.; Gerrikagoitia, X.; Barral, M.; Muñoz-García, C.I.; Goyena, E.; García-Martínez, D.; et al. Evidence for Widespread Leishmania infantum Infection among Wild Carnivores in L. infantum Periendemic Northern Spain. Prev. Vet. Med. 2014, 113, 430-435. [CrossRef]

134. Millán, J.; Zanet, S.; Gomis, M.; Trisciuoglio, A.; Negre, N.; Ferroglio, E. An Investigation into Alternative Reservoirs of Canine Leishmaniasis on the Endemic Island of Mallorca (Spain). Trans. Emerg. Dis. 2011, 58, 352-357. [CrossRef]

135. Gomes, J.; Rocha, H.; Carvalho, C.; Bandeira, V.; Fonseca, C.; Rosalino, L.M.; Cunha, M.V. Molecular Detection and Characterization of Leishmania infantum in Free-Ranging Egyptian Mongoose (Herpestes ichneumon). Int. J. Parasitol. Parasit. Wildl. 2020, 11, 158-162. [CrossRef]

136. Tsakmakidis, G.; Pavlou, C.; Tamvakis, A.; Papadopoulos, T.; Christodoulou, V.; Angelopoulou, K.; Dovas, C.; Antoniou, M.; Anastasakis, C.; Diakou, A. Leishmania infection in lagomorphs and minks in Greece. Vet. Parasitol. Reg. Stud. Rep. 2019, 16, 100279. [CrossRef] 
137. Alcover, M.M.; Ribas, A.; Guillén, M.C.; Berenguer, D.; Tomás-Pérez, M.; Riera, C.; Fisa, R. Wild Mammals as Potential Silent Reservoirs of Leishmania infantum in a Mediterranean Area. Prev. Vet. Med. 2020, 175, 104874. [CrossRef]

138. Calavera, M.A.; Latta, R.; Laricchiuta, P.; Passantino, G.; Abramo, F.; Mendoza-Roldan, J.A.; Otranto, D.; Zatelli, A. Clinical, haematological and biochemical findings in tigers infected by Leishmania infantum. BMC Vet. Res. 2020, 16, 214. [CrossRef]

139. Mancianti, F.; Mignone, W.; Galastri, F. Serologic Survey for Leishmaniasis in Free-Living Red Foxes (Vulpes vulpes) in Italy. J. Wildl. Dis. 1994, 30, 454-456. [CrossRef]

140. Criado-Fornelio, A.; Gutierrez-Garcia, L.; Rodriguez-Caabeiro, F.; Reus-Garcia, E.; Roldan-Soriano, M.A.; Diaz-Sanchez, M.A. A Parasitological Survey of Wild Red Foxes (Vulpes vulpes) from the Province of Guadalajara, Spain. Vet. Parasitol. 2000, 92, $245-251$. [CrossRef]

141. Dipineto, L.; Manna, L.; Baiano, A.; Gala, M.; Fioretti, A.; Gravino, A.E.; Menna, L.F. Presence of Leishmania infantum in Red Foxes (Vulpes vulpes) in Southern Italy. J. Wildl. Dis. 2007, 43, 518-520. [CrossRef]

142. Davoust, B.; Mary, C.; Marié, J.L. Detection of Leishmania in Red Foxes (Vulpes vulpes) from Southeastern France Using Real-Time Quantitative PCR. J. Wildl. Dis. 2014, 50, 130-132. [CrossRef]

143. Karayiannis, S.; Ntais, P.; Messaritakis, I.; Tsirigotakis, N.; Dokianakis, E.; Antoniou, M. Detection of Leishmania infantum in Red Foxes (Vulpes vulpes) in Central Greece. Parasitology 2015, 142, 1574-1578. [CrossRef]

144. Lledó, L.; Giménez-Pardo, C.; Saz, J.V.; Serrano, J.L. Wild Red Foxes (Vulpes vulpes) as Sentinels of Parasitic Diseases in the Province of Soria, Northern Spain. Vector Borne Zoonotic Dis. 2015, 15, 743-749. [CrossRef]

145. Abbate, L.M.; Arfuso, F.; Napoli, E.; Gaglio, G.; Giannetto, S.; Latrofa, M.S.; Otranto, D.; Brianti, E. Leishmania infantum in Wild Animals in Endemic Areas of Southern Italy. Comp. Immunol. Microbiol. Infect. Dis. 2019, 67, 101374. [CrossRef]

146. Medkour, H.; Laidoudi, Y.; Marié, J.L.; Fenollar, F.; Davoust, B.; Mediannikov, O. Molecular Investigation of Vector-Borne Pathogens in Red Foxes (Vulpes vulpes) from Southern France. J. Wildl. Dis. 2020, 56, 837-850. [CrossRef]

147. Montoya, A.; Pérez De Quadros, L.; Mateo, M.; Hernández, L.; Gálvez, R.; Alcántara, G.; Checa, R.; Jiménez, M.Á.; Chicharro, C.; Israel Cruz, G.M. Leishmania infantum infection in Bennett's wallabies (Macropus rufogriseus rufogriseus) in a spanish wildlife park. J. Zoo Wildl. Med. 2016, 47, 586-593. [CrossRef]

148. Miró, G.; Troyano, A.; Montoya, A.; Fariñas, F.; Fermín, M.L.; Flores, L.; Rojo, C.; Checa, R.; Gálvez, R.; Marino, V.; et al. First report of L. infantum infection in the endangered orangutan (Pongo pygmaeus pygmaeus) in Madrid, Spain. Parasit. Vectors 2018, 11, 1-7. [CrossRef] [PubMed]

149. Azami-Conesa, I.; Martínez-Díaz, R.A.; González, F.; Gómez-Muñoz, M.T. First Detection of Leishmania infantum in Common Urban Bats Pipistrellus pipistrellus in Europe. Res. Vet. Sci. 2020, 132, 172-176. [CrossRef] [PubMed]

150. Chemkhi, J.; Souguir, H.; BelHadjAli, I.; Driss, M.; Guizani, I.; Guerbouj, S. Natural Infection of Algerian Hedgehog, Atelerix algirus (Lereboullet 1842) with Leishmania Parasites in Tunisia. Acta Trop. 2015, 150, 42-51. [CrossRef]

151. Souguir-Omrani, H.; Chemkhi, J.; Fathallah-Mili, A.; Saadi-BenAoun, Y.; BelHadjAli, I.; Guizani, I.; Guerbouj, S. Paraechinus aethiopicus (Ehrenberg 1832) and Atelerix algirus (Lereboullet 1842) Hedgehogs: Possible Reservoirs of Endemic Leishmaniases in Tunisia. Infect. Genet. Evol. 2018, 63, 219-230. [CrossRef] [PubMed]

152. Ruiz- Fons, F.; Ferroglio, E.; Gortázar, C. Leishmania infantum in Free-Ranging Hares, Spain, 2004-2010. Eurosurveillance 2013, 30, 80-81. [CrossRef] [PubMed]

153. Ortega, M.V.; Moreno, I.; Domínguez, M.; de la Cruz, M.L.; Martín, A.B.; Rodríguez-Bertos, A.; López, R.; Navarro, A.; González, S.; Mazariegos, M.; et al. Application of a Specific Quantitative Real-Time PCR (QPCR) to Identify Leishmania infantum DNA in Spleen, Skin and Hair Samples of Wild Leporidae. Vet. Parasitol. 2017, 243, 92-99. [CrossRef]

154. Ortega-García, M.V.; Salguero, F.J.; Rodríguez-Bertos, A.; Moreno, I.; García, N.; García-Seco, T.; Torre, G.L.; Domínguez, L.; Domínguez, M. A Pathological Study of Leishmania infantum Natural Infection in European Rabbits (Oryctolagus cuniculus) and Iberian Hares (Lepus granatensis). Trans. Emerg. Dis. 2019, 66, 2474-2781. [CrossRef]

155. Ebani, V.V.; Poli, A.; Rocchigiani, G.; Bertelloni, F.; Nardoni, S.; Papini, R.A.; Mancianti, F. Serological Survey on Some Pathogens in Wild Brown Hares (Lepus europaeus) in Central Italy. Asian Pac. J. Trop. Med. 2016, 9, 465-469. [CrossRef]

156. Rocchigiani, G.; Ebani, V.V.; Nardoni, S.; Bertelloni, F.; Bascherini, A.; Leoni, A.; Mancianti, F.; Poli, A. Molecular Survey on the Occurrence of Arthropod-Borne Pathogens in Wild Brown Hares (Lepus europaeus) from Central Italy. Infect. Genet. Evol. 2018, 59, 142-147. [CrossRef]

157. Chitimia, L.; Muñoz- García, C.I.; Sánchez-Velasco, D.; Lizana, V.; Del Río, L.; Murcia, L.; Fisa, R.; Rierad, C.; Giménez-Fonte, P.; Jiménez-Montalbán, P.; et al. Cryptic Leishmaniosis by Leishmania infantum, a Feature of Canines Only? A Study of Natural Infection in Wild Rabbits, Humans and Dogs in Southeastern Spain. Vet. Parasitol. 2011, 181, 12-16. [CrossRef]

158. Díaz-Sáez, V.; Merino-Espinosa, G.; Morales-Yuste, M.; Corpas-López, V.; Pratlong, F.; Morillas-Márquez, F.; Martín-Sánchez, J. High Rates of Leishmania infantum and Trypanosoma nabiasi Infection in Wild Rabbits (Oryctolagus cuniculus) in Sympatric and Syntrophic Conditions in an Endemic Canine Leishmaniasis Area: Epidemiological Consequences. Vet. Parasitol. 2014, 202, 119-127. [CrossRef]

159. Navea-Pérez, H.M.; Díaz- Sáez, V.; Corpas- López, V.; Merino- Espinosa, G.; Morillas- Márquez, F.; Martín- Sánchez, J. Leishmania infantum in Wild Rodents: Reservoirs or Just Irrelevant Incidental Hosts? Parasitol. Res. 2015, 114, 2363-2370. [CrossRef]

160. Millán, J. Molecular Investigation of Vector-Borne Parasites in Wild Micromammals, Barcelona (Spain). Parasitol. Res. 2018, 117, 3015-3018. [CrossRef] 
161. Pourmohammadi, B.; Mohammadi-Azni, S.; Kalantari, M. Natural Infection of Nesokia indica with Leishmania major and Leishmania infantum Parasites in Damghan City, Northern Iran. Acta Trop. 2017, 170, 134-139. [CrossRef]

162. Helhazar, M.; Leitão, J.; Duarte, A.; Tavares, L.; da Fonseca, I.P. Natural Infection of Synathropic Rodent Species Mus musculus and Rattus norvegicus by Leishmania infantum in Sesimbra and Sintra-Portugal. Parasit. Vectors 2013, 6, 1-6. [CrossRef]

163. Echchakery, M.; Chicharro, C.; Boussaa, S.; Nieto, J.; Carrillo, E.; Sheila, O.; Moreno, J.; Boumezzough, A. Molecular Detection of Leishmania infantum and Leishmania tropica in Rodent Species from Endemic Cutaneous Leishmaniasis Areas in Morocco. Parasit. Vectors 2017, 10, 1-8. [CrossRef]

164. Ibrahim, E.A.; Al-Zahrani, M.A.; Al-Tuwaigri, A.S.; Al-Shammary, F.J; Evans, D.A. Leishmania Infecting Man and Wild Animals in Saudi Arabia. 9. The Black Rat (Rattus rattus) a Probable Reservoir of Visceral Leishmaniasis in Gizan Province, South-West Saudi Arabia. Trans. R. Soc. Trop. Med. Hyg. 1992, 86, 513-514. Available online: https://academic.oup.com/trstmh/article/86/5 /513/1922532 (accessed on 25 February 2021). [CrossRef]

165. Zanet, S.; Sposimo, P.; Trisciuoglio, A.; Giannini, G.; Strumia, F.; Ferroglio, E. Epidemiology of Leishmania infantum, Toxoplasma gondii, and Neospora caninum in Rattus rattus in Absence of Domestic Reservoir and Definitive Hosts. Vet. Parasitol. 2014, 199, 247-249. [CrossRef]

166. Papadogiannakis, E.; Spanakos, G.; Kontos, V.; Menounos, P.G.; Tegos, N.; Vakalis, N. Molecular Detection of Leishmania infantum in Wild Rodents (Rattus norvegicus) in Greece. Zoonoses Public Health 2010, 57, 2009-2011. [CrossRef] [PubMed]

167. Pourmohammadi, B.; Motazedian, M.H.; Kalantari, M. Rodent Infection with Leishmania in a New Focus of Human Cutaneous Leishmaniasis, in Northern Iran. Ann. Trop. Med. Parasitol. 2008, 102, 127-133. [CrossRef] [PubMed]

168. Akhoundi, M.; Mohebali, M.; Asadi, M.; Mahmodi, M.R.; Amraei, K.; Mirzaei, A. Molecular Characterization of Leishmania spp. in Reservoir Hosts in Endemic Foci of Zoonotic Cutaneous Leishmaniasis in Iran. Folia Parasitol. 2013, 60, 218-224. [CrossRef] [PubMed]

169. Masoumeh, A.; Kourosh, A.; Mohsen, K.; Hossein, M.M.; Qasem, A.; Djaefar, M.F.M.; Esmaeil, N.M.; Tahereh, D. Laboratory Based Diagnosis of Leishmaniasis in Rodents as the Reservoir Hosts in Southern Iran, 2012. Asian Pac. J. Trop. Biomed. 2014, 4, S575-S580. [CrossRef]

170. Nezamzadeh-Ezhiyeh, H.; Mirhendi, H.; Jafari, R.; Veysi, A.; Rassi, Y.; Oshaghi, M.A.; Arandian, M.H.; Abdoli, H.; Bahrami, S.; Ramazani, A.R.Z.; et al. An Eco-Epidemiological Study on Zoonotic Cutaneous Leishmaniasis in Central Iran. Iran. J. Public Health 2021, 50, 350-359. [CrossRef]

171. Azizi, K.; Moemenbellah-Fard, M.D.; Fakoorziba, M.R.; Fekri, S. Gerbillus nanus (Rodentia: Muridae): A New Reservoir Host of Leishmania major. Ann. Trop. Med. Parasitol. 2011, 105, 431-437. [CrossRef]

172. Kassahun, A.; Sadlova, J.; Benda, P.; Kostalova, T.; Warburg, A.; Hailu, A.; Baneth, G.; Volf, P.; Votypka, J. Natural Infection of Bats with Leishmania in Ethiopia. Acta Trop. 2015, 150, 166-170. [CrossRef]

173. Rouhani, S.; Mirzaei, A.; Spotin, A.; Parvizi, P. Novel Identification of Leishmania major in Hemiechinus auritus and Molecular Detection of This Parasite in Meriones libycus from an Important Foci of Zoonotic Cutaneous Leishmaniasis in Iran. J. Infect. Public Health 2014, 7, 210-212. [CrossRef]

174. Pourmohammadi, B.; Mohammadi-Azni, S. Molecular Detection of Leishmania major in Hemiechinus auritus, A Potential Reservoir of Zoonotic Cutaneous Leishmaniasis in Damghan, Iran. J. Arthropod Borne Dis. 2019, 13, 334-343. [CrossRef]

175. Tomás-Pérez, M.; Khaldi, M.; Riera, C.; Mozo-León, D.; Ribas, A.; Hide, M.; Barech, G.; Benyettoub, M.; Seghirib, K.; Doudou, S.; et al. First Report of Natural Infection in Hedgehogs with Leishmania major, a Possible Reservoir of Zoonotic Cutaneous Leishmaniasis in Algeria. Acta Trop. 2014, 135, 44-49. [CrossRef]

176. Gicheru, M.M.; Jeneby, M.M.; Macharia, J.C.; Carlsson, H.E.; Suleman, M.A. Prevalence of Antibodies and Cell Mediated Immune Response against Leishmania major in Feral Nonhuman Primates from Kenya. Acta Trop. 2009, 109, 136-140. [CrossRef]

177. Moemenbellah-Fard, M.D.; Kalantari, M.; Rassi, Y.; Javadian, E. The PCR- Based Detection of Leishmania major Infections in Meriones libycus (Rodentia: Muridae) from Southern Iran. Ann. Trop. Med. Parasitol. 2003, 97, 865-873. [CrossRef]

178. Najafzadeh, N.; Sedaghat, M.M.; Sultan, S.S.; Spotin, A.; Zamani, A.; Taslimian, R.; Yaghoubinezhad, A.; Parvizi, P. The Existence of Only One Haplotype of Leishmania major in the Main and Potential Reservoir Hosts of Zoonotic Cutaneous Leishmaniasis Using Different Molecular Markers in a Focal Area in Iran. Revista Soc. Brasil. Med. Trop. 2014, 47, 599-606. [CrossRef]

179. Faiman, R.; Abbasi, I.; Jaffe, C.; Motro, Y.; Nasereddin, A.; Schnur, L.F.; Torem, M.; Pratlong, F.; Dedet, J.P.; Warburg, A. A Newly Emerged Cutaneous Leishmaniasis Focus in Northern Israel and Two New Reservoir Hosts of Leishmania major. PLoS Negl. Trop. Dis. 2013, 7, e2058. [CrossRef]

180. Kassahun, A.; Sadlova, J.; Dvorak, V.; Kostalova, T.; Rohousova, I.; Frynta, D.; Aghova, T.; Yasur-Landaud, D.; Lemma, W.; Hailu, A.; et al. Detection of Leishmania donovani and L. tropica in Ethiopian Wild Rodents. Acta Trop. 2015, 145, 39-44. [CrossRef]

181. Massamba, N.N.; Mutinga, M.J.; Kamau, C.C. Characterisation of Leishmania Isolates from Laikipia District, Kenya. Acta Trop. 1998, 71, 293-303. [CrossRef]

182. Doha, S.A.; Shehata, M.G.; Fahmy, A.R.; Samy, A.M. Natural and Experimental Evidence of Viscerotropic Infection Caused by Leishmania tropica from North Sinai, Egypt. J. Egypt. Soc. Parasitol. 2014, 44, 425-434. [CrossRef]

183. Mukhtar, M.M.; Sharief, A.H.; El Saffi, S.H.; Harith, A.E.; Higazzi, T.B.; Adam, A.M.; Abdalla, H.S. Detection of Antibodies to Leishmania donovani in Animals in a Kala-Azar Endemic Region in Eastern Sudan: A Preliminary Report. Trans. R. Soc. Trop. Med. Hyg. 2000, 94, 33-36. [CrossRef] 
184. Tsokana, C.N.; Sokos, C.; Giannakopoulos, A.; Mamuris, Z.; Birtsas, P.; Papaspyropoulos, K.; Valiakos, G.; Spyrou, V.; Lefkaditis, M.; Chatzopoulos, D.C.; et al. First Evidence of Leishmania Infection in European Brown Hare (Lepus europaeus) in Greece: GIS Analysis and Phylogenetic Position within the Leishmania spp. Parasitol. Res. 2016, 115, 313-321. [CrossRef] [PubMed]

185. Morsy, T.A.; Al-Dakhil, M.A.; El-Bahrawy, A.F. Natural Leishmania infection in sand cats captured in Riyadh district, Saudi Arabia. J. Egypt. Soc. Parasitol. 1999, 29, 69-74. [PubMed]

186. Morsy, T.A.; el Shazly, A.M.; el Kady, G.A.; Sabry, A.H.; Handousa, A.A.; Ragheb, D.A.; Kotb, M.M. Natural Leishmania infections in two stray dogs and two Gerbillus pyramidum in Dakahlia Governorate, Egypt. J. Egypt Soc. Parasitol. 1994, 24, 383-394. [PubMed] 